ERNEST ORLANDO LAWRENCE

BERKELEY NATIONAL LABORATORY

\title{
Public Health Benefits of End- Use Electrical Energy Efficiency in California: An Exploratory Study
}

Agnes B. Lobscheid

Thomas E. McKone

Environmental Energy

Technologies Division

June 2006

This work was supported by the California Energy Commission and the US Environmental Protection Agency through the U.S. Department of Energy under Contract No. DE-AC02$05 \mathrm{CH} 11231$. 


\section{Disclaimers}

This report was prepared as a result of work sponsored by the California Energy Commission (Energy Commission). It does not necessarily represent the views of the Energy Commission, its employees, or the State of California. The Energy Commission, the State of California, its employees, contractors, and subcontractors make no warrant, express or implied, and assume no legal liability for the information in this report; nor does any party represent that the use of this information will not infringe upon privately owned rights. This report has not been approved or disapproved by the Energy Commission, nor has the Energy Commission passed upon the accuracy or adequacy of this information in this report.

This document was prepared as an account of work sponsored by the United States Government. While this document is believed to contain correct information, neither the United States Government nor any agency thereof, nor The Regents of the University of California, nor any of their employees, makes any warranty, express or implied, or assumes any legal responsibility for the accuracy, completeness, or usefulness of any information, apparatus, product, or process disclosed, or represents that its use would not infringe privately owned rights. Reference herein to any specific commercial product, process, or service by its trade name, trademark, manufacturer, or otherwise, does not necessarily constitute or imply its endorsement, recommendation, or favoring by the United States Government or any agency thereof, or The Regents of the University of California. The views and opinions of authors expressed herein do not necessarily state or reflect those of the United States Government or any agency thereof, or The Regents of the University of California.

\section{Ernest Orlando Lawrence Berkeley National Laboratory is an equal opportunity employer.}




\title{
Public Health Benefits of End-Use Electrical Energy Efficiency in California: An Exploratory Study
}

\author{
Agnes B. Lobscheid ${ }^{1}$ and Thomas E. McKone ${ }^{1,2}$ \\ 1Environmental Energy Technologies Division \\ Lawrence Berkeley National Laboratory \\ Berkeley, CA 94720 \\ ${ }^{2}$ School of Public Health \\ University of California \\ Berkeley, CA 94720
}

Gina Barkalow, Commission Project Manager:

PIER Program Area: Energy Related Environmental Research

PIER Program Area Lead: ???

CIEE AWARD No. MEX0506 WA-MR035

Under CEC/CIEE Prime Contract No. 500-02-004

Publication number: $X X X-X X-X X X$

June 2006

Work supported by the California Energy Commission and the US Environmental Protection Agency and carried out at the Lawrence Berkeley National Laboratory through U.S. Department of Energy under Contract Grant No. DE-AC02-05CH11231. 


\section{Preface}

The Public Interest Energy Research (PIER) Program supports public interest energy research and development that will help improve the quality of life in California by bringing environmentally safe, affordable, and reliable energy services and products to the marketplace.

The PIER Program, managed by the California Energy Commission (Energy Commission) conducts public interest research, development, and demonstration (RD\&D) projects to benefit the electricity and natural gas ratepayers in California. The Energy Commission awards up to $\$ 62$ million annually in electricity-related RD\&D, and up to $\$ 12$ million annually for natural gas RD\&D.

The PIER program strives to conduct the most promising public interest energy research by partnering with $R D \& D$ organizations, including individuals, businesses, utilities, and public or private research institutions.

PIER funding efforts are focused on the following RD\&D program areas:

- Buildings End-Use Energy Efficiency

- Industrial/Agricultural/Water End-Use Energy Efficiency

- Renewable Energy Technologies

- Environmentally Preferred Advanced Generation

- Energy-Related Environmental Research

- Energy Systems Integration

Public Health Benefits of End-Use Electrical Energy Efficiency in California: An Exploratory Study is the final report for the Public Health Benefits of End-Use Electrical Energy Efficiency in California project (contract number 500-02-004) conducted by Lawrence Berkeley National Laboratory. The information from this project contributes to PIER's Energy-Related Environmental Research program.

For more information on the PIER Program, please visit the Energy Commission's Web site at www.energy.ca.gov/pier or contact the Energy Commission at (916) 654-5164. 


\section{Table of Contents}

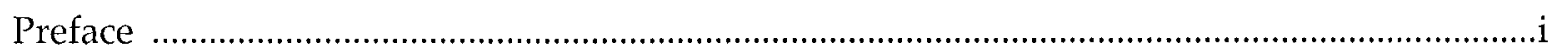

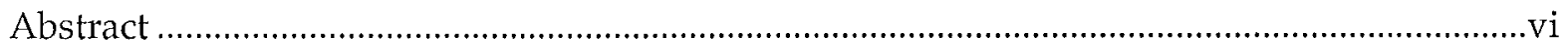

Executive Summary

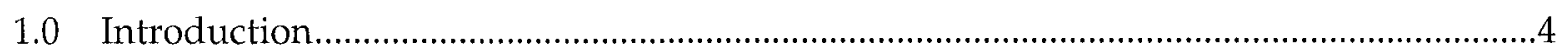

1.1. Background and Overview ..............................................................................

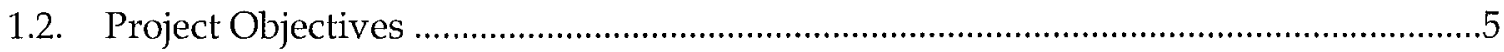

1.3. Report Organization ........................................................................................6

2.0 Project Approach and Methods ..................................................................................6

2.1. Scope of the Analysis ........................................................................................

2.1.1. Framework definition—concept and approach...................................................8

2.1.2. Portfolio of energy production technologies....................................................9

2.1.3. Energy end-use reduction technologies................................................................9

2.1.4. Pollutant categories and human exposure ………………………………….......9

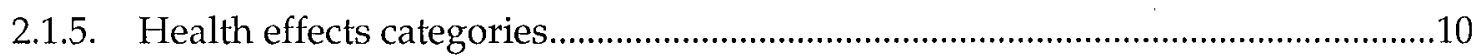

2.1.6. Boundaries for the time and spatial scale of health impacts................................10

2.2. Location and Relative Magnitude of Emissions ..........................................................10

2.3. Dispersion, Exposure and Intake of Emissions to Air................................................13

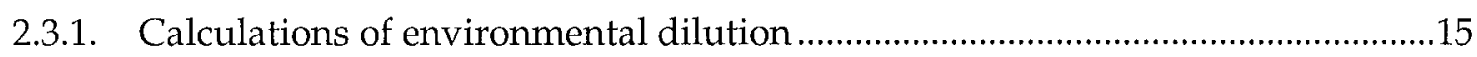

2.3.2. Human exposure and intake ..........................................................................16

2.4. Estimating and Expressing Disease Burden ................................................................17

2.4.1. The effect factor $\left(\mathrm{EF}_{\mathrm{x}}\right)$ for cancer ………...................................................18

2.4.2. The effect factor $\left(\mathrm{EF}_{\mathrm{x}}\right)$ for non-cancer effects ......................................................19

2.5. The Magnitude and Uncertainty of Any Added or Averted Disease Burden.............21

2.5.1. Energy and emissions reductions resulting from residential fiberglass

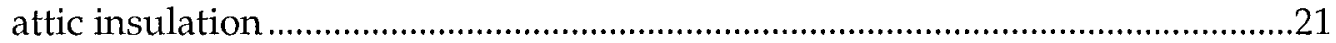

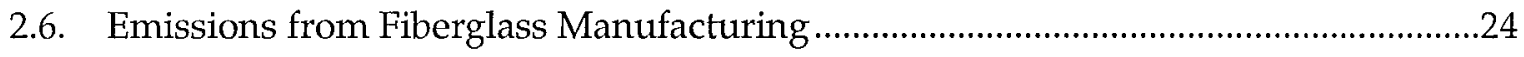

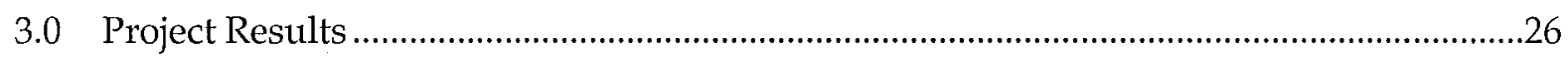

3.1. Magnitude and Location of Emissions......................................................................26

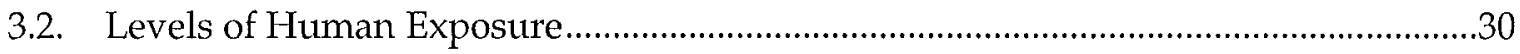

3.3. Results for the Disease Burden Calculations..................................................................31

3.3.1. Effect factors (EFx) for cancer and non-cancer diseases ........................................31

3.3.2. Human damage factors (HDFs) for cancer and non-cancer diseases...................33

3.4. Estimates of Disease Burden Added or Averted: Residential Attic

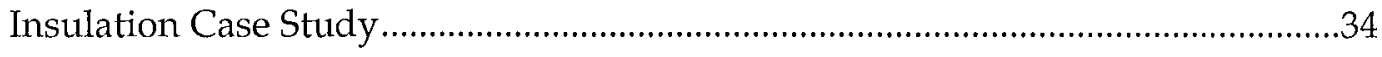

3.4.1. Energy savings and resulting emissions and disease burden reductions...........34 
3.4.2. Emissions and energy analysis for fiberglass insulation manufacturing...........38

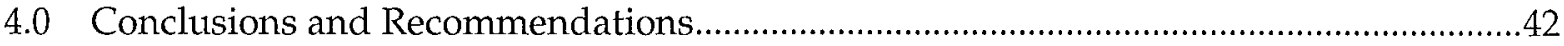

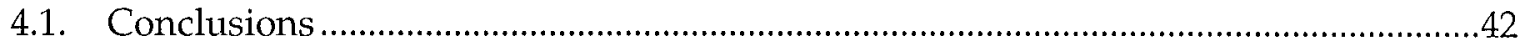

4.1.1. Providing a roadmap to organize a health benefits study for energy efficiency

4.1.2. Demonstrating use of life-cycle impact assessment tools to fill in this roadmap

4.1.3. Providing an informative case study to illustrate how one can construct and evaluate a health benefits study for energy efficiency improvements in California

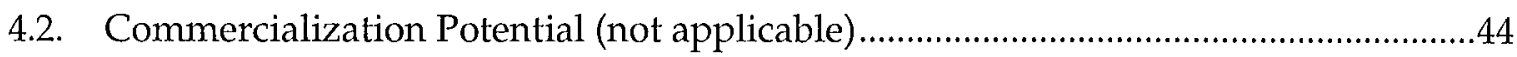

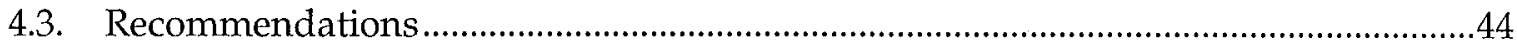

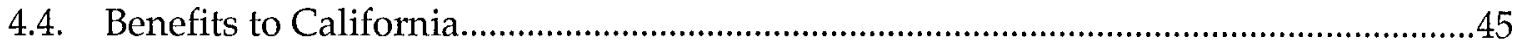

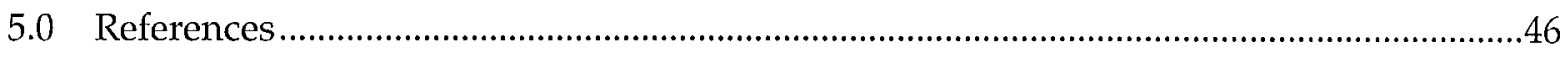

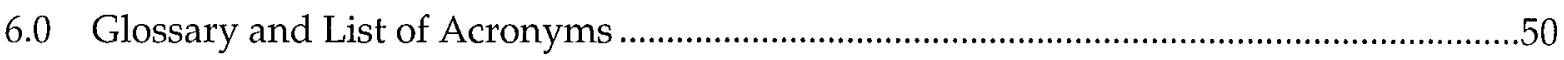

Appendix A: Tables of Data Used to Estimate Pollutant Emissions per MWe-y .....................54

Appendix B: Intermediate Results for the Individual Intake Fraction and Effect Factors Used to Calculate Human Damage Functions (HDFs)...

Attachment I: List of (A) Urban and (B) Rural Power Plants and Their Associated Fuel Type and Technology and Online MWe Sorted By County Of Location

\section{List of Figures}

Figure 1. Typical applications and phases of a life-cycle analysis (adapted from Pennington et al., 2004 and based on ISO 14040, 1997) ...................................... 5

Figure 2. The conceptual framework and key elements of this study ................................ 8

Figure 3. Fuel type contribution to total online-MWe (62,264 MWe) produced

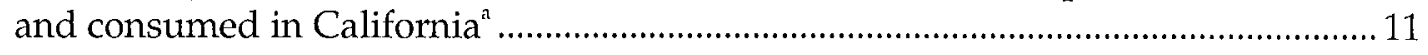

Figure 4. The elements of the CalTOX multimedia fate and exposure model .................. 14

Figure 5. Materials and processes involved in the manufacture of fiberglass

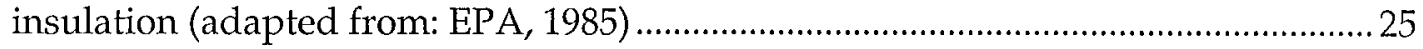

\section{List of Tables}

Table 1. Physical-chemical properties of pollutants included in this report ....................15

Table 2. The population and total area (land \& water) of the study regions ................... 16

Table 3. Assumptions and conversion factors used to calculate the cancer $\mathrm{EF}_{x} \ldots . . . . . . . . . .19$ 
Table 4. Distribution of attic (and cathedral ceiling for those housing units built after 1992) insulation R-values $\left[\mathrm{ft}^{2}-\mathrm{hr}{ }^{\circ} \mathrm{F} / \mathrm{Btu}\right.$ ] for electricity heated homes from the 2001 DEER study (Energy Commission, 2001)

Table 5: Median Area ${ }_{\text {roof }}\left[\mathrm{ft}^{2}\right]$ of single-family housing units in California from DEER 2001 (Energy Commission, 2001)

Table $6 . \Delta$ Energy associated with increased insulation per single-family home $[\mathrm{Btu} / \mathrm{yr}]$

Table 7. Distribution of electricity heated homes for the Western region of the US ${ }^{\mathrm{a}}$......... 23

Table 8. Emissions estimates [kg/MWe-y] from coal, natural gas, oil, and WTE primary fuel powered electricity generating plants in a) urban and b) rural regions of California .... 28

Table 9. Median values of the $i F i$ [-] for each pollutant in each region .............................. 31

Table 10. The EFx estimates for each pollutant …................................................................. 32

Table 11. Chemical specific HDFs (DALYs/kg emitted) for cancer, non-cancer and premature mortality health effects in the population of regions of California ...........33

Table 12. Ranges of total emission savings [kg] over 50-year assumed lifetime of fiberglass insulation in urban and rural regions [kg], respectively.

Table 13. DALYs saved per Mt insulation installed. Values shown represent the midpoint of the value range based on the range of emissions given in Table 12...... 37

Table 14. Estimated emissions from manufacturing 1.1 Mt of residential attic insulation compared to emissions eliminated by reduced electricity production over 50 years

Table 15. Summary of the Characteristic Travel Distance (CTD), area, population size and DALYs/Mt insulation manufactured. 


\section{Acknowledgements Page}

This work was supported by the California Energy Commission (Energy Commission) Public Interest Research Environmental Research Program (PIER). The authors are grateful to the Energy Commission for this research support. This work was also supported in part by the US Environmental Protection Agency National Exposure Research Laboratory through Interagency Agreement \#DW-89-93058201-1. All the work on this study and report was carried out at Lawrence Berkeley National Laboratory through the US Department of Energy under Contract Grant No. DE-AC02-05CH11231.

All spreadsheets used in this report are available upon request from the author(s).

\section{Citation}

Lobscheid, Agnes B. and Thomas E. McKone 2006. Public Health Benefits of End-Use Electrical Energy Efficiency in California: An Exploratory Study. Lawrence Berkeley National Laboratory report LBNL-59669. California Energy Commission, PIER. XXX-XX-XXX. 


\begin{abstract}
This study assesses for California how increasing end-use electrical energy efficiency from installing residential insulation impacts exposures and disease burden from power-plant pollutant emissions. Installation of fiberglass attic insulation in the nearly 3 million electricity-heated homes throughout California is used as a case study. The pollutants nitrous oxides (NOx), sulfur dioxide $\left(\mathrm{SO}_{2}\right)$, fine particulate matter (PM2.5), benzo(a)pyrene, benzene, and naphthalene are selected for the assessment. Exposure is characterized separately for rural and urban environments using the CalTOX model, which is a key input to the US Environmental Protection Agency (EPA) Tool for the Reduction and Assessment of Chemicals and other environmental Impacts (TRACI). The output of CalTOX provides for urban and rural populations emissions-to-intake factors, which are expressed as an individual intake fraction (iFi). The typical $i F i$ from power plant emissions are on the order of $10^{-13}$ ( $\mathrm{g}$ intake per $\mathrm{g}$ emitted) in urban and rural regions. The cumulative (rural and urban) product of emissions, population, and $i F i$ is combined with toxic effects factors to determine human damage factors (HDFs). HDF are expressed as disability adjusted life years (DALYs) per kilogram pollutant emitted. The HDF approach is applied to the insulation case study. Upgrading existing residential insulation to US Department of Energy (DOE) recommended levels eliminates over the assumed 50-year lifetime of the insulation an estimated 1000 DALYs from power-plant emissions per million tonne $(\mathrm{Mt})$ of insulation installed, mostly from the elimination of PM2.5 emissions. In comparison, the estimated burden from the manufacture of this insulation in DALYs per Mt is roughly four orders of magnitude lower than that avoided.
\end{abstract}





\section{Executive Summary}

\section{Introduction}

In 2004, more than 62 gigawatts (GW) of installed generating capacity produced electric energy for consumption in California. Methods of life-cycle impact assessment are applied in this study to assess for the California region how increasing energy efficiency from installing residential insulation impacts population exposures to air pollutants and the associated disease burden. For both the current mix of electrical energy producing technologies and for insulation manufacturing the locations, emissions, and disease burdens associated with insulating new and existing residences are considered.

\section{Purpose}

The purpose of this report is to confront the problem of quantifying both the public health hazards avoided and those substituted by increasing end-use efficiency of electricity use in California. The generation, transmission, and use of electricity have all been demonstrated to have adverse impacts on the environment. Increasing the efficiency of electricity use provides public health benefits by reducing emissions from fuel combustion on other energy system components. But efficiency gains have cost implications and their own set of potential health risks. There is clearly a need for consumers, businesses and decision makers to have better information on the relative health benefits of using energy more efficiently. But there is a need for research to move beyond a qualitative understanding of this issue by specifically quantifying the changes in both emissions and source-to-dose relationships for energy-related pollutants in a large and well-characterized market such as California.

\section{Objectives}

This report describes a definition study rather than a comprehensive life-cycle-assessment. In this context, the objectives of this project are to

- provide the roadmap to organize a health benefits study for energy efficiency;

- demonstrate the use of life-cycle impact assessment tools such as the US Environmental Protection Agency (EPA) TRACI/CalTOX system (Bare et al. 2002) to fill in this road map; and

- provide an informative case study to illustrate how one can construct and evaluate a health benefits study for a energy-efficiency improvements in California.

To meet these project objectives the research team employed standard life-cycle impact assessment (LCIA) methods that have been developed for evaluating and allocating the health and environmental impacts of energy technologies.

The key elements of the framework used to quantify life-cycle benefits and impacts of energy efficiency are the conceptual model; the computational models and how they are applied; and the sources, types, and values of data used as model inputs. The conceptual framework for allocating impacts is derived from the methods of life-cycle assessment and comparative risk assessment. US EPA and Energy Commission databases are used for determining emissions locations and magnitude. Exposure assessments are based on regional mass-balance models for 
criteria pollutants and regional multimedia fate models for hazardous air pollutants. Exposure is used to calculate intake, which is the basis for calculating disease burden. Disability adjusted life years (DALYs) provide the measure of disease burden in the comparative calculations. The subsections below provide details on how these elements are combined to evaluate energy efficiency. The focus is on technology-specific reductions in energy production in California corresponding to increasing insulation use and on how these reductions impact exposture to a portfolio of pollutants and reduce disease burden.

\section{Outcomes}

The study focuses on nitrous oxides (NOx), sulfur dioxide $\left(\mathrm{SO}_{2}\right)$, fine particulate matter (PM2.5), benzo(a)pyrene $(\mathrm{BaP})$, benzene, and naphthalene emissions from electricity generating plants in California. Exposure is characterized separately for rural and urban environments using the CalTOX model, which was employed for exposure assessment in the US EPA Tool for the Reduction and Assessment of Chemicals and other environmental Impacts (TRACI). The output from CalTOX provides for urban and rural populations emissions-to-intake factors, which are expressed as an individual intake fraction ( $i F i$ ). The cumulative (rural and urban) product of emissions, population, and $i F i$ is combined with toxic effects factors to determine human damage factors (HDFs). HDFs are expressed in disability adjusted life years (DALYs) per kilogram pollutant emitted. As a case study, this report quantifies changes in emissions and disease burden from installation of fiberglass attic insulation in the nearly 3 million electricityheated homes throughout California. These estimates are compared with disease burden from insulation manufacturing.

In urban regions of California, estimated typical individual intake fractions ( $i F i$ ) from power plant emissions are on the order of $10^{-13}\left(10^{-15}\right.$ for $\left.\mathrm{BaP}\right)$ in urban and rural regions. HDFs are dominated by premature mortality due to inhalation of PM2.5. HDFs for PM2.5 are roughly two orders of magnitude greater than inhalation exposure HDFs of the other five chemicals. Upgrading existing residential insulation to US Department of Energy (DOE) recommended levels eliminates over the estimated 50-year lifetime of the insulation approximately 1000 DALYs from power-plant emissions per million metric ton (Mt) of insulation installed, mostly from the elimination of PM2.5, and to a lesser extent NOx, emissions. In comparison, the manufacture of this insulation results in an estimated DALY per Mt that is roughly four orders of magnitude less than DALY avoided.

\section{Conclusions}

This study was successful in organizing the roadmap, data, and computational tools needed to assess both disease burden and health benefits from changes in energy production/consumption in California. The framing of this problem produced a repository of important information that will be useful for future comparative studies.

The researchers demonstrated the use of the and LCIA approach (TRACI/CalTOX) to determine how atmospheric emissions from electricity generating plants distribute in the environment and what populations are impacted. Overall, this study was successful in demonstrating the use of the TRACI/CalTOX-type framework in assessing pollutant emissions from electricity producing plants in California and the associated non-cancer and cancer disease burdens. 
The research team was able to construct a case study on the disease burdens averted due to the installation of approximately 1.1 million metric tons (Mt) of additional fiberglass attic insulation to reach DOE recommended levels, in California residences. Based on a 50-year assumed lifetime of the installed insulation, the avoided disease burden is approximately $10^{3}$ DALYs from power-plant emissions per $\mathrm{Mt}$ of insulation installed, mostly from the elimination of PM2.5 and to a lesser extent, NOx, emissions. When compared with the disease burden associated with the manufacture of this additional insulation, this study concludes that the DALYs per Mt of fiberglass insulation manufactured are four orders of magnitude less than those avoided.

\section{Recommendations}

The demonstrated utility of the LCIA framework for this study supports the need to evaluate the utility of this approach for other comparative health benefits studies. For example, this framework could also be used to assess the health benefits of fuel efficiency in the transportation sector.

The successful application of the TRACI-CalTOX-type of LCIA approach reveals the value of exploring whether and how this system could be applied to life-cycle studies of other energy production and energy efficiency technologies. Because existing LCIA methods have been developed for generic applications in life-cycle assessment, there is a need for research to expand, test, and support use of LCIA methods for comparative energy assessments in California.

Estimates of PM2.5 emissions and disease burden resulting from the manufacture of fiberglass insulation are so limited by uncertainty that a formal uncertainty analysis is needed to confirm conclusions about net health benefits of fiberglass insulation. Also, there is a need to consider a broader range of pollutant emissions, such as secondary aerosols, to assure that the PM2.5 is indeed the dominant contributor to disease burden.

\section{Benefits to California}

By including energy efficiency in comparative assessments for the current mix of energy technologies, the results and, in particular, the methods and data of this study, provide benefits to energy planning for California. Among the key benefits are:

- a potential tool for more informed decision making, based on the ability to aggregate and systematically evaluate information on potential environmental implications of alternative energy systems in the context of energy efficiency choices;

- an example of how this tool could be used to make decisions about improvement options for environmental quality by identifying optimal areas for reducing emissions/effluents, etc., on the basis of a comparative assessment of population disease burden associated with alternative supply and end-use management options; and

- $\quad$ an example of a more systematic approach for consideration of potential environmental and human health effects within the broader decision making process. 


\subsection{Introduction}

\subsection{Background and Overview}

Over recent decades, there has been extensive research to assess and compare the health risks of electrical energy production, but little effort to use these studies to determine the benefits of increasing end-use efficiency. No existing research has confronted the more specific question of the net public health benefits that accrue from increasing end-use efficiency in California or nationally. The goal of this exploratory project is to construct and evaluate a framework to calculate exposure reductions and the corresponding health benefits of increasing the end-use efficiency of electric energy in California. Examples of recent studies on the impacts of electricity production are the United Nations International Atomic Energy Agency (IAEA) study on the comparative health and environmental impacts of electricity generation systems (IAEA 1999) and the ExternE project (ExternE 2004). These studies take a fuel cycle approach, where impacts from fuel acquisition through waste disposal are estimated. The results provide useful insights and help promote further studies of impacts for many more technologies, sites and regions. However, because these comparative studies have to date excluded energy efficiency in the mix of technologies considered, there remains an important gap in the information available to policy makers for making well-informed decisions on energy choices for California. The focus of this study is emissions, environmental fate, human exposure and indicators of public health impact that apply to end-use efficiency.

The subject area of the report is the problem of quantifying both public health hazards and health risks avoided and those substituted by increasing end-use efficiency in California. The generation, transmission, and use of electricity have all been demonstrated to have adverse impacts on the environment (ORNL 1992; Ontario Hydro 1993; Dincer 1999; IAEA 1999; ExternE 2004; Bare et al. 2002). Increasing the efficiency of electricity use provides public health benefits by reducing emissions from fuel combustion on other energy system components. But efficiency gains have cost implications and their own set of potential health risks. There is clearly a need for consumers, businesses and decision makers to have better information on the relative health benefits of using energy more efficiently. Often end-use reduction technologies are evaluated only in terms of their relative cost savings based on the financial cost of equipment purchase and deployment. Environmental health scientists recognize that there are clear health benefits to reduced energy production. But there is a need for research to move beyond a qualitative understanding of this issue by specifically quantifying the changes in both emissions and source-to-dose relationships for energy-related pollutants in a large and well-characterized market such as California.

The research goal of this project is to quantify the energy-related environmental and public health benefits of efficiency using comparative health assessments. These assessments are designed to capture differences in impact among alternative production and efficiency technologies. By including energy efficiency in the mix of technologies encompassed in comparative assessments, the results of this study will contribute to more informed decision making. This exploratory study therefore provides more complete information on potential environmental and health implications of alternative energy systems in the context of energy efficiency choices. 


\subsection{Project Objectives}

Fuel cycles for energy production technologies can be characterized in terms of an upstream phase (resource extraction, component manufacture, fuel extraction, etc), a production phase (the actual electricity production facility), and a waste-management phase. Similarly, technologies for the efficient end-use of electricity have upstream, use, and disposal phases. To quantify cumulative health impacts for all these stages requires a life-cycle approach. Given the limited timeframe and budget for exploratory grants, this report describes a definition study rather than a comprehensive life-cycle assessment. In this context, the objectives of this project are to

- provide the roadmap to organize a health benefits study for energy efficiency;

- demonstrate the use of life-cycle impact assessment tools such as the US Environmental Protection Agency (EPA) TRACI/CalTOX system (Bare et al. 2002) to fill in this road map; and

- provide an informative case study to illustrate how one can construct and evaluate a health benefits study for a energy-efficiency improvements in California.

To meet these project objectives, the research team employed standard life-cycle impact assessment (LCIA) methods that have been developed for evaluating and allocating the health and environmental impacts of energy technologies (Guinée and Heijungs 1993; Guinée et al. 1996; Hertwich et al. 1998 and 2001; Hoffstetter 1998; IAEA 1999; Huijbregts et al. 2000; Bare et al. 2002; ExternE 2004). These methods provide a quantitative assessment of the contribution of life-cycle inventory data to environmental impacts, including human health effects. As shown by Figure 1, LCIA is a key phase in any LCA. Because this LCIA study primarily focuses on potential health benefits, it does not have an economic or epidemiological focus.

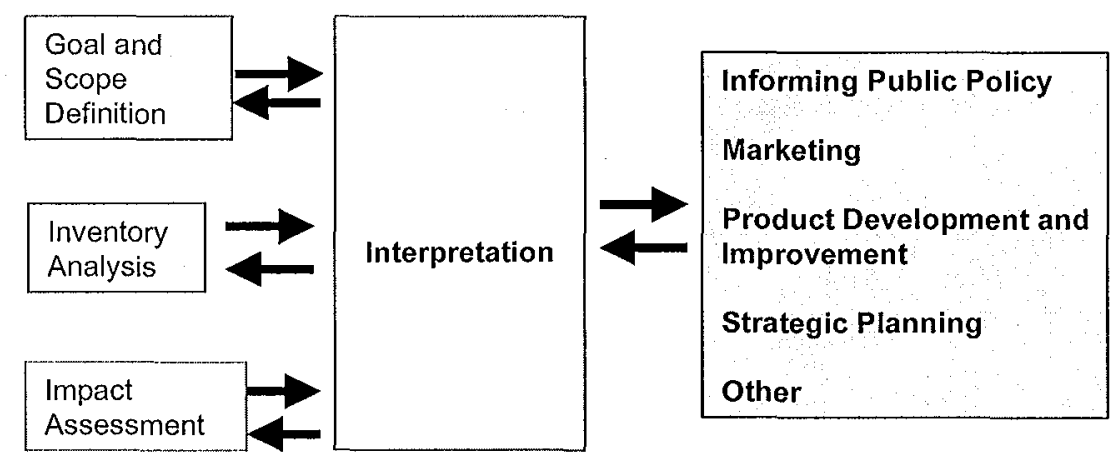

Figure 1. Typical applications and phases of a life-cycle analysis (adapted from Pennington et al., 2004 and based on ISO 14040, 1997) 
In the overall benefits framework, health impacts for energy production fuel cycles are based on criteria air pollutants, hazardous air pollutants, and hazardous substances released to water or transferred to disposal sites. Because these substances give rise to both cancer and non-cancer health endpoints, this exploratory assessment employs a single measure of potential harm by translating all health impacts into a single measure of disease burden-the disability or disease adjusted life years (i.e., DALYs). A substantial benefit to the DALY approach is that the chemicals with different health endpoints can be compared with each other on the same scale of health damage.

To demonstrate the framework for assessing net efficiency benefits for California, this report describes an initial case study based on particulate matter (PM 2.5), nitrous oxides (NOx), $\mathrm{SO}_{2}$, and toxic air pollutants (TAPs) including benzene and two polycyclic aromatic hydrocarbons, benzo(a)pyrene (BaP) and naphthalene. The current mix of energy technologies employed to produce electricity in California provides the emissions baseline used to estimate the net health benefits of increasing the use of insulation in California residences. In this exploratory, first-tier scoping study, the case study addresses the use of fiberglass attic insulation in existing residences. Therefore, the primary life-cycle inventory data used in this report is restricted to atmospheric emissions of selected pollutants from electricity generating power plants and from the manufacturing of energy efficient end-use technologies. This study does not focus on indoor sources of exposure or on the associated health effects from the indoor exposure to the chemicals considered in this study as releases to ambient air. Additionally, this research does not consider the economic impacts or other implications of installing the fiberglass insulation in California residences:

\subsection{Report Organization}

The remainder of this report is organized into three major sections-approach and methods, project results, and conclusions and recommendations. The approach and methods section provides information on the conceptual framework for the LCIA calculations, the models used, and the sources of data for these models. Emphasis here is placed on pollutant emissions, pollutant transport, human exposure, and resulting health effects from energy production in California. There is also an emphasis in the methods section on how one defines emissions and release locations for the current mix of technologies used to produce energy in California. Separate attention is given to insulation manufacture and use-with a focus on both energy saved and environmental emissions. Following the methods section is a results section that provides a detailed summary of quantitative findings along with an evaluation of these results. This is followed by a conclusions and recommendations section that summarizes for this study the key findings and the recommendations for energy technologies in California. This section also considers the benefits to California of implementing these recommendations.

\subsection{Project Approach and Methods}

The key elements of the framework used to quantify life-cycle benefits and impacts of energy efficiency are the conceptual model; the computational models and how they are applied; and the sources, types, and values of data used as model inputs. The conceptual framework for allocating impacts is derived from the methods of life-cycle assessment and comparative risk assessment. US EPA and Energy Commission databases are used for determining emissions locations and magnitude. Exposure assessments are based on the output from multimedia, 
multi-pathway models. These models typically estimate exposure based on the principle of mass balance, which matches emissions to both environmental dispersion and losses through transport and chemical transformation. LCIA relies primarily on regional multimedia models that are applicable over spatial scales from roughly 100 to $100,000 \mathrm{~km}^{2}$, to estimate human exposure to criteria and hazardous air pollutants. In LCIA it is commonplace to characterize exposures that are representative of an archetypal individual in a given region. Exposure is used to calculate human intake, which is the basis for calculating disease burdens in the population, through the use of the disability adjusted life years (DALYs) metric. DALYs provide the measure of disease burden in the comparative calculations. A substantial benefit to the DALY approach is that the chemicals can be compared with each other, on the same scale of harm.

The subsections below provide details on how these elements are combined to evaluate energy efficiency health benefits. The focus is on technology-specific reductions in energy production in California corresponding to increasing insulation use and on calculations of how the additional insulation changes exposures to a portfolio of pollutants and the corresponding reduction in disease burden.

\subsection{Scope of the Analysis}

In setting the scope of this study, the researchers had to select the portfolio of energy production technologies, the portfolio of demand-side reduction technologies, pollution categories and data, pollutant transport models, assumptions about human exposure to these pollutants, and the health effects categories. To facilitate these selections, the proposed framework is organized around an area of application. The area of application is population exposure to air pollutants attributable to both energy production and demand reduction technologies. The goal is to characterize disease burdens avoided as a result of reduced electricity generation, specifically due to the installation of fiberglass attic insulation in singlefamily residential units in California.

The scope of the analysis includes a definition of the conceptual framework; quantification of the amount of electricity generated for consumption in California; the location of this generating capacity; emissions associated with generating capacity; and allocation of the health benefits from emissions reductions attributable to greater energy efficiency. Figure 2 provides a summary illustration of both the scope and key elements of the approach. 


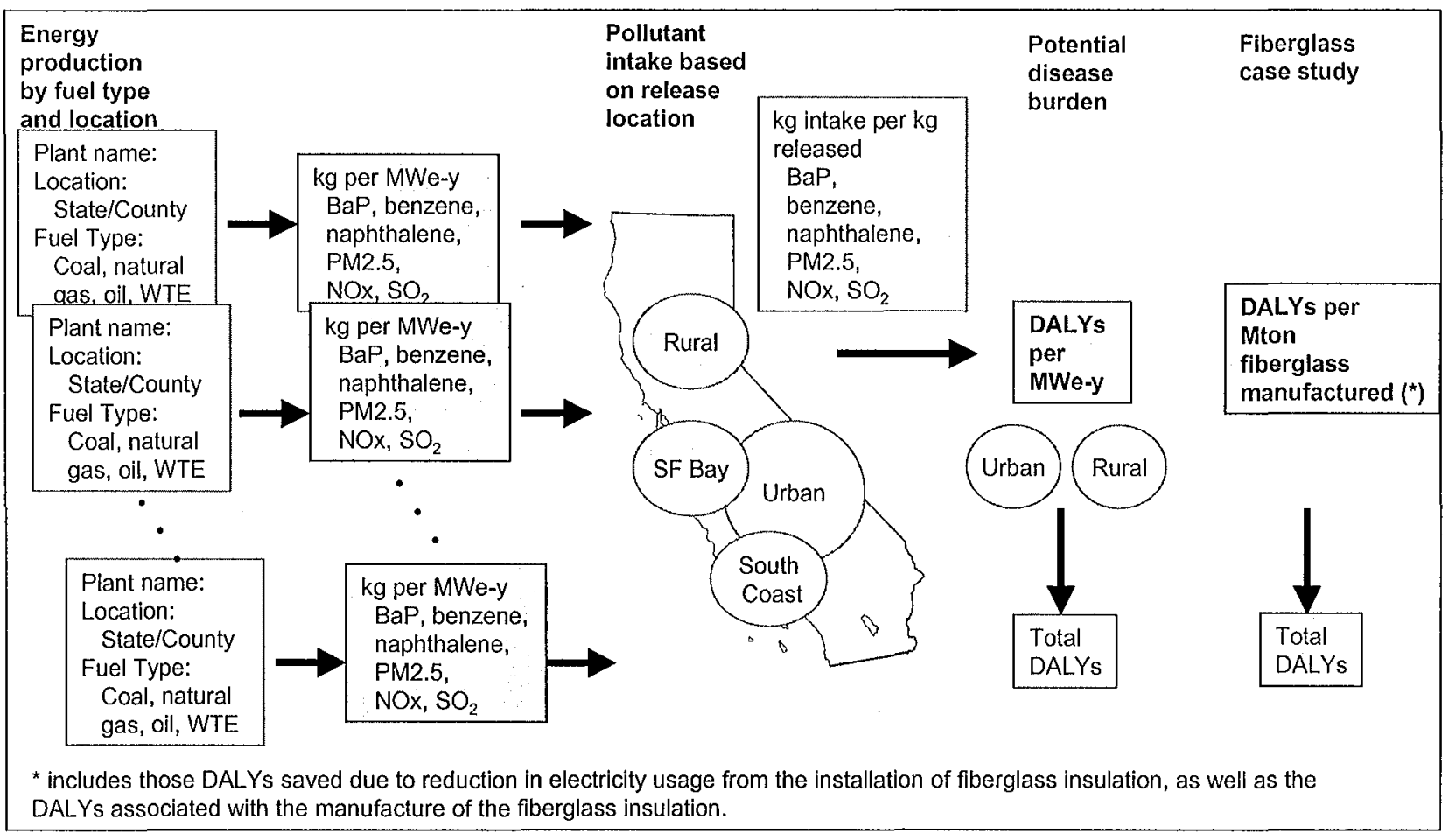

Figure 2. The conceptual framework and key elements of this study

\subsubsection{Framework definition-concept and approach}

Comparisons between impacts of various energy production systems and those associated with technologies to improve end-use efficiency must use a consistent framework for assessing environmental transport, human exposure, and health risks. The framework appropriate for addressing this comparison must address the following questions:

- What are the emission rates per unit (GWe-year) of electricity production?

- Which pollutants to select?

- Where are these emissions released?

- How are these emissions distributed in the environment?

- What populations are impacted and what is the level of human exposure?

- Where and how to set boundaries in terms of populations, time, and spatial scale for the assessment?

- What are the potential toxic effects of these exposures and the resulting health burden for California and other populations? 
- What are the uncertainties in defining and quantifying disease burden and how do we include the model evaluation process needed to identify and characterize these uncertainties?

These questions apply to both the technologies used to produce electrical energy and the technologies used to increase the efficiency of energy use. These questions require source-todose assessments that locate all points of chemical release to the environment, characterize mass-balance relationships, and track the contaminants through the entire environmental system to exposure of individuals or populations.

The key challenge for this task is to define a framework that includes sufficient fidelity to the real systems to make reliable classifications about the health impacts of energy systems but to avoid more detail than can be accommodated by existing theory and data. The researchers elected to use methods in the US EPA Tool for the Reduction and Assessment of Chemical and other environmental Impacts (TRACI) (Bare et al. 2002). In particular, this project relied on the CalTOX multimedia model, which is a key element of the TRACI system (Hertwich et al. 2001).

\subsubsection{Portfolio of energy production technologies}

Information available from the Energy Commission is used to establish the mix of energy technologies that provide the major fraction of electricity for California. Each technology is characterized according to (a) the type of fuel-technology combination (natural gas, coal, hydroelectric, nuclear, etc); (b) the location (county) of the production facilities within each type category; (c) the fraction of California energy provided at each combination of location/technology; and (d) pollutant emissions per megawatt electric (MWe) provided by that technology.

\subsubsection{Energy end-use reduction technologies}

The impacts of any technology used to reduce energy consumption must also be considered. For this project, the important attributes of an end-use technology include (a) type of technology (insulation, lighting, appliances, cool roofs, commercial HVAC, etc); (b) location of any production facilities linked to each technology; (c) fraction of California energy demand reduction provided at each combination of location/technology; and (d) energy save (MWeyears) for per functional unit (i.e., kilogram (kg) insulation) of technology used; and (e) pollutant emissions per functional unit (i.e., $\mathrm{kg}$ pollutant emitted per $\mathrm{kg}$ insulation manufactured). In this exploratory effort, the case study addresses the use of fiberglass attic insulation in existing residences.

\subsubsection{Pollutant categories and human exposure}

Quantifying human exposure begins with selecting pollutants that are important contributors to potential human health hazards. For atmospheric releases, the research team developed emissions estimates for coal, natural gas, oil, and waste-to-energy (WTE) fired electricity generating power plants located in California. Emissions factors were also developed for insulation manufacturing-expressing pollutant emissions per tonne of manufactured insulation. The resulting list of pollutants includes:

- $\mathrm{NOx}$ 
- $\mathrm{SO}_{2}$

- particulate matter with a $2.5 \mu \mathrm{m}$ or lower aerodynamic diameter (PM2.5)

- benzo(a)pyrene

- benzene

- naphthalene

The atmospheric emissions estimates were used to characterize exposure levels for different geographical population subgroups in California. For the case study here, the state was divided into urban and rural populations. Then the research team used fate and transport modeling to obtain generic urban and rural exposure factors (emission-to-intake factor) for each pollutant emission. Then power plant emissions were allocated to either an urban or rural population based on the location of the facility. The emission-to-intake factor expresses the ratio of the typical exposure within a defined population per unit mass emitted, that is $\mathrm{kg} / \mathrm{d}$ intake/person per $\mathrm{kg} / \mathrm{d}$ released. The CalTOX model, which provides fate and exposure factors for TRACI (Bare et al., 2002), was used to calculate this ratio, which is referred to as the individual intake fraction (iFi) (Bennett et al. 2002a).

\subsubsection{Health effects categories}

Disease burden estimates attributable to pollutant exposures were based on the human damage functions (HDFs) (Crettaz et al., 2002; Huijbregts et al., 2005). For each of the pollutants listed above, the HDF expresses the disability adjusted life years lost in the population for each increase of intake, that is DALYs per mg intake.

\subsubsection{Boundaries for the time and spatial scale of health impacts}

The atmospheric emissions estimates and resulting disease burden analysis of this study were allocated by dividing the state into urban and rural counties. There were also separate illustrative analyses of the San Francisco Bay Area (SFBA) air basin and South Coast air basin. The analysis was carried out county by county. The power plants were assigned to a county, and the exposure modeling was carried out under either an urban or rural scenario based on the population density of the county. A rural county has a population density of less than 35 persons $/ \mathrm{km}^{2}$ and any county above that density is urban (Lobscheid and McKone 2004). The SFBA air basin is compromised of nine counties, including Alameda, Contra Costa, Marin, Napa, San Francisco, San Mateo, Santa Clara, Solano, and Sonoma counties. The South Coast Air Basin is compromised of four counties including, Los Angeles, Orange, Riverside, and San Bernardino (only half of the latter two are actually in the South Coast Air Basin, but for the purposes of this study, information on the whole county is included).

\subsection{Location and Relative Magnitude of Emissions}

In order to characterize the impact of emissions reductions due to energy efficiency, this study required a method for allocating emissions changes among the large number of power plants that supply electrical energy in California. The approach used considers installed capacity as a means of ranking the emissions burden by geographic location. Installed capacity for each 
facility and emissions factors for the fuel and technology used in each facility provide the basis for this calculation. In 2004, there was a total of 62.3 gigawatts electric (GWe) of installed production capability that generated electrical energy for consumption in California (Energy Commission, 2004). This capacity was derived from a number of fuel sources. Based on primary fuel sources reported by the Energy Commission (2004), the percent contribution of each of the fuel sources to electricity generation capacity in California is shown in Figure 3 . This figure reveals that half of the electricity capacity in California is from natural gas technologies. Although $3771 \mathrm{MWe}$ (or $6 \%$ ) of electricity generation capacity comes from coal-fired power plants (including coal plants that burn, as their primary fuel, lignite, and petroleum coke and/or crude oil), $86 \%$ of this generation capacity is outside of California, i.e., $43 \%$ in Utah (Intermountain 1\&2) and 43\% in Nevada (Mohave Generating Station, bordering California, in Clark County). Of the remaining $13 \%$ of coal derived generating capacity, close to half (47\%) is generated from coal plants that burn coal (bituminous, sub-bituminous, and lignite) exclusively. The other half use coal alternatives such as petroleum coke and/or crude oil within the state of California (amounting to less than $0.5 \%$ of the total MWe online generated in California). The allocations in Figure 3 are based on the assumption that the same efficiencies apply to all distribution systems upstream of the production plant. This study characterizes the emissions resulting from electrical energy power production within California for use in California. In addition, this study includes the emissions from the Mohave Generating Station in Clark County, Nevada because of its close proximity to the California border and large contribution of energy to California.

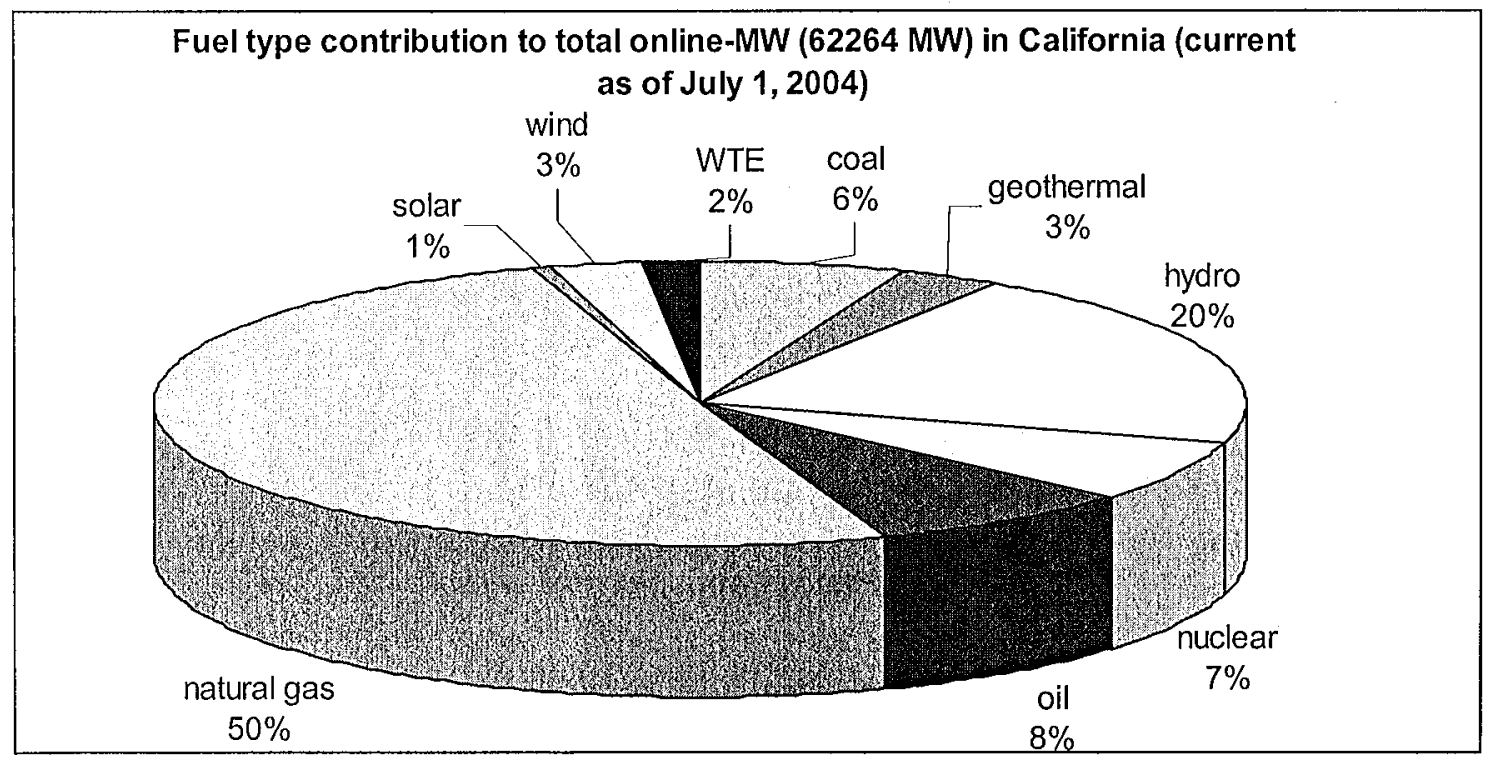

\section{Figure 3. Fuel type contribution to total online-MWe $(62,264 \mathrm{MWe})$ produced and consumed in California ${ }^{a}$}

"An exception to the production in California is the Mohave coal-fired power plants located in Clark County Nevada, bordering California, and operated by Southern California Edison. 
To characterize the allocation of emissions avoided due to efficiency-driven reductions in electrical power generation in California, the following two databases were combined:

1. The Energy Commission's (2004) database that includes all power plants in California that are one-tenth (0.1) megawatt capacity or larger. This database provides the following information for each plant: the plant name, county of location, owner, operator, the facility type (coal, oil, natural gas, or waste-to-energy, or WTE), the general fuel, primary fuel, and the technology employed to generate the reported online MWe for each plant. This information is current as of July 1,2004. Attachment I to this report provides the full list of plants considered for this study, along with county location, whether or not cogeneration technologies are used, the MWe online, and the classification of the plant's location as "urban" or "rural."

2. Chemical-specific emission factors (EFs) from the US EPA's AP-42 report (EPA 1995-2000). These data provide consistent, typical and transparent emission factors from oil and natural gas-fired plants, coal-fired plants as well as those plants burning waste-toenergy (WTE) fuels, such as agricultural and wood waste, landfill gas, and municipal solid waste and electricity generated from natural gas at redeveloped sites that have had the presence or potential presence of a toxic contaminant, that is Brownfields (developed sites) and Greenfields (undeveloped sites).

The data sets above were used to develop an emissions factor for each generating facility. The primary, as opposed to general, fuel use reported in the Energy Commission's database (2004) was used to generate emissions estimates. In the cases where more than one primary fuel was listed, it was assumed that there is an equal contribution from each fuel type to the total MWe capacity. Emission estimates [kg/(MWe-y)] for each chemical $i$ and plant $j$ are based on the following equation:

$$
\text { Emissions }_{i, j}=\left(\frac{M W t}{M W e}\right)_{j} \times \frac{E F_{i, j}}{H V_{f u e l}} \times C F_{f u e l} C F_{1} \times C F_{2} \times C F_{3}
$$

where,

$i$ designates the pollutant of interest;

$j$ designates the plant generating electricity from a specific fuel-technology combination;

$(\mathrm{MWt} / \mathrm{MWe})_{\mathrm{j}}$ is thermal output (MW) of plant $\mathrm{j}$ divided by its electrical output (MW) and equal to $1 / \eta_{e^{\prime}}$ with $\eta_{e}$ equal to the efficiency of plant $j$. Values for $\eta_{e}$ are provided in Appendix A, Table A-1. This analysis did not distinguish between the $\eta_{\mathrm{e}}$ of the lower heating value (LHV) or higher heating value (HHV) of the fuel. In general, $\eta_{e}$ values based on HHV were approximately 5-10\% higher than LHV (EPA 2001). In addition, unless otherwise noted, efficiencies were the electrical, not thermal, efficiency;

$\mathrm{EF}_{i, \mathrm{j}}$ is the chemical specific emission factor for chemical $i$ from plant type $j, \mathrm{~kg}$ pollutant unit quantity of fuel consumed. Table A-2(a-f) in Appendix A, lists $\mathrm{EF}_{\mathrm{i}, \mathrm{s}} \mathrm{s}$, (in $\mathrm{lb} /$ ton coal, $\mathrm{lb} / 1000$ gal oil and $\mathrm{lb} / 10^{6} \mathrm{scf}$ (standard cubic feet of gas) along with their EF rating (A$\mathrm{E}$; for details on the ratings see the introduction in $\mathrm{AP} 42$, 
http://www.epa.gov/ttn/chief/ap42/c00s00.pdf). For coal $\mathrm{EF}_{\mathrm{i}, \mathrm{j}}$ we used the average of the bituminous and sub-bituminous EF reported;

$\mathrm{HV}_{\text {fuel }}$ is the heating value of the specific fuel, expressed as Btu/lb coal, Btu/gal oil, Btu/scf natural gas, Btu/scf digester gas, or Btu/scf landfill gas. HVs are given in Appendix A, Table A-3;

$\mathrm{CF}_{\text {fuel }}$ is the conversion factor for fuels $\left(5 \times 10^{-4}\right.$ ton per $\mathrm{lb}$ of coal, $10^{-3} \mathrm{lb} / \mathrm{gal}$ per $\mathrm{lb} / 1000 \mathrm{gal}$ for oil, and $10^{-6} \mathrm{lb} / \mathrm{scf}$ per $\mathrm{lb} / 10^{6} \mathrm{scf}$ for gas).

$\mathrm{CF}_{1}$ is the conversion factor for MWe to Btu $\left(3.413 \times 10^{6} \mathrm{Btu} / \mathrm{h}\right.$ per MWe);

$\mathrm{CF}_{2}$ is the conversion factor for hours to years $(8760 \mathrm{~h} / \mathrm{y})$; and

$\mathrm{CF}_{3}$ is the conversion factor for $\mathrm{lb}$ pollutant to $\mathrm{kg}$ pollutant $(0.455 \mathrm{~kg} / \mathrm{lb})$.

Because the Energy Commission power plant database does not distinguish between bituminous coal and sub-bituminous coal, emission estimates were either based on an average EF value from the reported EFs from each fuel, where available in the AP 42, or the bituminous EFs. Furthermore, because $\mathrm{EF}_{\mathrm{i}, \mathrm{j}} \mathrm{s}$ relevant to petroleum coke and crude oil were not available, the $\mathrm{EF}_{\mathrm{i}, \mathrm{j}}$ for coal and the $\eta_{\mathrm{e}}$ of coal plants was applied to these fuel sources.

In those cases where two or more conversion technologies were reported, e.g., steam and gas turbine, it was assumed that an equal portion of the MWt output was generated from each, based on available $\mathrm{EF}_{\mathrm{i},{ }^{\prime}}$. With respect to $\mathrm{EFs}$ from natural-gas fired plants, where the technology of the power plants was not reported, steam turbine technology was assumed (these emit less chemicals than the stationary gas turbine plants).

For certain fuel-technology combinations, $\mathrm{EF}_{\mathrm{i}, \mathrm{j}}$ values were not available in the AP 42 . These included plants relying on enhanced oil recovery (EOR), and $\mathrm{NOx}$ and $\mathrm{SO}_{2}$ from digester gas technologies and $\mathrm{NOx}, \mathrm{SO}_{2}$, and benzene from landfill gas fuel technologies. Estimated emissions of these fuel-technology combinations were not accounted for in this report.

\subsection{Dispersion, Exposure and Intake of Emissions to Air}

In this study, the CalTOX model was used to characterize the transport, fate, exposure, and uptake for each pollutant released to the atmosphere of either urban or rural environments from electricity generating facilities used to provide energy for California. This approach was also used to assess impacts from insulation manufacturing. This exposure assessment translates emissions to intake for the populations proximate to electrical generating stations. Rather than a site-specific assessment for each power plant, generic urban and rural environments were used. This study made use of CalTOX version 4.4 (http:/ / eetd.lbl.gov/ied/era/), which was developed at the University of California, Berkeley, and provides fate and exposure assessments for TRACI (Bare et al., 2002). As illustrated in Figure 4, CalTOX is a multimedia, multi-pathway exposure model that tracks the dispersion and dilution of pollutants emitted to air, water, and/or soil. CalTOX has been widely used in the past for chemical classification and multimedia risk assessment. The parameters in the version of CalTOX used in this study have been validated in numerous studies and CalTOX itself has been evaluated using empirical data in field case studies for various chemicals, including BaP (Lobscheid and McKone, 2004). 


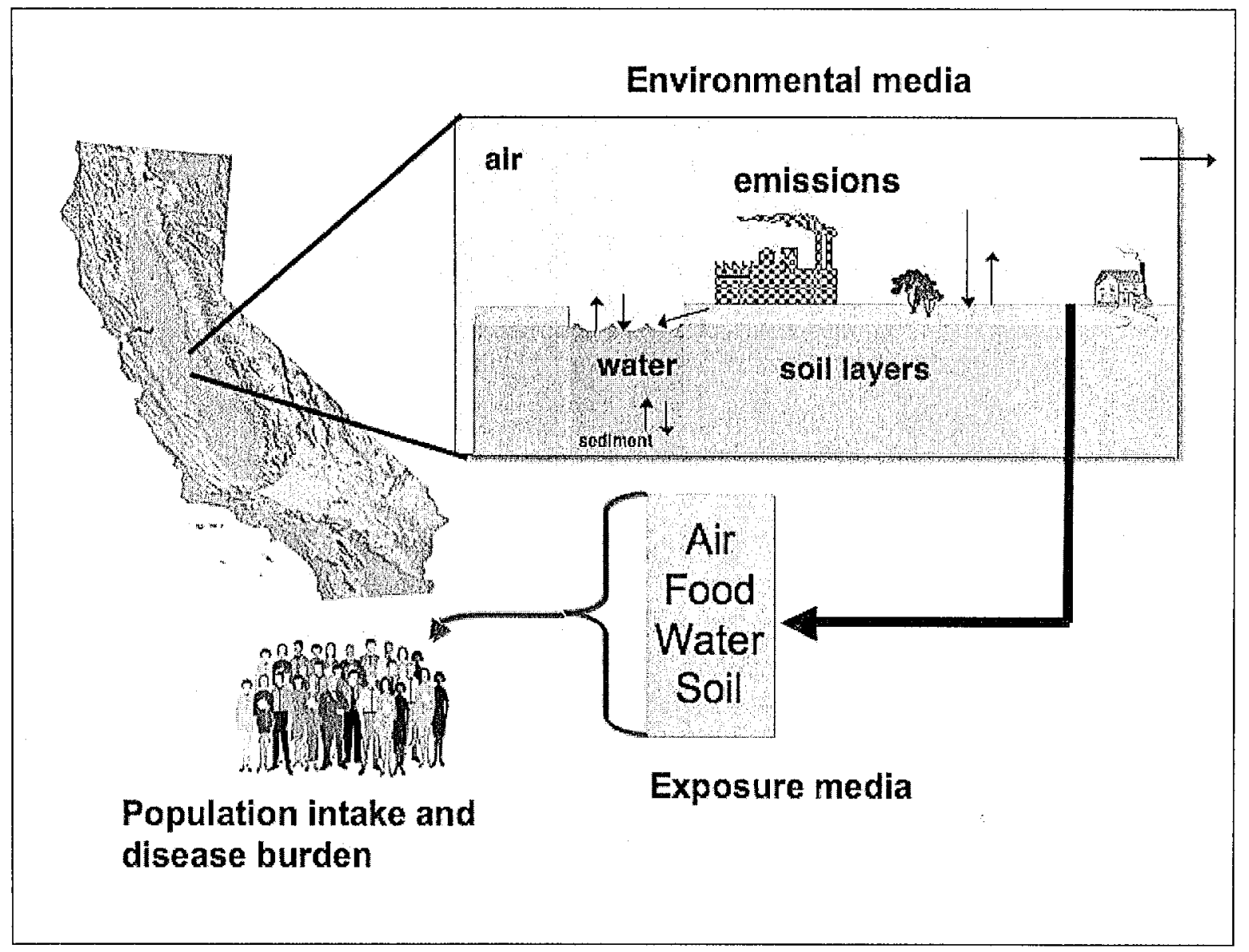

Figure 4. The elements of the CalTOX multimedia fate and exposure model

In general, multimedia fate and exposure models synthesize information about partitioning, reaction, and intermedia-transport properties of a chemical in a representative or generic environment with information about the typical individuals exposed. This information is used to assess impacts, such as health risk (McKone and MacLeod, 2004). In these models, the environment is treated as a set of compartments that are homogeneous subsystems exchanging water, nutrients, and chemical contaminants with other adjacent compartments. There are two basic features that make compartment models suitable for an integrated model of transport and transformation in multimedia environments: (a) each compartment forms a unit in which one can balance gains and losses attributable to air emissions, transfers to and from other compartments, and chemical transformations and (b) each compartment forms a unit in which chemical partitioning can be evaluated against equilibrium criteria. A cumulative multipathway exposure assessment for humans relates contaminant concentrations in multiple environmental media to concentrations in the media with which a human population has contact (for example; personal air, tap water, foods, household dusts, and soils). The potential for harm is assessed either as the average daily intake or uptake rate or as time-averaged contact concentration. Multimedia contaminant fate and exposure models have been useful to 
decision makers because these models provide an appropriate quantitative framework to evaluate our understanding of the complex interactions between chemicals and the environment. The greatest challenge for multimedia models is to provide useful information without creating overwhelming demands for input data and producing outputs that cannot be evaluated.

In the CalTOX model, the fate of a chemical emitted to the environment depends, among other factors, on its physical-chemical properties. Table 1 summarizes physical-chemical properties of the six pollutants that are the subject of this study. These properties include the molecular weight (MW), octanol-water partition coefficient $\left(\mathrm{K}_{\mathrm{ow}}\right)$, which is the lipid-to-water-solubility ratio, vapor pressure $\left(\mathrm{P}_{\text {vap }}\right)$, water solubility $\left(\mathrm{S}_{\text {water }}\right)$, and diffusion constants in air and water $\left(\mathrm{D}_{\text {air }}\right.$ and $\mathrm{D}_{\text {water }}$ respectively).

Table 1. Physical-chemical properties of pollutants included in this report

\begin{tabular}{|l|c|c|c|c|c|c|}
\hline Chemical & $\begin{array}{c}\mathrm{MW} \\
{[\mathrm{g} / \mathrm{mol}]}\end{array}$ & $\mathrm{K}_{\text {ow }}$ & $\mathrm{P}_{\text {vap }}[\mathrm{Pa}]$ & $\begin{array}{c}\mathrm{S}_{\text {water }} \\
{\left[\mathrm{mol} / \mathrm{m}^{3}\right]}\end{array}$ & $\begin{array}{c}\mathrm{D}_{\text {air }} \\
{\left[\mathrm{m}^{2} / \mathrm{d}\right]}\end{array}$ & $\begin{array}{c}\mathrm{D}_{\text {water }} \\
{\left[\mathrm{m}^{2} / \mathrm{d}\right]}\end{array}$ \\
\hline Benzene & 78.1 & 151 & $1.3 \times 10^{4}$ & 22.5 & 0.76 & $9.6 \times 10^{-5}$ \\
\hline Benzo(a)pyrene & 252 & $2.2 \times 10^{6}$ & $7.1 \times 10^{-7}$ & $1.0 \times 10^{-5}$ & 0.44 & $5.3 \times 10^{-5}$ \\
\hline Naphthalene & 128 & $2.39 \times 10^{3}$ & 12.9 & $2.4 \times 10^{-1}$ & 0.51 & $7.4 \times 10^{-5}$ \\
\hline $\mathrm{NO}_{x}{ }^{a}$ & 46 & $2.63 \times 10^{-1}$ & $1.0 \times 10^{5}$ & $2.2 \times 10^{4}$ & 0.61 & $6.9 \times 10^{-5}$ \\
\hline $\mathrm{SO}_{2}$ & 64 & $6.31 \times 10^{-3}$ & $1.0 \times 10^{5}$ & $1.7 \times 10^{3}$ & 0.61 & $6.9 \times 10^{-5}$ \\
\hline $\mathrm{PM}_{2.5}{ }^{\mathrm{b}}$ & 400 & 0 & 0 & 1 & 0.64 & $1.3 \times 10^{-4}$ \\
\hline
\end{tabular}

"Assumes physical-chemical properties of $\mathrm{NO}_{2}$

${ }^{\mathrm{b}}$ In addition to the listed assumptions in this table, separate analyses assuming the partition coefficients in the ground soil layer (Kd_s), vadose zone layer (Kd_v), aquifer layer (Kd_q) and in surface water sediments (Kd_d) are $10^{6}$ and $10^{7}$ were run.

\subsubsection{Calculations of environmental dilution}

The generic and modular format of the comparative assessment here requires that the dilution calculation provide a dilution factor that expresses the ratio of the long-term average concentration to the emission, $\left[\left(\mathrm{mg} / \mathrm{m}^{3}\right) /(\mathrm{kg} / \mathrm{y})\right.$. The multimedia fate and exposure model CalTOX was configured to calculate dilution factors for power plants located in each of the four regions listed in Table 2.

As is commonplace in LCIA, the researchers assigned releases to generic landscapes that represent archetypal regions but do not necessarily replicate any specific region. In this approach, environmental concentrations were characterized for six cases: (1) the total land area of the urban counties of California, (2) the total land area of the urban counties of California that have at least one electricity generating station, (3) the total land area of the rural counties of California, (4) the total land area of the rural counties of California that have at least one electricity generating station, (5) the South Coast air basin, and (6) the SFBA air basin. Dividing 
California into these six regions provided a process for assessing sensitivity of the results to how the emissions are allocated.

Table 2. The population and total area (land \& water) of the study regions

\begin{tabular}{|l|c|c|c|c|}
\hline Region & \multicolumn{2}{|c|}{ Total Area $\left[\mathrm{m}^{2}\right]$} & \multicolumn{2}{c|}{ Population } \\
\hline & $\begin{array}{c}\text { Counties } \\
\text { with power } \\
\text { plants }\end{array}$ & All counties & $\begin{array}{c}\text { Counties with } \\
\text { power plants }\end{array}$ & All counties \\
\hline Urban area & $1.9 \times 10^{11}$ & $2.0 \times 10^{11}$ & $3.3 \times 10^{7}$ & $3.3 \times 10^{7}$ \\
\hline Rural area & $1.2 \times 10^{11}$ & $2.2 \times 10^{11}$ & $2.2 \times 10^{6}$ & $2.6 \times 10^{6}$ \\
\hline South Coast air basin & & $8.5 \times 10^{11}$ & & $1.7 \times 10^{7}$ \\
\hline SFBA air basin & & $2.1 \times 10^{11}$ & & $7.0 \times 10^{6}$ \\
\hline
\end{tabular}

\subsubsection{Human exposure and intake}

To make the link from emission to intake, the "intake fraction," or iF concept, was applied (Bennett et al., 2002a, 2002b). Intake fraction is the fraction of material released from a source that is eventually inhaled or ingested by the human population in a defined geographic region. For environmental contaminants, the $\mathrm{iF}$ is the simplest possible expression of the source-tointake relationship, which is often a complicated function of the attributes of the chemical, the environment, and the population. Bennett et al. (2002a) have suggested a standard formalism for expressing the concept. Here, the individual intake fraction $i F i$ is employed. This is the intake fraction for a single representative individual within a defined region. The link between source emissions and intake is the product of the dilution factor obtained and the intake factor that expresses the contact a representative individual has with a diluted concentration in air, water, soil, etc.

The CalTOX model quantifies the source-to-exposure relationship for a system comprised of a pollutant defined by its chemical properties and release scenario, the environment within which it disperses, and the potentially exposed population. The nature and extent of multimedia exposures depends largely on human factors and the concentrations of a chemical substance in the contact media. Human factors include all behavioral, sociological, and physiological characteristics of an individual that directly or indirectly affect his or her contact with the substances of concern. Important factors in this regard are contact rates with air, water, food, soils, drugs, etc. Activity patterns, which are defined by an individual's allocation of time spent at different activities and locations, are also significant because they directly affect the magnitude of inhalation exposures to substances present in different indoor and outdoor environments.

The exposure models in CalTOX encompass twenty-three exposure pathways that relate contaminant concentrations in the multimedia model compartments to concentrations in media 
with which the human population has contact (i.e., personal air, tap water, foods, household dusts, soils, etc.). Average daily pollutant intake is calculated as the product of the exposure concentrations in these media and an intake factor for inhalation and ingestion that relates the concentration intake for a typical member of the population. For PM2.5 only, inhalation exposures were considered; for the other pollutants in this case study, multiple routes of exposure were allowed.

\subsection{Estimating and Expressing Disease Burden}

Disease burden is a metric that reflects the total amount of healthy life lost within a population due to all diseases found in that population. The calculation of disease burden attributable to pollutant exposures makes use of metrics that have been developed for LCIA, i.e., the human damage functions (HDFs). HDFs express the likelihood of a health consequence (e.g., cancer and/or non-cancer disease burden) resulting from the emission of a particular pollutant (Crettaz et al. 2002). The units of the HDF are effective years of life lost per $\mathrm{kg}$ pollutant emitted. Huijbregts et al. (2005) refer to HDFs as characterization factors $\left(\mathrm{CF}_{\mathrm{x}}\right)$. The general approach for calculating an HDF for a substance $x$, is:

$$
H D F_{x}=E F_{x} \times F F_{x}
$$

$\mathrm{EF}_{\mathrm{x}}$ is a severity-based effect factor characterizing both the potential disease burden associated with a lifetime exposure to chemical $x$, expressed as an equivalent loss of years [i.e., statistical years lost per $\mathrm{mg}$ intake of $\mathrm{x}] . \mathrm{FF}_{\mathrm{x}}$ is the fate factor, or the population intake per unit of emission. The $\mathrm{FF}_{\mathrm{x}}[\mathrm{kg}$ (intake)/y per $\mathrm{kg}$ (emission)/y] is equal to the $i F i$, multiplied by the population from Table 2 for which that $i F i$ applies. The $i F i$ is discussed in the previous section. The effect factor requires consideration of the type of disease, the probability of having that disease following exposure, and the measure of severity of the disease in terms of the equivalent years of life lost as a result of having that disease. In the paragraphs below, this process is reviewed for two major disease categories - cancer and non-cancer diseases. It is important to note here that cancer and non-cancer endpoints were explicitly evaluated for each chemical with the exception of PM2.5. This is because PM2.5 has reliable premature-mortality health data available that incorporates both non-cancer and cancer health endpoints. Therefore PM2.5 was not evaluated separately for these health endpoints. Furthermore, because morbidity endpoints, such as cardiovascular disease and respiratory function, attributable to outdoor air PM2.5 exposures tend to be available only for susceptible populations, such as Medicare enrollees (Dominici et al., 2006), this report focuses on the mortality endpoints. The methodology for PM2.5 is presented following the non-cancer and cancer health endpoint methodologies. 


\subsubsection{The effect factor $\left(E F_{x}\right)$ for cancer}

Both Crettaz et al. (2002) and Huijbregts et al. (2005) have proposed methods to determine $\mathrm{EF}_{\mathrm{x}}$ for cancer. Crettaz et al. (2002) propose:

$$
E F_{x}(\text { cancer })=\beta_{E D 10-x} \times D A L Y p
$$

$\beta_{\text {EDI0. }}$ is the linear low dose response slope factor [individual lifetime risk of cancer per $(\mathrm{mg} / \mathrm{kg}$ BW-day) intake] for chemical $x$, inducing a response over background of $10 \%$ for humans. It is obtained from the dose that gives $10 \%$ of a population a response (i.e., cancer) the ED10 $0_{x, 1}$ $\left[\mathrm{mg} / \mathrm{kg} \mathrm{BW} /\right.$ day]. So $\beta_{E D 10, x}=0.1 / E D 10_{x, h} D A L Y_{p}$ is the sum of years of life lost due to death and disability from the cancer caused by $x$ [years lost/incidence]. The default $D A L Y_{p}$ for carcinogens is $6.7 \mathrm{y}$. Because $\mathrm{BaP}$ and benzene are also associated with specific cancers, lung cancer and leukemia, respectively, the specific DALYp were also used. Therefore, in addition to the default DALYp of $6.7 \mathrm{y}, 13.0$ and $14.6 \mathrm{y}$ were used to estimate EFx for BaP and benzene, respectively based on the Crettaz et al., (2002) methodology. Additional assumptions are provided in Table 3. According to Huijbregts et al. (2005),

$$
E F_{x}(\text { cancer })=\frac{1}{E D 50_{x, r}} \times p(d \mid \Delta T U) \times D A L Y p
$$

Here $E D 50_{x, r}$ is the lifetime dose $(\mathrm{kg})$ of substance $x$ from exposure route $r$ affecting $50 \%$ of the exposed human population. $E D 50_{x, r}$ is estimated using the $T D 50_{x, a}$ from animal experiments, the daily dose rate $[\mathrm{mg} / \mathrm{kg}(\mathrm{BW})-\mathrm{d}]$ that induces tumors in half of the test animals that would have otherwise been tumor free at no dose. TD50 ${ }_{\mathrm{x}, \mathrm{a}}$ values are available form the Cancer Potency Database (Gold et al. 2005). The animal dose to human dose conversion factors are provided in Table 3. $p(d \mid \Delta T U)$ is the probability of occurrence of a disease, $d$, caused by a marginal change in the ambient toxic unit (TU) [-]. For carcinogens Huijbregts et al. (2005) use a default $p(d \mid \Delta T U$ ) value of 0.03. Huijbregts et al. (2005) use the same definition of DALYP as Crettaz et al. (2002), but because Huijbregts et al. (2005) do not use disability age weighting and discounting, their default $D A L Y \mathrm{p}$ for a carcinogen is $11.5 \mathrm{y}$ lost as opposed to the 6.7 years used by Crettaz et al. (2002). Huijbregts et al. (2005) also report chemical-disease-specific DALYp values, as given in Table B-1b. 
Table 3. Assumptions and conversion factors used to calculate the cancer $\mathrm{FF}_{\mathrm{x}}$

\begin{tabular}{|l|c|c|}
\hline & $\begin{array}{c}\text { Crettaz et al. } \\
(2002)\end{array}$ & $\begin{array}{c}\text { Huijbregts et } \\
\text { al. (2005) }\end{array}$ \\
\hline BW(human) $[\mathrm{kg}]$ & 70 & 70 \\
\hline BW (rat) $[\mathrm{kg}]$ & & 0.25 \\
\hline BW (mouse) $[\mathrm{kg}]$ & & 0.03 \\
\hline BR (human) $\left[\mathrm{m}^{3} / \mathrm{d}\right]$ & 20 & 20 \\
\hline Lifetime (human) [y] & 70 & 75 \\
\hline CF_oral (rat $\rightarrow$ human) & & 4.1 \\
\hline CF_oral (mouse $\rightarrow$ human) & & 7.0 \\
\hline
\end{tabular}

For chemicals which do not have an available TD50 ${ }_{\mathrm{x}, \mathrm{a}}$ value, Huijbregts et al. (2005) estimate ED50 $x$ from the $q_{x}^{*}$, the US EPA cancer potency factor:

$$
E D 50_{x}=0.8 \times \frac{1}{q_{x}^{*}}
$$

As seen from Eq. 3, Crettaz et al. (2002) rely on the $\beta_{E D 10, x}$ that can easily be derived from the ED10 ${ }_{x, h}$. But because ED10 $x, h$ values are not reported for the six chemicals in this study, $\beta_{E D 10, x}$ for these substances is estimated directly from the US EPA $\mathrm{q}_{1}{ }^{*}$, the $95^{\text {th }} \%$ upper confidence bound on the linearized multistage model slope factor $\mathrm{q}_{1}$, using a regression used by Crettaz et al. (2002):

$$
\beta_{E D 10}=0.5 \times q_{1}^{*} \quad\left(\mathrm{r}^{2}=0.95 ; \mathrm{n}=44\right)
$$

In cases where $\mathrm{q}_{1}{ }^{*}$ is not available, Crettaz et al. (2002) have provided the following two equations for estimating ED10 ${ }_{\mathrm{x}, \mathrm{l}}$ from the TD50 $0_{\mathrm{a}(\mathrm{anima}), \mathrm{x}^{\prime}}$

$$
\begin{aligned}
& E D 10_{x, h}=\frac{T D 50_{a, x}}{40} \quad(\text { theoretical; one-hit model of extra risk) } \\
& E D 10_{x, h}=\frac{T D 50_{a, x}}{25} \quad\left(\text { empirical; } \mathrm{r}^{2}=0.75 ; \mathrm{n}=37\right)
\end{aligned}
$$

\subsubsection{The effect factor $\left(E F_{x}\right)$ for non-cancer effects}

The effect factors, $\mathrm{EF}_{\mathrm{x}}$, for non-cancer endpoints were obtained using the approach of Pennington et al. (2002) based on the ED10 ${ }_{x, h}$ for non-cancer endpoints and including threshold effects, 


$$
\beta_{E D 10, x}=0.1 /\left(E D 10_{x, \mathrm{~h}}-T h r\right)
$$

Thr is the biological threshold level (mg/ $\mathrm{kg}-\mathrm{BW} /$ day) and other factors are as defined above.

Because $\mathrm{BaP}$ and naphthalene are primarily carcinogens and their overall EF and DALYs are dominated by the cancer $\mathrm{EF}$, this report only accounts for non-cancer disease burdens of benzene, $\mathrm{NOx}$ and $\mathrm{SO}_{2}$. For benzene, the $\mathrm{ED} 1 \mathrm{O}_{\mathrm{h}}$ is derived from the benchmark dose computation (BMD, not BMDL) from the exposure-response data on decreased absolute lymphocyte count (ALC) reported by Rothman et al. (1996). Based on the US EPA benchmark dose software (v1.3.2), a BMD of $3.34 \mathrm{ppm}$ (converted to an ED10 of $3.0 \mathrm{mg} / \mathrm{kg}-\mathrm{BW} / \mathrm{d}$ ) is derived and used as an estimator of $\mathrm{ED}_{10}$.

For $\mathrm{NO}_{\mathrm{x}}$ and $\mathrm{SO}_{2}$ the $\mathrm{ED}_{10} \mathrm{~h}_{\mathrm{h}}$ is estimated from the following equation reported in Pennington et al. (2002):

$$
\mathrm{ED} 10_{\mathrm{h}}=0.99(\mathrm{RfD})+1.8 \quad\left(\mathrm{r}^{2}=0.88 ; \mathrm{n}=12\right)
$$

The RfD is the US EPA reference dose, which is interpreted as a safe dose. For this study, RfD values for $\mathrm{NOx}$ and $\mathrm{SO}_{2}$ are derived from the inhalation non-cancer risk values reported in the Scorecard database (Environmental Defense, 2006a and 2006b, respectively). The non-cancer inhalation risk value for $\mathrm{NO}_{2}$ is assumed to apply to NOx.

Because RfD values do not permit inter-chemical comparisons, the ED10 approach proposed by Pennington et al. (2002) was used. The ED10 approach follows the approach to assess carcinogen health effects and is based on bioassay data. The factor of 10 difference between the three non-cancer disease categories proposed by Pennington et al. (2002) comes from the subjective scaling proposed by the International Life Science Institutes panel (Burke et al., 1996). Because cancer effects are also included in the Category 1 effects, the factor of 10 scaling was applied to 6.7 years per disease incidence to derive the Category 2 and 3 non-cancer DALYs. Therefore the default DALYp for a non-cancer substance falls into one of the following three categories:

- Category 1 (irreversible life-shortening effects, e.g., mutations, teratogenic effects, and reproductive effects)

- Category 2 (probably irreversible/life-shortening effects, including immunotoxicity, neurotoxicity, kidney damage, liver damage, heart disease, pulmonary disease)

- Category 3 (reversible/non-life shortening effects, 0.067 y lost/incidence including irritation and sensitization)

Because most of the known non-cancer health effects from exposures to benzene, $\mathrm{NOx}$, and $\mathrm{SO}_{2}$ likely fall into categories 2 or 3, this study used the $\mathrm{EF}_{x}$, and the resulting HDFs, from these disease categories. 


\subsection{The Magnitude and Uncertainty of Any Added or Averted Disease Burden}

This section describes the methods to estimate the energy, emissions, and disease burden reductions resulting from a case study that postulates increased use of residential fiberglass attic insulation in California. These values are compared with the disease burden levels resulting from the manufacturing of the fiberglass insulation.

\subsubsection{Energy and emissions reductions resulting from residential fiberglass attic insulation}

According to the US DOE, up to $30 \%$ of a home's energy loss is due to improper or inadequate insulation (US DOE, 2006). Fiberglass insulation is commonly installed in attics and cathedral ceilings to combat this large heat loss and is therefore the energy efficiency technology considered here. Fiberglass insulation is mostly in rolls and batts, although loose-fill, which is blown into spaces, can also be made of fiberglass. This case study does not consider installation of rigid foam insulation, which is generally used in buildings requiring higher- $\mathrm{R}$ values or those buildings that have space limitations.

To estimate the emissions reductions and subsequent reductions in disease burden from installing additional fiberglass insulation in single-family homes in California, this study relied primarily on housing characteristics provided by the 2001 database for energy efficiency resources (DEER) Update Study (Energy Commission, 2001). As shown by the DEER study, single-family housing characteristics in California vary dramatically by age of house. Therefore, based on the DEER study data, the median values of housing characteristic from the following three vintages were used:

Pre-1978

1978-1992

1992-present

To account for the decreased emissions from power plants from increased fiberglass insulation in single-family residences, this study estimated the difference in energy consumption $(\triangle \mathrm{Energy}$ $[B t u / y r])$ between current insulation levels and increased levels recommended by the DOE in homes heated with electricity. The method used for calculating $\Delta$ Energy is given by the following equation:

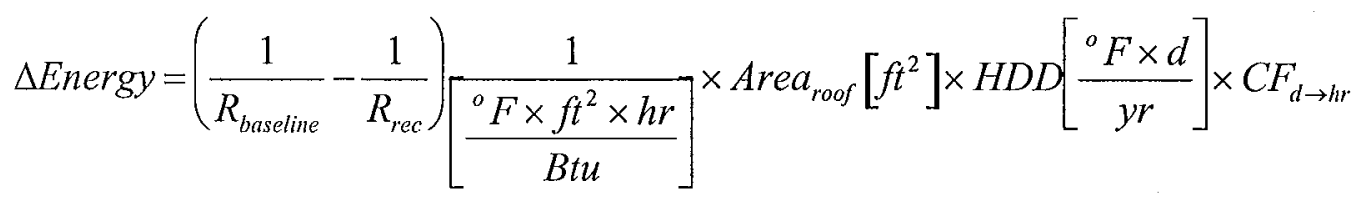

$R_{\text {basline }}$ is the baseline R-values for homes heated with electricity reported in the 2001 DEER study and summarized in Table 4 and $R_{\text {rec }}$ is the additional attic insulation needed to reach the latest DOE recommended insulation requirements. $\mathrm{R}_{\text {rec }}$ applies to "Zone 3 " insulation zones (covering most of California) (DOE 2002) and are 49 [ $\left.\mathrm{ft}^{2}-\mathrm{hr}{ }^{\circ} \mathrm{F} / \mathrm{Btu}\right]$ for attic insulation in homes heated with electricity and $38\left[\mathrm{ft}^{2}-\mathrm{hr}{ }^{\circ} \mathrm{F} / \mathrm{Btu}\right]$ for cathedral ceilings in homes heated with electricity. Area $a_{\text {roof }}\left[\mathrm{ft}^{2}\right]$ is the median roof area summarized in Table 5. In addition, this case 
Table 4. Distribution of attic (and cathedral ceiling for those housing units built after 1992) insulation R-values [ $\left.\mathrm{ft}^{2}-\mathrm{hr}{ }^{\circ} \mathrm{F} / \mathrm{Btu}\right]$ for electricity heated homes from the $2001 \mathrm{DEER}$ study (Energy Commission, 2001)

\begin{tabular}{|c|c|c|c|c|}
\hline Climate Zone & pre-1978 & 1978-1992 & 1992-1998 & post -1998 \\
\hline North Coast & 5.1 & 28 & 30 & 30 \\
\hline South Coast & 5.9 & 21.5 & 30 & 30 \\
\hline South Inland & 5.3 & 23.5 & 30 & 30 \\
\hline Central Valley & 5.3 & 20.1 & 38 & 38 \\
\hline Desert & 5.3 & 21.3 & 38 & 38 \\
\hline & median & & \\
\hline \multicolumn{2}{|r|}{ pre 1978} & 5.3 & & \\
\hline \multicolumn{2}{|r|}{ 1978-1992 } & 21.5 & & \\
\hline \multicolumn{2}{|c|}{ 1992-current } & 30 & & \\
\hline
\end{tabular}

Table 5: Median Area $a_{\text {roof }}\left[\mathrm{ft}^{2}\right]$ of single-family housing units in California from DEER 2001 (Energy Commission, 2001)

\begin{tabular}{|c|c|c|c|c|}
\hline Climate Zone & pre-1978 & 1978-1992 & 1992-1998 & Post-1998 \\
\hline North Coast & 1591 & 1904 & 2164 & 2296 \\
\hline South Coast & 1528 & 2064 & 2270 & 2393 \\
\hline South Inland & 1636 & 1811 & 2118 & 2423 \\
\hline Central Valley & 1528 & 1704 & 2056 & 1949 \\
\hline Desert & 1555 & 1741 & 1643 & 2161 \\
\hline & & Median & & \\
\hline & pre 1978 & 1555 & & \\
\hline & 1978-1992 & 1811 & & \\
\hline & 1992-current & 2163 & & \\
\hline
\end{tabular}

study included the cathedral ceiling area as part of the roof area. Cathedral ceilings are present in homes built after 1992 (Energy Commission, 2001), and their area is assumed to be $25 \%$ of the total footprint area, approximately $1,376 \mathrm{ft}^{2}$ (the median of the total footprint area in the climate zones in California reported in the DEER 2001 study with a range of 1,177 to 1,852 $\mathrm{ft}^{2}$ (Energy 
Commission, 2001). HDD is the heating degree days $\left[{ }^{\circ} \mathrm{F}-\mathrm{d}\right]$ for one year. The assumed value for HDD in this study is 2,700 (the median HDD (base 68) from the DEER 2001 report (Energy Commission, 2001). $\mathrm{CF}_{d \rightarrow \text { lrs }}$ is the conversion factor from day to hours. This study reports an estimate of the decrease in electrical energy demand resulting from the installation of fiberglass insulation with $\mathrm{R}_{\text {rec }}$ for each single-family home selected from a given house-age category. These $\Delta$ Energy [BTU/yr] estimates are given in Table 6.

Table 6. $\Delta$ Energy associated with increased insulation per single-family home [Btu/yr]

\begin{tabular}{|r|c|}
\hline & Electricity heated \\
\hline pre 1978 & $1.7 \times 10^{7}$ \\
\hline $1978-1992$ & $2.7 \times 10^{6}$ \\
\hline 1992 - current & $1.4 \times 10^{\circ}$ \\
\hline
\end{tabular}

"Includes both attic and cathedral ceiling insulation.

The total energy reduction [Btu] for the entire housing stock in California was estimated based on the average of two housing stock distributions studies (US Census of Population and Housing 2000 and EIA 2005) for each house-age category, as shown in Table 7.

Table 7. Distribution of electricity heated homes for the Western region of the US

\begin{tabular}{|r|c|}
\hline pre 1978 & $34 \%$ \\
\hline $1978-1992$ & $43 \%$ \\
\hline 1992-current & $12 \%$ \\
\hline
\end{tabular}

aThe Western region of the US includes Arizona, Colorado, Idaho, Montana, Nevada, New Mexico, Utah, Wyoming, Alaska, California, Hawaii, Oregon, and Washington (US Census Bureau, 2005).

For the state of California, the distribution of energy production in urban and rural counties, the reduction in energy generation due to insulation, and subsequent decreased emissions were assumed to track population distribution. Therefore, based on the cutoff between urban and rural counties ( 35 persons $/ \mathrm{km}^{2}$ ), $7 \%$ of the total California housing stock was rural (CA DoF, 2005).

The distribution of fossil fuel electricity production was assumed to follow the current distribution of in-state sources of electricity generating capacity, as shown in Figure 2. Because coal generated electricity is mostly from the Mohave and Intermountain power plants, approximately $3 \%$ of pollutant emissions resulted from electricity generated from the "rural" region Mohave power plant that is located very close to the California-Nevada border.

The magnitude of emissions eliminated for each chemical $i, \Delta$ emissions $_{\mathrm{i}}(\mathrm{kg} / \mathrm{y})$ as a result of increasing fiberglass attic insulation were estimated as: 


$$
\text { Demissions }_{i}=\Delta \text { Energy } \times \text { emissions }_{i} \times t_{\text {insulation }} \times C F_{\text {Btt } \rightarrow \text { MWe }}
$$

where, $\triangle$ Energy [Btu/y] is given by Eq 10 above; emissions $s_{1}$ are the total California emissions for each chemical $i$, per MWe, $[\mathrm{kg} /(\mathrm{MWe}-\mathrm{y})]$ and obtained using the approach in Section $2.2 ; \mathrm{t}_{\text {insulation }}$

[y] is the lifetime of the fiberglass insulation, assumed to be 50 years; and $\mathrm{CF}_{\mathrm{Btu} \rightarrow \mathrm{MWe}}$ is the conversion factor from Btu to MWe-y (3.345 x 10 $0^{-11}$ MWe-y per Btu).

The Aemissions were estimated separately for urban and rural electricity energy generating power plants in California. These estimates of emissions averted were then divided by the respective MWe from the fuel source in a given region, e.g., the total MWe generated from natural gas in urban regions.

The final step of the calculation was to report the DALYs saved over the lifetime of the fiberglass insulation, per Mt of insulation installed. This was based on the amount of insulation to reach $\mathrm{R}_{\mathrm{rec}}$ levels, i.e., $1.04 \mathrm{Mt}$ in urban and $7.8 \times 10^{-2} \mathrm{Mt}$ in rural electricity heated homes.

\subsection{Emissions from Fiberglass Manufacturing}

To complete the case study requires a quantification of both emissions from the manufacture of residential fiberglass insulation and emissions from energy required to manufacture this insulation. A preliminary analysis indicates that the emissions from energy needed to manufacture insulation are quite small compared to emissions from either the insulation manufacturing process or emissions from the energy saved. The electrical energy used to manufacture 1.1 Mt of insulation is approximately $3.1 \times 10^{10} \mathrm{MJ}$ (based on an estimate of 27.9 $\mathrm{MJ} / \mathrm{kg}$ for the embodied energy of fiberglass materials reported by Franklin Associates (1991). This amount is three orders of magnitude less than the $6.0 \times 10^{13} \mathrm{MJ}$ of electrical energy saved over the 50-y assumed lifetime of the insulation. Therefore the focus here is only on manufacturing emissions, and not on an explicit analysis of emissions added by electrical energy to produce insulation.

The emissions associated with manufacturing fiberglass insulation arise from the various steps outlined in Figure 5. Manufacturing emissions are estimated according to:

$$
\text { Emissions }_{\text {fiberglass }, i}=E F_{\text {fiberglass }, i} \times \rho_{\text {fiberglass }} \times V_{\text {insulation }}
$$

where, $\mathrm{EF}_{\text {fiberglass } i}$ is the emission factor of pollutant, $\mathrm{i}[\mathrm{kg}$ pollutant $/ \mathrm{Mg}$ insulation, finished product] as reported in the USEPA AP-42 (EPA 1985); $\rho_{\text {fiberglass }}$ is the density of fiberglass (9 $\mathrm{kg} / \mathrm{m} 3 ; \mathrm{EPA}, 1985) ; \mathrm{V}_{\text {insulation }}$ is the volume of installed insulation needed to meet the DOE recommended R-values for insulation in California (i.e., a "Zone 3" region) (DOE 2002). The baseline $\mathrm{R}$-values are given in Table 4 . Table 5 displays the total surface area requiring insulation. This area was multiplied by an average R-value per inch of 3.25 corresponding with fiberglass batts and blankets.

The HDFs (DALYs per kg insulation manufactured) associated with the chemical emissions of the fiberglass insulation were also calculated using the same chemicals and methods described above for power plant emissions. The DALYs caused by the insulation manufacture were compared with the DALYs saved over the lifetime of the fiberglass insulation-estimated as 50 years. 


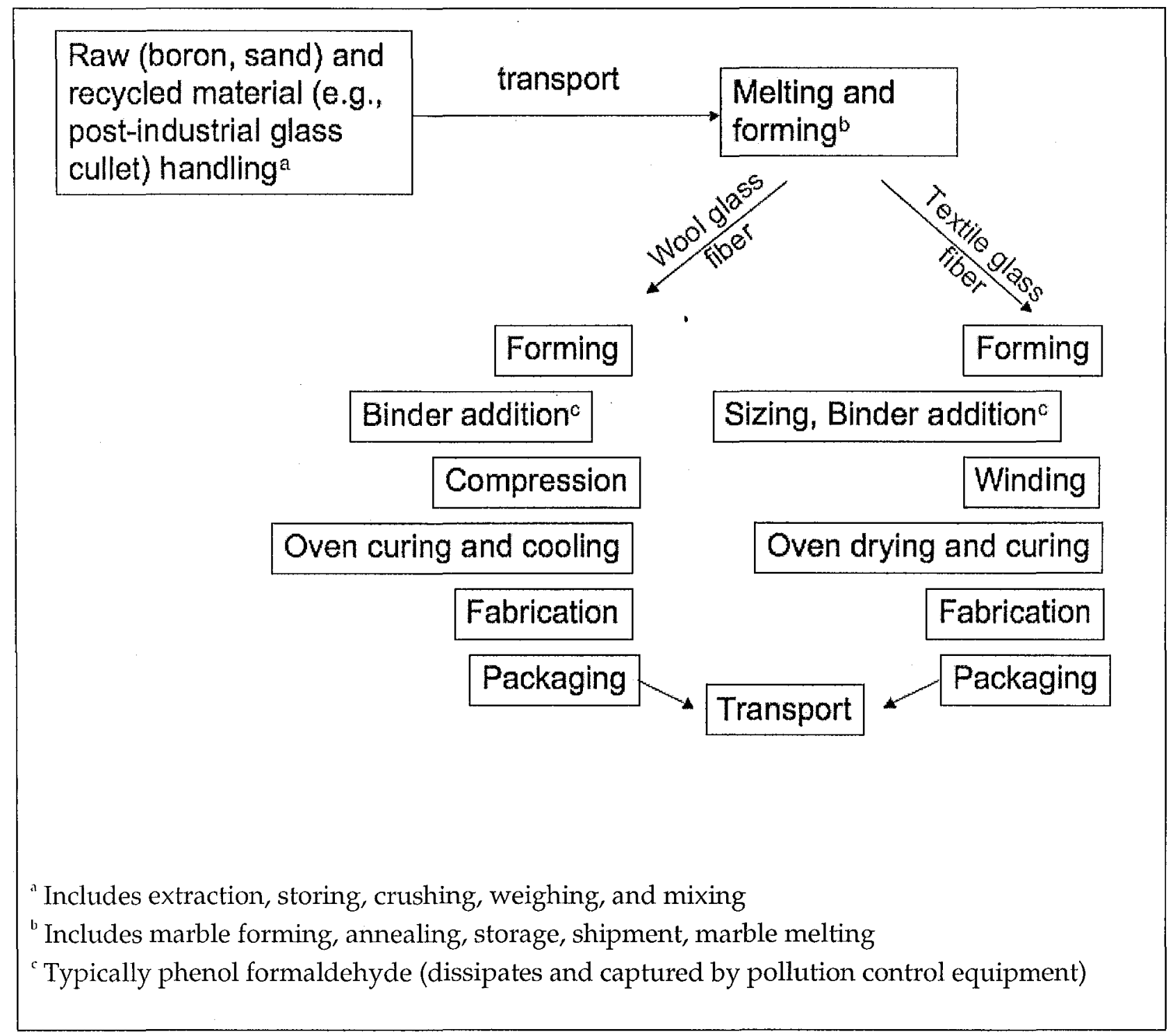

Figure 5. Materials and processes involved in the manufacture of fiberglass insulation (adapted from: EPA, 1985) 


\subsection{Project Results}

The results of this project are presented in four steps. First, the magnitude and location of emissions for the pollutants of concern are presented as cumulative emissions to California urban and rural regions in kg/(MWe-y). Next, the two elements of the HDF are considered. Human exposure potential is presented as the individual intake fraction, that is the fraction of $\mathrm{kg} /($ MWe-y) that is taken into the population. The effect factor is expressed as DALYs attributable to combined urban and rural emissions. Then this information is used to determine the reduction of emissions and disease burden attributable to increasing attic insulation in California. Finally, the disease burden attributable to the manufacture of the fiberglass insulation used is estimated and compared to the disease burden averted.

\subsection{Magnitude and Location of Emissions}

A total of $3.1 \times 10^{4} \mathrm{MWe}$ and $7.1 \times 10^{3}$ MWe are online, respectively, in urban and rural regions of California. The power plants supplying this electrical energy are listed in Attachment I to this report.

Table 8 lists for each candidate pollutant the estimated range of emissions for urban and rural regions in kg per MWe-y from California electricity generating plants. Ranges are provided to account for uncertainty in emissions due to variations in reported plant efficiencies (provided in Appendix A Table A-1). These ranges are within the same order of magnitude in each region for each pollutant from plants powered by a given fuel type. Because the San Francisco and South Coast Air Basins are characterized as urban regions, they have emissions estimates per MWe-y that are most similar to those estimated for urban regions. This is summarized in Table 8 (c and d).

The fact that the efficiencies of coal plants vary over a very small range (as can be seen in Table A-1) is reflected in the narrow range of the emissions per MWe-y in the urban regions (Table $8 \mathrm{a}, \mathrm{c}$ and d). Because all of the coal-fired plants located in rural regions use cogeneration technologies and this study located only one efficiency for this fuel-technology combination $(0.4$, Table A-1), there is a single emissions value in place of a range for these plants in Table $8 \mathrm{~b}$.

The total emissions from electricity-producing power plants in California estimated in this report are most likely higher, not lower, than actual emissions. This conclusion is drawn from the fact that $\mathrm{NOx}$ and $\mathrm{SO}_{2}$ emissions, which are available from the EPA's Emissions and Generating Resource Integrated Database (eGRID) (EPA, 2003) are 4.2 and 1.3 Mt per MWe-y respectively, for California for the year 2000. eGRID relies on AP-42 emission factors for power plants that do not report emissions. In comparison to the eGRID emissions, the median California-wide emissions of $\mathrm{NOx}$ and $\mathrm{SO}_{2}$ estimated from the primary fuel/technology power plants in this report are $8.4 \mathrm{Mt}$ of NOx and $2.5 \mathrm{Mt} \mathrm{SO}_{2}$, per MWe-y, for 2004. eGRID does not report emissions of other pollutants of interest in this study. However, for both $\mathrm{NOx}$ and $\mathrm{SO}_{2}$, the emissions estimated in this report are within a factor of two from eGRID, which is reasonable given the uncertainties inherent in these calculations. In addition, although this report relies on the assumption that installed capacity is equivalent to generation, the resulting total estimated MWe-y generated in California from each fuel-technology compares well with that reported in eGRID, i.e., within a factor of 2 for coal and WTE/other fossil, and within a factor of 3 for natural gas fueled technologies (EPA, 2003). The one exception is for oil fueled 
power plant generation. The MWe generated from primarily oil fueled power plants estimated by the Energy Commission (2004) database is an order of magnitude greater than that reported in eGRID, i.e., 5000 MWe-y compared to $300 \mathrm{MWe}-\mathrm{y}$ (EPA, 2003). This is most likely due to fuel classification uncertainties. For example at least four electrical energy producing power plants (ranging between 560-2087 MWe-y capacity in the Energy Commission database, 2004 are labeled as $100 \%$ natural gas fired plants in eGRID, whereas the Energy Commission database (2004) reports distillate oil as their 'primary fuel.' These four plants--Alamitos, Etiwanda, Huntington Beach, and Mandalay - are included in Attachment I to this report. Because distillate oil combustion emits much more $\mathrm{SO}_{2}$ and $\mathrm{NOx}$ than natural gas combustion, the result is higher estimates of $\mathrm{SO}_{2}$ and $\mathrm{NOx}$ emissions per functional unit, $\mathrm{MWe}-\mathrm{y}$, than if these four plants were assumed to burn natural gas.

The authors of this report did not focus on specific power plants. But in order to assess the reliability of the emissions used in the study, the authors used the plant-specific emissions reported for the $1640 \mathrm{MWe}-\mathrm{y}$ large-scale Mohave coal-fired power plant for comparison. Environmental Defense (2005) reports $\mathrm{SO}_{2}$ and NOx estimates of emissions from this plant of 39,100 and 19,200 tons per year, respectively. Additionally, the Clean Air Markets database available from the EPA's eGRID website also reports similar emissions for the Mohave coal plant in 2004, 43,600 tons of $\mathrm{SO}_{2}$ and 20,900 tons of NOx (EPA, 2003). Based on the methods and data sources applied in this report, this facility released 41,000 tons of $\mathrm{SO}_{2}$ and 30,000 tons of NOx in 2004. Although the emissions factors and methods vary in each of these approaches, they all provide very similar results and increase confidence about the reliability of the emissions estimates of this report. The slightly higher NOx emissions reported here are most likely due to the higher emissions factor data from the AP-42, $0.54 \mathrm{lbs} / \mathrm{MMBtu}$ (input) in comparison with $0.41 \mathrm{lbs}$ NOx/MMBtu (input) specific to the Mohave coal plant, available from the eGRID database. Therefore, it is important to note that the ranges listed in Table 8 may not fully reflect the range of uncertainty in emissions factors. 
Table 8. Emissions estimates [kg/MWe-y] from coal, natural gas, oil, and WTE primary fuel powered electricity generating plants in a) urban and b) rural regions of California

a) Urban regions

\begin{tabular}{|l|c|c|c|c|}
\hline & Coal & $\begin{array}{c}\text { Natural } \\
\text { Gas }\end{array}$ & Oil $^{\mathrm{a}}$ & WTE $^{\mathrm{b}}$ \\
\hline Benzo(a)pyrene & $\begin{array}{c}2.97 \times 10^{-4}- \\
3.03 \times 10^{-4}\end{array}$ & $\begin{array}{c}1.6 \times 10^{-2}- \\
2.7 \times 10^{-2}\end{array}$ & $1.3-3.6$ & $\mathrm{n} / \mathrm{a}$ \\
\hline Benzene & $1.5-1.7$ & $\begin{array}{c}1.5 \times 10^{-1}- \\
2.6 \times 10^{-1}\end{array}$ & $\begin{array}{c}9.8 \times 10^{-1}- \\
2.7\end{array}$ & $\begin{array}{c}5.2 \times 10^{-1}- \\
1.3\end{array}$ \\
\hline Naphthalene & $\begin{array}{c}1.5 \times 10^{-2}- \\
1.7 \times 10^{-2}\end{array}$ & $\begin{array}{c}2.1 \times 10^{-2}- \\
3.9 \times 10^{-2}\end{array}$ & $\begin{array}{c}7.1 \times 10^{-1}- \\
1.9\end{array}$ & $\mathrm{n} / \mathrm{a}$ \\
\hline NOx & $1.6 \times 10^{4}-$ & $4.0 \times 10^{3}-$ & $1.2 \times 10^{4}-3$ \\
& $1.7 \times 10^{4}$ & $7.7 \times 10^{3}$ & $4.2 \times 10^{4}$ & $1.1 \times 10^{4}$ \\
\hline PM2.5 $^{4}$ & $3.4 \times 10^{3}-$ & $35.1-58.9$ & $1.8 \times 10^{2}-$ & $\mathrm{n} / \mathrm{a}$ \\
& $3.8 \times 10^{3}$ & & $4.5 \times 10^{2}$ & \\
\hline $\mathrm{SO}_{2}$ & $2.2 \times 10^{4}-$ & $39.1-69.4$ & $6.6 \times 10^{3}-$ & $1.1 \times 10^{3}-$ \\
& $2.5 \times 10^{4}$ & & $1.6 \times 10^{4}$ & $2.9 \times 10^{3}$ \\
\hline
\end{tabular}

b) Rural regions

\begin{tabular}{|l|c|c|c|c|}
\hline & Coal $^{\text {c }}$ & $\begin{array}{c}\text { Natural } \\
\text { Gas }\end{array}$ & Oil $^{\text {a }}$ & WTE $^{\text {b }}$ \\
\hline Benzo(a)pyrene & $5.5 \times 10^{-5}$ & $\begin{array}{c}2.7 \times 10^{-2}- \\
5.0 \times 10^{-2}\end{array}$ & $\begin{array}{c}9.8 \times 10^{-1}- \\
2.8\end{array}$ & $\mathrm{n} / \mathrm{a}$ \\
\hline Benzene & 1.9 & $\begin{array}{c}1.7 \times 10^{-1}- \\
1.4-\end{array}$ & $3.4 \times 10^{-1}-$ \\
& & $3.1 \times 10^{-1}$ & 3.8 & $4.9 \times 10^{-1}$ \\
\hline Naphthalene & $1.9 \times 10^{-2}$ & $2.1 \times 10^{-2}-$ & $9.1 \times 10^{-1}-$ & $\mathrm{n} / \mathrm{a}$ \\
& & $4.0 \times 10^{-2}$ & 2.5 & \\
\hline NOx & $2.0 \times 10^{4}$ & $3.8 \times 10^{3}-$ & $1.5 \times 10^{4}-$ & $2.3 \times 10^{3}-$ \\
& & $7.2 \times 10^{3}$ & $4.0 \times 10^{4}$ & $3.3 \times 10^{3}$ \\
\hline PM2.5 $^{2}$ & $4.2 \times 10^{3}$ & $8.2 \times 10^{1}-$ & $2.3 \times 10^{2}-$ & $\mathrm{n} / \mathrm{a}$ \\
& & $1.5 \times 10^{2}$ & $5.8 \times 10^{2}$ & \\
\hline SO $_{2}$ & $2.0 \times 10^{4}$ & $4.7 \times 10^{1}-$ & $7.7 \times 10^{3}-$ & $7.3 \times 10^{2}-$ \\
& & $8.7 \times 10^{1}$ & $1.9 \times 10^{4}$ & $1.1 \times 10^{3}$ \\
\hline
\end{tabular}


c) San Francisco Bay Area air basin

\begin{tabular}{|l|c|c|c|c|}
\hline & Coal $^{\mathrm{d}}$ & $\begin{array}{c}\text { Natural } \\
\text { Gas }\end{array}$ & Oil $^{\mathrm{a}}$ & WTE $^{\mathrm{b}}$ \\
\hline Benzo(a)pyrene & $\begin{array}{c}4.2 \times 10^{-5}- \\
5.0 \times 10^{-5}\end{array}$ & $\begin{array}{c}2.0 \times 10^{-2}- \\
3.1 \times 10^{-2}\end{array}$ & $1.3-3.6$ & $\mathrm{n} / \mathrm{a}$ \\
\hline Benzene & $1.5-1.7$ & $\begin{array}{c}1.4 \times 10^{-1}- \\
2.2 \times 10^{-1}\end{array}$ & $1.3-3.6$ & $5.6 \times 10^{-1}-$ \\
& & & 1.2 \\
\hline Naphthalene & $1.5 \times 10^{-2}-$ & $2.0 \times 10^{-2}-$ & $9.0 \times 10^{-1}-$ & $\mathrm{n} / \mathrm{a}$ \\
& $1.7 \times 10^{-2}$ & $3.3 \times 10^{-2}$ & 2.5 & \\
\hline NOx & $1.2 \times 10^{-4}-$ & $3.9 \times 10^{3}-$ & $1.4 \times 10^{4}-$ & $3.9 \times 10^{3}-$ \\
& $1.4 \times 10^{-4}$ & $7.0 \times 10^{3}$ & $4.1 \times 10^{4}$ & $8.3 \times 10^{3}$ \\
\hline $\mathrm{PM} 2.5^{3.2 \times 10^{3}-}$ & $42.6-$ & $2.1 \times 10^{2}-$ & $\mathrm{n} / \mathrm{a}$ \\
& $3.8 \times 10^{3}$ & 65.4 & $6.0 \times 10^{2}$ & \\
\hline $\mathrm{SO}_{2}$ & $2.1 \times 10^{4}-$ & $38.6-$ & $6.9 \times 10^{3}-$ & $1.2 \times 10^{3}-$ \\
& $2.5 \times 10^{4}$ & 62.4 & $2.1 \times 10^{4}$ & $2.6 \times 10^{3}$ \\
\hline
\end{tabular}

d) South Coast air basin

\begin{tabular}{|c|c|c|c|c|}
\hline & Coal & $\begin{array}{c}\text { Natural } \\
\text { Gas }\end{array}$ & $\mathrm{Oil}^{\mathrm{a}}$ & $\mathrm{WTE}^{\mathrm{b}}$ \\
\hline Benzo(a)pyrene & $\begin{array}{c}5.1 \times 10^{-5}- \\
5.5 \times 10^{-5}\end{array}$ & $\begin{array}{c}1.4 \times 10^{-2}- \\
2.3 \times 10^{-2}\end{array}$ & $1.3-3.6$ & $\mathrm{n} / \mathrm{a}$ \\
\hline Benzene & $1.7-1.9$ & $\begin{array}{c}1.1 \times 10^{-1}- \\
2.0 \times 10^{-1}\end{array}$ & $0.9-2.6$ & $0.4-1.2$ \\
\hline Naphthalene & $\begin{array}{c}1.7 \times 10^{-2}- \\
1.9 \times 10^{-2}\end{array}$ & $\begin{array}{l}1.9 \times 10^{-2}- \\
3.7 \times 10^{-2}\end{array}$ & $0.7-1.8$ & $\mathrm{n} / \mathrm{a}$ \\
\hline $\mathrm{NOx}$ & $\begin{array}{c}1.9 \times 10^{4}- \\
2.1 \times 10^{4}\end{array}$ & $\begin{array}{l}4.0 \times 10^{3}- \\
8.2 \times 10^{3}\end{array}$ & $\begin{array}{c}1.1 \times 10^{4}- \\
2.9 \times 10^{4}\end{array}$ & $\begin{array}{c}4.2 \times 10^{3}- \\
1.1 \times 10^{4}\end{array}$ \\
\hline PM2.5 & $\begin{array}{c}3.8 \times 10^{3}- \\
4.2 \times 10^{3}\end{array}$ & $31.1-51.6$ & $\begin{array}{c}1.8 \times 10^{2}- \\
4.3 \times 10^{2}\end{array}$ & $\mathrm{n} / \mathrm{a}$ \\
\hline $\mathrm{SO}_{2}$ & $\begin{array}{c}2.5 \times 10^{4}- \\
2.8 \times 10^{4}\end{array}$ & $43.3-78.8$ & $\begin{array}{c}6.5 \times 10^{3}- \\
1.5 \times 10^{4}\end{array}$ & $\begin{array}{c}9.9 \times 10^{2}- \\
2.7 \times 10^{3}\end{array}$ \\
\hline
\end{tabular}

n/a: "not available", referring to emissions factors from primary fuel technology

${ }^{a}$ Distillate and diesel

${ }^{\mathrm{b}}$ Digester, landfill, and natural gas only

c Same whether or not Mohave plant is included

d Petroleum and crude oil as primary fuel 


\subsection{Levels of Human Exposure}

The levels of human exposure are characterized in terms of the individual intake fraction, iFi. The iFis have value ranges that reflect both the variability of emissions estimates $[\mathrm{kg} / \mathrm{y}]$ in each region and the variability in human exposure factors used in CalTOX. The relationship between the variance of $i F i$ estimates and input variances, which reflect uncertainty and variability, can be determined using one of a number of variance propagation methods (Morgan and Henrion, 1990). In this study, Monte Carlo sampling provided the method for propagating parameter variance into outcome (iFi) variance. In a standard Monte Carlo analysis, simple random sampling is used to select each member of the set parameter value realizations. Each model input parameter is represented by a probability-density function that defines both the range of values that the input parameters can have and the probability that the parameters are within any subinterval of that range. Each input is represented by a cumulative distribution function in which there is a one-to-one correspondence between a probability and values. A random number generator is used to select probability in the range of 0 to 1 . This probability is then used to select a corresponding parameter value. Monte Carlo sampling was performed with the program Crystal Ball v 5.0. All variable parameters in CalTOX were run probabilistically and the source term to air was input as a Beta distribution with both shape parameters set to 2 and the range defined by the minimum and maximum of emissions derived from the fuel-plant efficiencies reported in Table A-1 of Appendix A. The full distributions of the $i F i$ for each pollutant in each region are provided in Appendix B, Figures B-1 through B-6. The median values of the cumulative (all route) $i F i$ distributions are used for the comparative assessments presented below. The median was selected because it is essentially the same as the geometric mean, which is more appropriate when input parameters have large and logarithmic variations. Because this study was concerned with an archetypal individual living in a given region, the median values are considered a more representative measure of intake.

Table 9 provides a summary of the pollutant and region-specific $i F i$ values used for this study. For all six pollutants considered, with the exception of $\mathrm{BaP}$, only the inhalation pathway is a significant contributor to overall intake. Therefore, the total (ingestion + ingestion) intake and inhalation only median iFis are presented separately for BaP in Table 9. For BaP in each region considered, the contribution to overall $i F i$ due to inhalation intake was $\sim 1.3 \%$ of the total intake (ingestion and inhalation) at the median result. For PM2.5, the $i F i$ is sensitive to the soil/water distribution coefficient, $\left(\mathrm{K}_{\mathrm{d}}[\mathrm{L} / \mathrm{kg}]\right)$ used for the surface soil layer. In Appendix B (Figure B-6), distributions based on $\mathrm{K}_{\mathrm{d}}$ values of $10^{6}$ and $10^{7}$ are presented for completeness. However, the distributions based on the two $\mathrm{K}_{\mathrm{d}}$ values are nearly identical. In Table 9, the median $i F i$ values based on urban (all counties, and also for those counties with at least one power plant) and rural counties (all counties) are most similar. The $i F i$ distributions for rural counties with power

plants have slightly higher values than the urban and rural (all counties) regions because of the smaller spatial extent of these counties. Smaller spatial scale primarily explains why the $i F i$ values are largest in the SFBA air basin. 
Table 9. Median values of the iFi [-] for each pollutant in each region

\begin{tabular}{|l|c|c|c|c|c|}
\hline & Urban $^{a}$ & $\begin{array}{c}\text { Rural-all } \\
\text { counties }\end{array}$ & $\begin{array}{c}\text { Rural- } \\
\text { counties } \\
\text { with Power } \\
\text { Plants }\end{array}$ & $\begin{array}{c}\text { South Coast } \\
\text { Air Basin }\end{array}$ & $\begin{array}{c}\text { San } \\
\text { Francisco Air } \\
\text { Basin }\end{array}$ \\
\hline $\begin{array}{l}\text { BaP (total = ingestion } \\
\text { + inhalation) }\end{array}$ & $4.2 \times 10^{-13}$ & $3.6 \times 10^{-13}$ & $6.7 \times 10^{-13}$ & $9.5 \times 10^{-13}$ & $3.7 \times 10^{-12}$ \\
\hline BaP (inhalation only) & $5.4 \times 10^{-15}$ & $4.7 \times 10^{-15}$ & $8.9 \times 10^{-15}$ & $1.2 \times 10^{-14}$ & $4.9 \times 10^{-14}$ \\
\hline Benzene & $2.9 \times 10^{-13}$ & $2.6 \times 10^{-13}$ & $4.0 \times 10^{-13}$ & $5.2 \times 10^{-13}$ & $1.3 \times 10^{-12}$ \\
\hline Naphthalene & $5.8 \times 10^{-14}$ & $5.1 \times 10^{-14}$ & $9.0 \times 10^{-14}$ & $1.3 \times 10^{-13}$ & $4.4 \times 10^{-13}$ \\
\hline PM2.5 & $1.0 \times 10^{-13}$ & $9.2 \times 10^{-14}$ & $1.7 \times 10^{-13}$ & $2.2 \times 10^{-13}$ & $7.1 \times 10^{-13}$ \\
\hline $\mathrm{NOx}^{\mathrm{c}}$ & $1.1 \times 10^{-13}$ & $9.7 \times 10^{-14}$ & $1.6 \times 10^{-13}$ & $2.3 \times 10^{-13}$ & $7.3 \times 10^{-13}$ \\
\hline $\mathrm{SO}_{2}$ & $2.1 \times 10^{-13}$ & $1.9 \times 10^{-13}$ & $3.2 \times 10^{-13}$ & $4.1 \times 10^{-13}$ & $1.2 \times 10^{-12}$ \\
\hline
\end{tabular}

"Same iFi distributions result whether analysis considers only the population and area of urban counties with power plants, or all urban counties

${ }^{b}$ Same median iFi whether $\mathrm{K}_{\mathrm{d}}$ of PM2.5 is $10^{6}$ or $10^{7}[\mathrm{~L} / \mathrm{kg}]$

"Estimated by $\mathrm{NO}_{2}$

\subsection{Results for the Disease Burden Calculations}

\subsubsection{Effect factors (EFx) for cancer and non-cancer diseases}

For health effects associated with cancer, non-cancer, and PM2.5 premature mortality, both the Crettaz et al (2002) and Huijbregts et al. (2005) approaches were considered in order to select an effect factor used to characterize the HDF. The $\mathrm{EF}_{x}$ from each method was calculated and converted to their logarithmic values. Then the log mean (midpoint of the maximum and minimum of the logarithms, divided by 2) was computed. With the exception of PM2.5, the EFx nearest to the computed log mean value was selected and is reported in Table 10. For PM2.5, only one value by each method was estimated and the midpoint is given in Table 10. Appendix B, Table B-1, provides the complete set of EFx derived by the Crettaz et al (2002) and Huijbregts et al. (2005) methods (Tables B-1a and B-1b, respectively). For carcinogens, because of the selection criteria for the appropriate $\mathrm{EFx}$ value, the values selected for $\mathrm{BaP}$ and benzene are based on the $q_{1}^{*}$ and the default DALYp of 6.7 years, whereas for naphthalene, the EFx is based on the Huijbrejts et al. (2005) methodology. 
Table 10. The EFx estimates for each pollutant

\begin{tabular}{|c|c|c|}
\hline & EFx derivation comment & $\begin{array}{c}\text { EFx } \\
\text { [DALYs/mg } \\
\text { intake] }\end{array}$ \\
\hline \multicolumn{3}{|l|}{ Cancer } \\
\hline Benzene & $\begin{array}{l}\text { Lower bound of range on } \mathrm{q}_{1}^{*} \text { (inhal-->oral); Crettaz et al. } \\
\text { (2002) method. }\end{array}$ & $1.4 \times 10^{-8}$ \\
\hline $\mathrm{BaP}$ & $\begin{array}{l}\text { Upper bound of } \mathrm{q}_{1}^{*} \text { (oral) reported in IRIS; Huijbregts et al. } \\
(2005) \text { method. }\end{array}$ & $5.0 \times 10^{-6}$ \\
\hline Naphthalene & $\begin{array}{l}\text { Specific DALYe and } \mathrm{p}(\mathrm{d} \mid \cdot \mathrm{TU}) \text { for stomach cancer }(0.035, \\
\text { 13.6); Huijbregts et al. }(2005) \text { method. }\end{array}$ & $1.1 \times 10^{-8}$ \\
\hline \multicolumn{3}{|l|}{ Non-cancer } \\
\hline \multirow[t]{3}{*}{ Benzene } & $\begin{array}{l}\text { BMD from Rothman et al (1996) for decrease in absolute } \\
\text { lymphocyte count }\end{array}$ & \\
\hline & Category 2: & $1.2 \times 10^{-8}$ \\
\hline & Category 3: & $1.2 \times 10^{-9}$ \\
\hline \multirow[t]{3}{*}{ NOx } & \begin{tabular}{|l|} 
ED10h estimated from the inhalation non-cancer risk \\
values ${ }^{a}$ of $\mathrm{NO}_{2}\left(5.7 \times 10^{-3} \mathrm{mg} / \mathrm{kg} \mathrm{BW} / \mathrm{d}\right.$, Environmental \\
Defense, 2006a)
\end{tabular} & \\
\hline & Category 2: & $9.9 \times 10^{-8}$ \\
\hline & Category 3: & $9.9 \times 10^{-9}$ \\
\hline \multirow[t]{3}{*}{$\mathrm{SO}_{2}$} & $\begin{array}{l}\text { ED10 estimated from the inhalation non-cancer risk value } \\
\left(1.9 \times 10^{-1} \mathrm{mg} / \mathrm{kg} \text { BW } / \mathrm{d} \text {, Environmental Defense, } 2006 \mathrm{~b}\right)\end{array}$ & \\
\hline & Category 2: & $3.1 \times 10^{-9}$ \\
\hline & Category 3: & $3.1 \times 10^{-10}$ \\
\hline \multicolumn{3}{|c|}{ Premature mortality } \\
\hline PM2.5 & $\begin{array}{l}\text { based on } 1 \mu \mathrm{g} / \mathrm{m}^{3} \text { increase in annual PM2.5 mean } \\
\text { concentrations leading to a } 0.4 \% \text { increase in premature } \\
\text { deaths (Pope et al., 2002)). The midpoint from methods of } \\
\text { Crettaz et al. (2002) and Huijbregts et al. (2005). }\end{array}$ & $1.4 \times 10^{-5}$ \\
\hline
\end{tabular}

assuming $70 \mathrm{~kg}$ body weight and breathing rate of $20 \mathrm{~m}^{3} / \mathrm{d}$

${ }^{\mathrm{b}}$ The PM2.5 EF reflects premature mortality, including cancer and other diseases.

Table 10 provides some insights of interest for making the HDF calculation. First, it reveals that when the EFx for non-cancer effects for benzene are based on Category 2 diseases, one obtains nearly the same value as for the cancer EFx. To obtain EFx for nitrogen dioxide and sulfur dioxide, the Huijbregts et al (2005) method requires either a no-observed effect level (NOEL) or the lowest-observed effect level (LOEL). But these are not reported for nitrogen dioxide and sulfur dioxide. So, a comparison of non-cancer HDFs with the Pennington et al (2002) analysis for these two chemicals was not possible. 


\subsubsection{Human damage factors (HDFs) for cancer and non-cancer diseases}

The combined effect factors (EFx) for both cancer and non-cancer burden and the fate factor (FFx) are combined to obtain human damage factors expressed as DALYs/kg(emitted) for each pollutant. These results are summarized in Table 11. These HDF values result from combining the cancer and non-cancer (Category 2) EFx values given in Table 10 with the FFx, according to Eq. 2. For the FFx, the $i F i$ values reported in Table 9 were converted to a population based $i F$, based on the populations given in Table 2 .

Table 11. Chemical specific HDFs (DALYs/kg emitted) for cancer, non-cancer and premature mortality health effects in the population of regions of California

\begin{tabular}{|l|c|c|c|c|c|}
\hline & $\begin{array}{c}\text { Urban } \\
\text { counties }\end{array}$ & $\begin{array}{c}\text { Rural-all } \\
\text { counties }\end{array}$ & $\begin{array}{c}\text { Rural- } \\
\text { counties } \\
\text { with power } \\
\text { plants }\end{array}$ & $\begin{array}{c}\text { South Coast } \\
\text { Air Basin }\end{array}$ & $\begin{array}{c}\text { San } \\
\text { Francisco } \\
\text { Bay Area Air } \\
\text { Basin }\end{array}$ \\
\hline Cancer & $1.3 \times 10^{-7}$ & $9.8 \times 10^{-9}$ & $1.3 \times 10^{-8}$ & $1.3 \times 10^{-7}$ & $1.3 \times 10^{-7}$ \\
\hline Benzene & $7.1 \times 10^{-5}$ & $4.7 \times 10^{-6}$ & $7.5 \times 10^{-6}$ & $8.1 \times 10^{-5}$ & $1.3 \times 10^{-4}$ \\
\hline $\begin{array}{l}\text { BaP (ingestion and } \\
\text { inhalation) }\end{array}$ & $9.1 \times 10^{-7}$ & $6.2 \times 10^{-8}$ & $1.0 \times 10^{-7}$ & $1.0 \times 10^{-6}$ & $1.7 \times 10^{-6}$ \\
\hline $\begin{array}{l}\text { BaP } \\
\text { (inhalation only) }\end{array}$ & $2.0 \times 10^{-8}$ & $1.4 \times 10^{-9}$ & $2.1 \times 10^{-9}$ & $2.2 \times 10^{-8}$ & $2.9 \times 10^{-8}$ \\
\hline Naphthalene & $1.1 \times 10^{-7}$ & $8.4 \times 10^{-9}$ & $1.1 \times 10^{-8}$ & $1.1 \times 10^{-7}$ & $1.1 \times 10^{-7}$ \\
\hline Non-Cancer & $3.6 \times 10^{-7}$ & $2.5 \times 10^{-8}$ & $3.5 \times 10^{-8}$ & $3.7 \times 10^{-7}$ & $5.0 \times 10^{-7}$ \\
\hline Benzene & $2.2 \times 10^{-8}$ & $1.5 \times 10^{-9}$ & $2.2 \times 10^{-9}$ & $2.1 \times 10^{-8}$ & $2.6 \times 10^{-8}$ \\
\hline NOx & $4.6 \times 10^{-5}$ & $3.3 \times 10^{-6}$ & $4.9 \times 10^{-6}$ & $5.1 \times 10^{-5}$ & $6.8 \times 10^{-5}$ \\
\hline SO
\end{tabular}

"Result is consistent whether or not the area and population of the region includes only counties with power plants, or all urban counties

Table 11 reveals a number of issues of interest. First, the HDF values are somewhat smaller than the researchers expected. But comparisons below with the work of other researchers confirms that this range of values is consistent with their findings. The HDFs for different regions fall within one order of magnitude for the SFBA air basin, South Coast air basin, and generic Urban regions. The latter two regions have the most similar HDFs, for each chemical emitted. The largest HDF values tend to be in the San Francisco Bay Area air basin, particularly for the cancer HDFs. This is primarily due to the relatively higher population density than any other region. The rural regions tend to have one to two orders of magnitude lower HDF values per chemical than HDFs in the San Francisco Bay Area air basin. The premature mortality HDF for PM2.5 is the highest among the HDFs considered for inhalation intake. NOx and benzene 
have similar non-cancer HDFs, while the HDF non-cancer values for $\mathrm{SO}_{2}$ are an order of magnitude lower.

It should be recognized that the EFx values as well as FFx values have significant uncertainty and variability. The EFx can range within an order of magnitude for each chemical (see Appendix B, Table B-1a and $2 \mathrm{~b}$ ). This is not surprising, as others have found that EFx related data can be highly uncertain, due to lack of knowledge and true variability in the population of exposed persons. Nishioka et al (2002) reported that the "single most influential uncertainty is the uncertainty in the concentration-response function for premature mortality." However, it is beyond the scope of this study to determine whether this is the case here, in particular to determine whether the emissions factor data are more uncertain than the premature mortality characterizations. They are both uncertain due to lack of true knowledge about their values. However, because multiple emissions factor data for certain fuel-technology power plants were available, this study was able to characterize a plausible range for the emissions estimates. In contrast, insufficient data from multiple studies was available to quantitatively characterize a range of plausible premature mortality values.

\subsection{Estimates of Disease Burden Added or Averted: Residential Attic Insulation Case Study}

The addition of residential fiberglass attic insulation is used as a case study to illustrate an application of the health benefits methodology presented here. There are two components. First, with the assumption that all electricity-heated homes in California are brought into compliance with DOE standards for attic insulation, energy savings over the assumed 50-y lifetime of the insulation are determined. These energy savings are used to determine the resulting emissions and disease burden reductions in California. In the second component, the energy requirements, emissions, and disease burden from the manufacture of fiberglass insulation required to meet the energy savings goals are determined and compared to the disease burden reduction from the use of that insulation.

\subsubsection{Energy savings and resulting emissions and disease burden reductions}

Eq. 12 in Section 2.5.1 was used to determine for each pollutant the $\mathrm{kg}$ of pollutant emissions reduction for each additional mega-tonne $(\mathrm{Mt})$ of insulation used in California. Table 12 presents a summary of the emissions eliminated in urban and rural regions, respectively, from state-wide electricity energy generating power plants due to the installation of additional fiberglass residential installation across the state. Ranges are given, due to variability in the plant efficiencies, as provided in Appendix A, Table A-1.

A number of issues arise from the results in Table 12. In the urban and rural regions, the emissions eliminated for each pollutant ranges roughly by a factor of two, depending on the power plant efficiencies assumed in the estimates. Because value ranges for efficiencies of coalpowered cogeneration plants are not provided by the database, the pollutant emissions eliminated in rural regions by upgrading insulation, are point-estimates (based on a coal plant efficiency of 0.4). As shown by Table 12, the savings from oil and WTE powered plants are at least two orders of magnitude greater in urban regions than in the rural regions. However, chemical emission saved from natural gas powered plants tend to be within the same order of magnitude in urban and rural regions. Exceptions to this are $\mathrm{NOx}$ and $\mathrm{SO}_{2}$ emissions savings, 
which tend to be more than an order of magnitude greater in urban regions. Savings of emissions from coal fired plants (including petroleum coke and crude oil fuel) are within an order of magnitude for $\mathrm{BaP}, \mathrm{PM} 2.5$ and $\mathrm{SO}_{2}$, but are an order of magnitude greater in rural than urban regions for benzene, naphthalene, and NOx emissions.

The emissions reductions in Table 12 correspond to energy savings of approximately $4.7 \times 10^{8}$ MWe-h $\left(1.7 \times 10^{18} \mathrm{~J}\right)$ over the assumed 50 year lifetime of the insulation. The savings from the different energy technologies over this 50 year period are approximately: $2.6 \times 10^{7} \mathrm{MWe}-\mathrm{h}(9.2 \times$ $\left.10^{16} \mathrm{~J}\right)$ from coal, $3.8 \times 10^{8} \mathrm{MWe}-\mathrm{h}\left(1.4 \times 10^{18} \mathrm{~J}\right)$ from natural gas, $6.3 \times 10^{7} \mathrm{MWe}-\mathrm{h}\left(2.3 \times 10^{17} \mathrm{~J}\right)$ from oil, and $2.4 \times 10^{6} \mathrm{MWe}-\mathrm{h}\left(8.7 \times 10^{15} \mathrm{~J}\right)$ from WTE technologies. These savings are not dependent on the plant efficiency assumed, but depend on the current MWe output (Energy Commission 2004) of the fuel-technology power combination in the given region.

These results are consistent with those presented by Levy et al. (2003). They estimate that adding insulation to existing single family homes throughout the US to meet the International Energy Conservation Code (IECC 2000) would save approximately $800 \mathrm{TBtu} / \mathrm{y}\left(8.4 \times 10^{17} \mathrm{~J} / \mathrm{y}\right)$ of primary energy (primarily in the southern region). For the Western US (Pacific and Mountain) region, the source savings is approximately $41 \mathrm{TBtu} / \mathrm{y}$, or $4.3 \times 10^{16} \mathrm{~J} / \mathrm{y}$ (Levy et al. 2003). By the methods of the current study, California is estimated to save nearly $3.4 \times 10^{16} \mathrm{~J} / \mathrm{y}$ if insulation was upgraded to DOE recommended levels in homes heated with electricity.

Levy et al. (2003) also estimate that the energy savings from added insulation eliminates approximately 3,100 $\mathrm{t}$ of PM2.5, 190,000 $\mathrm{t}$ of $\mathrm{SO}_{2}$ and 100,000 $\mathrm{t}$ of $\mathrm{NOx}$ per year over the entire contiguous US. In the Western US, they estimate that the quantity of these pollutants eliminated by insulation in homes heated with electricity, is approximately $210 \mathrm{t}$ of PM2.5, $8300 \mathrm{t}$ of $\mathrm{SO}_{2}$, and $7500 \mathrm{t}$ of $\mathrm{NOx}$ per year. The current study estimates that approximately $318 \mathrm{t}$ of PM2.5, 3600 $t$ of $\mathrm{SO}_{2}$ and 11,900 $t$ of $\mathrm{NOx}$ are eliminated in California per year, assuming homes heated by electrical energy install DOE recommended levels of fiberglass attic insulation The higher NOx and PM2.5 savings found in this study most likely reflect methodological differences in assessing the housing stock requiring additional insulation and in characterizing the power plant emissions. For example, Levy et al. (2003) assume 63\% of single family homes in each state had "adequate or poor insulation" and required additional insulation to meet the International Energy Conservation Code (IECC) 2000 levels, which to the authors knowledge are not as stringent as the DOE levels. This study's approach was based on using information about existing electricity-heated single family homes (distributions of housing characteristics based on housing vintage). Additionally, Levy et al. (2003) relied solely on the eGRID to estimate emissions of NOx, PM2.5 and $\mathrm{SO}_{2}$ and their emissions assumptions resulted in "lower emission rates than a capacity-based allocation," such as was used in this study. However, because of fewer coal-fired power plants in California, this study estimates lower levels of $\mathrm{SO}_{2}$ are eliminated, in comparison with the Levy et al. (2003) analysis of the Western US. 
Table 12. Ranges ${ }^{a}$ of total emission savings [kg] over 50-year assumed lifetime of fiberglass insulation in urban and rural regions [kg], respectively.

a) Urban

\begin{tabular}{|c|c|c|c|c|c|c|c|c|}
\hline & \multicolumn{2}{|c|}{ coal [kg] } & \multicolumn{2}{|c|}{ natural gas $[\mathrm{kg}]$} & \multicolumn{2}{|c|}{ Oil [kg] } & \multicolumn{2}{|c|}{ WTE $[\mathrm{kg}]$} \\
\hline & midpoint & range & midpoint & range & midpoint & range & midpoint & range \\
\hline $\mathrm{BaP}$ & $1.43 \times 10^{-1}$ & $\begin{array}{c}1.41 \times 10^{-1}- \\
1.44 \times 10^{-1}\end{array}$ & $7.7 \times 10^{2}$ & $\begin{array}{l}5.7 \times 10^{2}- \\
9.6 \times 10^{2}\end{array}$ & $1.8 \times 10^{4}$ & $\begin{array}{l}9.2 \times 10^{3}- \\
2.6 \times 10^{4}\end{array}$ & $\mathrm{n} / \mathrm{a}$ & $\mathrm{n} / \mathrm{a}$ \\
\hline benzene & $7.7 \times 10^{2}$ & $\begin{array}{c}7.3 \times 10^{2}- \\
8.1 \times 10^{2}\end{array}$ & $7.4 \times 10^{3}$ & $\begin{array}{l}5.2 \times 10^{3}- \\
9.5 \times 10^{3}\end{array}$ & $1.3 \times 10^{4}$ & $\begin{array}{l}7.0 \times 10^{3}- \\
1.9 \times 10^{4}\end{array}$ & $2.5 \times 10^{2}$ & $\begin{array}{c}1.4 \times 10^{2}- \\
3.6 \times 10^{2}\end{array}$ \\
\hline $\begin{array}{l}\text { naphthale } \\
\text { ne }\end{array}$ & 7.7 & $7.3-8.1$ & $1.1 \times 10^{3}$ & $\begin{array}{l}7.5 \times 10^{2}- \\
1.4 \times 10^{3}\end{array}$ & $9.6 \times 10^{3}$ & $\begin{array}{l}5.1 \times 10^{3}- \\
1.4 \times 10^{4}\end{array}$ & $\mathrm{n} / \mathrm{a}$ & $\mathrm{n} / \mathrm{a}$ \\
\hline $\mathrm{NOx}$ & $7.8 \times 10^{6}$ & $\begin{array}{l}7.4 \times 10^{6}- \\
8.2 \times 10^{6}\end{array}$ & $2.1 \times 10^{8}$ & $\begin{array}{l}1.4 \times 10^{8}- \\
2.8 \times 10^{8}\end{array}$ & $1.5 \times 10^{8}$ & $\begin{array}{c}8.3 \times 10^{7}- \\
2.2 \times 10^{8}\end{array}$ & $2.0 \times 10^{6}$ & $\begin{array}{c}1.1 \times 10^{6}- \\
2.9 \times 10^{6}\end{array}$ \\
\hline PM2.5 & $1.7 \times 10^{6}$ & $\begin{array}{c}1.6 \times 10^{6}- \\
1.8 \times 10^{6}\end{array}$ & $1.7 \times 10^{6}$ & $\begin{array}{c}1.3 \times 10^{6}- \\
2.1 \times 10^{6}\end{array}$ & $2.3 \times 10^{6}$ & $\begin{array}{c}1.3 \times 10^{6}- \\
3.2 \times 10^{6}\end{array}$ & $\mathrm{n} / \mathrm{a}$ & $\mathrm{n} / \mathrm{a}$ \\
\hline $\mathrm{SO}_{2}$ & $1.15 \times 10^{7}$ & $\begin{array}{c}1.1 \times 10^{7}- \\
1.2 \times 10^{7}\end{array}$ & $2.0 \times 10^{6}$ & $\begin{array}{l}1.4 \times 10^{6} \\
-2.5 \times 10^{6}\end{array}$ & $7.9 \times 10^{7}$ & $\begin{array}{c}4.7 \times 10^{7}- \\
1.1 \times 10^{8}\end{array}$ & $5.5 \times 10^{5}$ & $\begin{array}{l}3.1 \times 10^{5}- \\
7.8 \times 10^{5}\end{array}$ \\
\hline
\end{tabular}

b) Rural

\begin{tabular}{|c|c|c|c|c|c|c|c|}
\hline & $\operatorname{coal}^{\mathrm{b}}[\mathrm{kg}]$ & \multicolumn{2}{|c|}{ natural gas $[\mathrm{kg}]$} & \multicolumn{2}{|c|}{ oil $[\mathrm{kg}]$} & \multicolumn{2}{|c|}{ WTE } \\
\hline & & midpoint & range & midpoint & range & midpoint & range \\
\hline $\mathrm{BaP}$ & $1.3 \times 10^{-1}$ & $2.9 \times 10^{2}$ & $\begin{array}{c}2.1 \times 10^{2}- \\
3.7 \times 10^{2}\end{array}$ & $6.9 \times 10^{1}$ & $\begin{array}{l}3.7 \times 10^{1}- \\
1.0 \times 10^{2}\end{array}$ & $\mathrm{n} / \mathrm{a}$ & $\mathrm{n} / \mathrm{a}$ \\
\hline benzene & $4.3 \times 10^{3}$ & $1.8 \times 10^{3}$ & $\begin{array}{l}1.3 \times 10^{3}- \\
2.3 \times 10^{3}\end{array}$ & $9.6 \times 10^{1}$ & $\begin{array}{c}5.1 \times 10^{1}- \\
1.4 \times 10^{2}\end{array}$ & 1.1 & $\begin{array}{c}8.7 \times 10^{-1}- \\
1.3\end{array}$ \\
\hline $\begin{array}{l}\text { naphthale } \\
\text { ne }\end{array}$ & $4.3 \times 10^{1}$ & $2.3 \times 10^{2}$ & $\begin{array}{l}1.6 \times 10^{2}- \\
3.0 \times 10^{2}\end{array}$ & $6.4 \times 10^{1}$ & $\begin{array}{l}3.4 \times 10^{1}- \\
9.4 \times 10^{1}\end{array}$ & $\mathrm{n} / \mathrm{a}$ & $\mathrm{n} / \mathrm{a}$ \\
\hline $\mathrm{NOx}$ & $4.6 \times 10^{7}$ & $4.1 \times 10^{7}$ & $\begin{array}{c}2.8 \times 10^{7} \\
5.4 \times 10^{7}\end{array}$ & $1.0 \times 10^{6}$ & $\begin{array}{l}5.5 \times 10^{5}- \\
1.5 \times 10^{6}\end{array}$ & $7.1 \times 10^{3}$ & $\begin{array}{l}5.8 \times 10^{3}- \\
8.4 \times 10^{3}\end{array}$ \\
\hline PM2.5 & $9.4 \times 10^{6}$ & $8.6 \times 10^{5}$ & $\begin{array}{l}6.2 \times 10^{5}- \\
1.1 \times 10^{6}\end{array}$ & $1.5 \times 10^{4}$ & $\begin{array}{c}8.5 \times 10^{3}- \\
2.2 \times 10^{4}\end{array}$ & $\mathrm{n} / \mathrm{a}$ & $\mathrm{n} / \mathrm{a}$ \\
\hline $\mathrm{SO}_{2}$ & $6.3 \times 10^{7}$ & $5.1 \times 10^{5}$ & $\begin{array}{c}3.6 \times 10^{5}- \\
6.5 \times 10^{5}\end{array}$ & $5.0 \times 10^{5}$ & $\begin{array}{c}2.9 \times 10^{5}- \\
7.1 \times 10^{5}\end{array}$ & $2.3 \times 10^{3}$ & $\begin{array}{l}1.9 \times 10^{3}- \\
2.7 \times 10^{3}\end{array}$ \\
\hline
\end{tabular}

${ }^{a}$ Ranges are based on variable data on fuel-technology efficiencies

${ }^{b}$ Includes the Mohave electricity generating plant in Clarke County Nevada located on the border with California and because only one efficiency is used (0.4) no range is reported

With the emissions reductions provided by Table 12 , the next element of this study was to determine the health benefits of insulation on a functional unit basis. The functional unit selected is the mass of insulation used. Table 13 presents the estimates from this study of 
DALYs saved over an assumed lifetime of 50 years for the insulation per million metric tonne (Mt) of insulation installed. Based on the minimum and maximum emissions given in Table 12 and the uncertainty in the fuel-technology plant technology efficiencies, values in Table 13 provide the midpoint of the value range of DALYs saved per Mt. The resulting DALYs saved are between $914-1170$ DALYs/Mt insulation over 50 years (the assumed lifetime of the

Table 13. DALYs saved per Mt insulation installed. Values shown represent the midpoint of the value range based on the range of emissions given in Table 12.

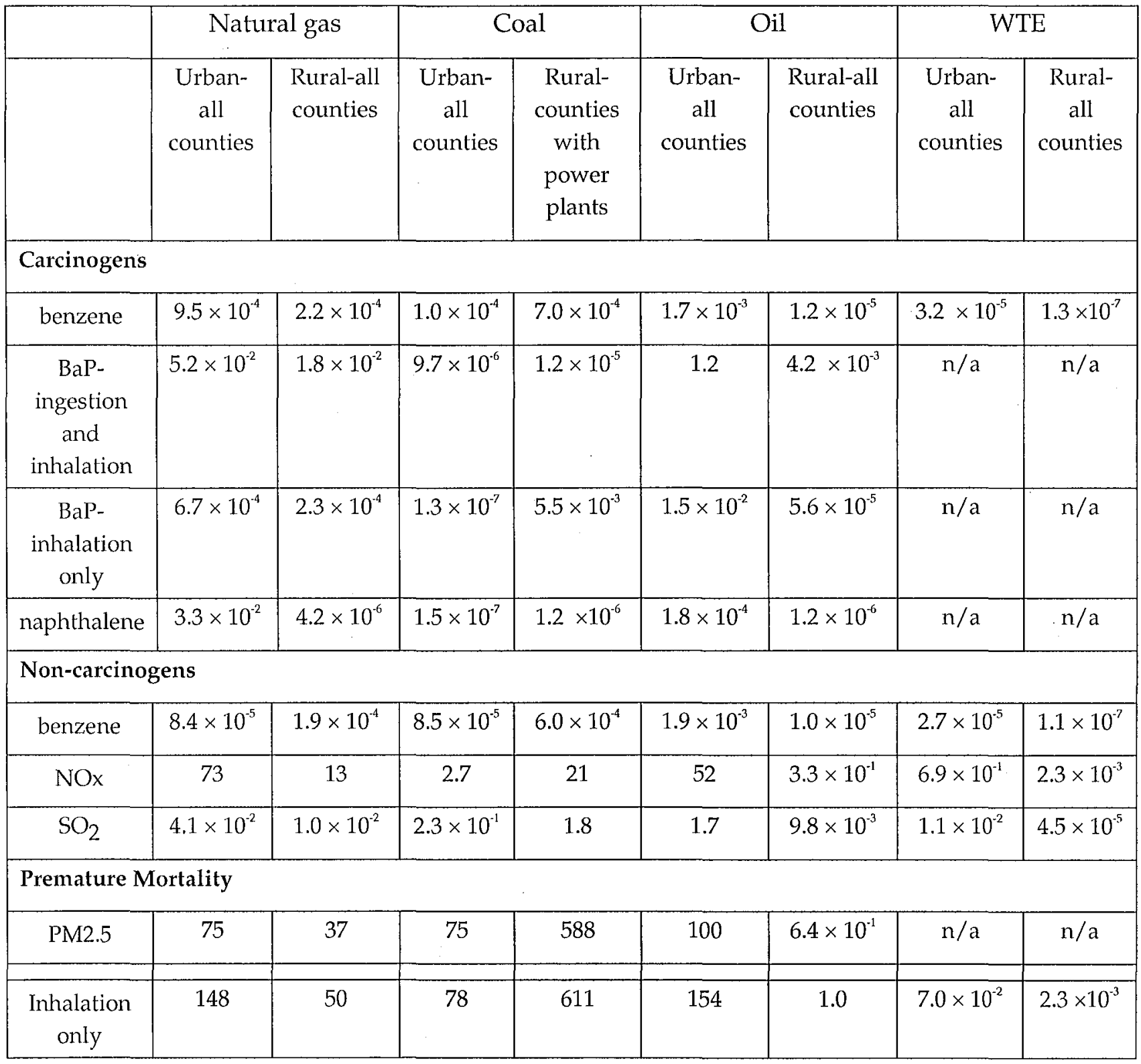


installed insulation). Due to inhalation intake, the best estimate of the DALYs saved per Mt insulation installed is 1043 DALYs (the sum of the values in the last row of Table 13). This is mostly attributable to elimination of PM2.5 emissions. Because the total insulation required to meet DOE guidelines is approximately $1.1 \mathrm{Mt}$, up to 1147 DALYs could be averted.

Because the results in Table 13 are the first attempt at characterizing the hazardous-air-pollutant (benzene, benzo(a)pyrene, and naphthalene) DALYs saved from adding residential insulation, comparisons with other studies are not possible. It is possible, however, to compare the premature deaths eliminated due to the elimination of $\mathrm{NOx}, \mathrm{SO}_{2}$, and $\mathrm{PM} 2.5$ emissions from power plants attributable to the $1.1 \mathrm{Mt}$ of insulation installed in California. Based on a published burden of disease analysis (Lvovsky 2001), approximately 10 DALYs are equivalent to 1 premature death in adults (older than 40 years of age). Thus, the results of this study indicate that approximately 115 premature deaths are averted, or 2.3 deaths per year over 50 years, due to installation of residential attic insulation in California. Approximately twenty premature deaths are attributable to reductions in NOx and approximately 96 are due to emissions reductions of PM2.5. As Table 13 displays, the most significant contribution to these health benefits are due to emissions averted from coal-powered electricity generating plants located in rural counties (primarily the Mohave coal power plant). By comparison, Levy et al. (2003), estimate that 7 premature deaths per year are averted in the Western region of the US because of emissions reductions in PM2.5, $\mathrm{SO}_{2}$, and $\mathrm{NOx}$, due to the upgrading of existing insulation in electricity-heated single-family homes to levels recommended in the IECC 2000.

\subsubsection{Emissions and energy analysis for fiberglass insulation manufacturing}

In order to address the net health benefits of end-use energy efficiency, the disease burden associated with the manufacture of the fiberglass insulation that would increase end-user efficiency was considered. This study considered both the emissions from the energy required to manufacture the insulation as well as the emissions for the insulation manufacturing process.

The electrical energy used to manufacture $1.1 \mathrm{Mt}$ of insulation is approximately $3.1 \times 10^{10} \mathrm{MJ}$ (based on an estimate of $27.9 \mathrm{MJ} / \mathrm{kg}$ for the embodied energy of fiberglass materials reported by Franklin Associates (1991). Because this amount is two orders of magnitude less than the $1.7 \times 10^{12} \mathrm{MJ}$ of electrical energy saved over the 50 -y assumed lifetime of the insulation, it was not necessary to carry out an explicit analysis of the emissions added by electrical energy to produce insulation.

In calculating emissions from insulation manufacturing, there is significant uncertainty due to the lack of information about the emissions estimates from fiberglass manufacturing. Emissions factors used in the $\mathrm{NOx}$ and $\mathrm{SO}_{2}$ estimates are required on material-manufactured basis, but they are reported on a material-processed basis in the AP-42 (EPA, 1985). Material. manufactured refers to the amount of final product (insulation) produced. Material processed refers to the amount of raw material (silica-based glass) consumed in the production of final product (fiberglass insulation). For the purposes of this screening level study, it is necessary to assume these are equivalent.

For NOx, the following manufacturing processes shown in Figure 5 have EFs available: glass melting (wool and textile) and oven curing. However, for $\mathrm{SO}_{2}$ emission factors are available for only glass melting (Wool and textile) processes. These emission factors are incorporated into the 
emissions estimates. For the other processes outlined in Figure 5, no EF data for $\mathrm{NOx}$ and $\mathrm{SO}_{2}$ is provided in the AP-42 database. Additionally, because there are almost no published emissions factors for PM2.5 from glass-fiber manufacturing, AP-42 emission factors based on organic condensable PM emissions collected at the impinger portion of a PM sampling train were applied (EPA, 1995-2000, Table 11.13.1). However, for processes shown in Figure 5, with the exception of rotary spin wool glass manufacturing (SCC 3-05-012-04), the AP-42 reports 'no data' for emissions of organic condensable PM. Therefore, this report uses the midpoint of the R-19 and R-11 rotary spin wool glass manufacturing emission factors $(3.7 \mathrm{~kg}$ organic condensable PM per Mg material processed) to estimate PM2.5 emissions from fiberglass manufacturing.

In spite of the large uncertainties, preliminary estimates of emissions were obtained and compared to results from similar studies. This study assumed that emissions associated with fiberglass manufacturing were not limited to California, but were instead assigned to a generic "urban" region of the US. Table 14 provides the estimated emissions fiberglass,i $_{\text {f }}$ from manufacturing the residential attic insulation and compares them to estimates of emissions saved from the equivalent reduction in electrical generating plant operations in California. As seen from Table 14, the magnitude of the California specific emissions eliminated are an order of magnitude greater for PM2.5 and two orders of magnitude greater for $\mathrm{NOx}$ and $\mathrm{SO}_{2^{\prime}}$ than the estimated emissions from fiberglass manufacturing.

Table 14. Estimated emissions from manufacturing $1.1 \mathrm{Mt}$ of residential attic insulation compared to emissions eliminated by reduced electricity production over 50 years

\begin{tabular}{|l|c|c|}
\hline & $\begin{array}{c}\text { Estimated } \\
\text { Emissions }_{\text {fiberglas, },}[\mathrm{kg}]\end{array}$ & $\begin{array}{c}\text { Total emissions [kg] } \\
\text { eliminated in CA }\end{array}$ \\
\hline Nox & $5.8 \times 10^{6 \mathrm{~b}}$ & $3.1 \times 10^{8}-6.1 \times 10^{8}$ \\
\hline $\mathrm{PM} 2.5$ & $5.9 \times 10^{6 \mathrm{c}}$ & $1.4 \times 10^{7}-1.8 \times 10^{7}$ \\
\hline $\mathrm{SO}_{2}$ & $5.1 \times 10^{6 \mathrm{~b}}$ & $1.2 \times 10^{8}-1.9 \times 10^{8}$ \\
\hline
\end{tabular}

"Based on urban and rural emissions ranges given in Table 12 ( $a$ and $b$ )

'EFs given per Mg material processed, and it is assumed that these apply to the $\mathrm{Mg}$ of finished product

${ }^{\text {' }}$ PM2.5 emissions are estimated from the organic condensable PM10 (i.e., that collected in the impinger portion of a PM sampling train), and these EFs are reported for rotary spin wool glass manufacturing

To determine the size of the population exposed to the fiberglass emissions and the $i F i$ for this population, this study assumed that all the fiberglass was manufactured in the contiguous US and assigned the exposure to a generic US region. The DALYs associated with pollutant emissions for each $\mathrm{Mt}$ of insulation manufactured were calculated based on Eq. 2. Table 10 provides the EFx used for NOx, PM2.5, and $\mathrm{SO}_{2}$ emissions from fiberglass manufacturing. For the fate factor FFx, that is, population-based iF, a typical $i F i$ of $10^{-13}$ is used. To determine the population to which this $i F i$ applies, the characteristic travel distance (CTD, $\mathrm{km}$ ) of each 
pollutant was determined. The CTD is the radial distance from the source where the concentration of a chemical falls to 1/e (37\%) of the concentration at the source (Bennett et al. 1998) and can be used to characterize the area with an exposed population. The formulation for the CTD is

$$
\mathrm{CTD}=\mathrm{u} / \mathrm{k}_{\mathrm{eff}}
$$

Where $u$ is the long-term average wind speed $[\mathrm{m} / \mathrm{s}]$, and $\mathrm{k}_{\text {eff }}$ is the effective reaction rate of a pollutant $\left[\mathrm{s}^{-1}\right]$ in the environment. $\mathrm{k}_{\text {eff }}$ takes into consideration partitioning and degradation of a chemical in a multimedia and can be estimated with models such as CalTOX. There are no published estimates of $\mathrm{k}_{\text {eff }}$ for PM2.5. But $\mathrm{BaP}$ is strongly particle associated. So the CTD of BaP is used as a proxy for the PM2.5 CTD, which is estimated at $30 \mathrm{~km}$. For $\mathrm{NOx}$ and $\mathrm{SO}_{2}$, which partition completely to air and undergo irreversible deposition, the CTD is simply the ratio of long-term average wind speed and reaction/deposition rates. In much of the US, long-term average wind speed is on the order of $3-4 \mathrm{~m} / \mathrm{s}$ or about $300 \mathrm{~km} / \mathrm{d}$. Removal by deposition reaction for these substances is about $3 / \mathrm{d}$, so for both $\mathrm{NOx}$ and $\mathrm{SO}_{2}$, the CTD is assumed to be on the order of $100 \mathrm{~km}$.

The area $\left(\pi \mathrm{r}^{2}\right)$ corresponding with each of these CTDs is converted to an exposed population by using an assumed population density of 27.2 persons $/ \mathrm{km}^{2}$, which is the average of the entire US (US Census Bureau, 1990). Table 15 summarizes the CTD, the area, the population size, and the resulting DALYs/Mt of insulation manufactured based on the emissions estimates from fiberglass manufacturing.

Table 15. Summary of the Characteristic Travel Distance (CTD), area, population size and DALYs/Mt insulation manufactured.

\begin{tabular}{|c|c|c|c|c|}
\hline & $\mathrm{CTD}[\mathrm{km}]$ & Area $\left[\mathrm{km}^{2}\right]$ & Population size ${ }^{a}$ & $\begin{array}{l}\text { DALYs/Mt } \\
\text { manufactured }\end{array}$ \\
\hline PM2.5 & $30^{b}$ & 2,826 & 76,867 & $5.6 \times 10^{-1}$ \\
\hline $\mathrm{NOx}$ & $100^{c}$ & 31,400 & 850,000 & $4.3 \times 10^{-2}$ \\
\hline $\mathrm{SO}_{2}$ & $100^{c}$ & 31,400 & 850,000 & $1.2 \times 10^{-3}$ \\
\hline
\end{tabular}

Assuming a population density of 27.2 persons $/ \mathrm{km}^{2}$ (US Census Bureau, 1990)

${ }^{b}$ Assuming a CTD of BaP

${ }^{\mathrm{c}}$ Realistic estimate of an exposure radius

The DALYs/Mt of insulation resulting from the manufacturing process as given in Table 15 are substantially lower (by four orders of magnitude) than the DALYs/Mt saved over $50 \mathrm{y}$ from reduced power-plant emissions attributable to this quantity of insulation. Although there are uncertainties in both the emissions and exposure calculations for the manufacturing of fiberglass insulation, these numbers indicate that there is a likely net health benefit associated with the expanded use of fiberglass insulation. Much of the uncertainty in the estimate of net 
health benefit is due to the large uncertainty about the emission factors from fiberglass manufacturing. However, others have also observed a net health benefit from the use of fiberglass insulation. In considering the premature mortality attributable to PM2.5 exposures, Nishioka et al. (2005) reported that adding insulation to new homes in the U.S. averts 60 premature deaths, or 1.2 premature deaths per year, over a 50-year period, due to reduced energy consumption (including residential combustion and power plant emissions). The primary health burden associated with supplying this insulation (approximately $0.3 \mathrm{Mt}$ of insulation) was associated with PM2.5 emissions from the manufacturing of fiberglass (mineral wool). All supply chain processes resulted in a one-time health burden of approximately 14 premature deaths for one year of increased output (Nishioka et al., 2005). 


\subsection{Conclusions and Recommendations}

Conclusions and recommendations are presented here in the context of the objectives outlined in the introduction. This report describes a definition study with the following objectives:

- provide the roadmap to organize a health benefits study for energy efficiency;

- demonstrate the use of life-cycle impact assessment (LCIA) tools such as the US Environmental Protection Agency (EPA) TRACI/CalTOX system (Bare et al. 2002) to fill in this road map; and

- provide an informative case study to illustrate how one can construct and evaluate a health benefits study for a energy-efficiency improvements in California.

To meet these project objectives, the research team employed LCIA methods that have been developed for evaluating and allocating the health and environmental impacts of energy technologies.

\subsection{Conclusions}

\subsubsection{Providing a roadmap to organize a health benefits study for energy efficiency}

This study was successful in organizing the roadmap, data, and computational tools needed to assess both disease burden and health benefits from changes in energy production and consumption in California. The framing of this problem produced a repository of important information that will be useful for future comparative studies. Among the information that has been gathered are: (1) a compilation of power plants that produce power for California along with their location and region, fuel technology, and relative contribution to power consumption; (2) emissions factors for a portfolio of energy production technologies used in California; (3) location specific emissions/exposure relationships (fate factors); and (4) a pollution-specific set of human damage functions for power plants in California.

Using this roadmap, this study characterized the current levels of atmospheric emissions and resulting health burden from six pollutants that are potential human health hazards. The magnitude and location of atmospheric emissions of $\mathrm{NOx}, \mathrm{SO}_{2}, \mathrm{PM} 2.5$, benzo(a)pyrene, benzene and naphthalene were estimated for coal, natural gas, oil and waste-to-energy fired electricity generating plants in California.

Based on this portfolio of energy production technologies, emissions rates per unit (MWe-y) of electricity production were quantified for urban and rural regions of California, as well as for the San Francisco Bay Area and South Coast air basins. Based on these emissions, chemicalspecific disease burdens were determined and compared with those averted through the introduction of an energy efficient technology. To make possible these characterizations and comparisons, relevant models and data were selected for defining the boundaries of the analysis, estimating and locating emissions, and quantifying disease burdens.

\subsubsection{Demonstrating use of life-cycle impact assessment tools to fill in this roadmap}

The researchers demonstrated the use of the LCIA tools, such as the TRACI/CalTOX approach to determine how atmospheric emissions from electricity generating plants distribute in the 
environment and what populations are impacted. Instead of a site-specific assessment, this study allocated emissions to generic urban or rural regions. Urban and rural exposure factors (emission-to-intake factors) were characterized, in addition to those for the SFBA and South Coast air basins. The source-to-dose relationships for each of these regions were quantified based on the environmental dispersion, fate, exposure and subsequent intake of the airborne chemicals using the multimedia modeling framework of CalTOX. The archetypal individual intake fraction, $i F i$, for urban exposures tends to be slightly greater than the rural exposure factors. The $i F i$ s estimated for the South Coast air basin also tracks the generic urban iF $i$ levels while the SFBA air basin $i$ Fis tend to be roughly an order of magnitude greater. The use of the CalTOX model with its ability to provide probabilistic results makes possible a process for addressing uncertainty and variability in future assessments.

Based on CalTOX, the typical (midpoint) iFi levels for urban and rural regions were converted to potential toxic effects through the human damage factor (HDF) metric. The HDF characterizes the population health burden, in units of disease affected life years (DALYs) per $\mathrm{kg}$ pollutant emitted. This study finds that inhalation HDFs resulting from electricity generating plants in California are dominated by PM2.5 exposures. The PM2.5 inhalation HDFs are at least two orders of magnitude greater than inhalation HDFs of the other chemicals.

Overall, this study was successful in demonstrating the use of the LCIA framework in assessing pollutant emissions from electricity producing plants in California and the associated noncancer and cancer disease burdens.

\subsubsection{Providing an informative case study to illustrate how one can construct and evaluate a health benefits study for energy efficiency improvements in California}

The research team was able to construct a case study on the disease burdens averted due to the installation of approximately 1.1 million metric tons $(\mathrm{Mt})$ of additional fiberglass attic insulation to reach DOE-recommended levels, in California residences. Based on a 50-year assumed lifetime of the installed insulation, the avoided disease burden is approximately 1000 DALYs from power-plant emissions per $(\mathrm{Mt})$ of insulation installed, mostly from the elimination of PM2.5 emissions. In terms of premature deaths averted, these DALYs translate to approximately 120 premature deaths averted. Approximately 20 premature deaths are attributable to reductions in NOx and approximately 100 are due to emissions reductions of PM2.5. When compared with the disease burden associated with the manufacture of this additional insulation within the LCIA framework, this study concludes that the DALYs saved per Mt insulation used are nearly four orders of magnitude greater than those associated with manufacturing the insulation.

The case study reveals the relatively significant disease burden associated with electricity generation in California through application of an LCIA framework for impact assessment. This is due in large part to emissions of NOx and PM2.5 from coal, oil, and natural gas fueled electricity-generating plants. Although existing methods for fiberglass manufacturing are quite high in particulate-matter generation, these methods still yield PM2.5 emissions far below those estimated in this report to be averted due to the addition of fiberglass insulation to existing homes in California to meet current DOE levels. 


\subsection{Commercialization Potential (not applicable)}

\subsection{Recommendations}

The demonstrated utility of an LCIA framework, such as TRACI/CalTOX, for this study supports the need to evaluate the utility of LCIA for other comparative health benefits studies. For example, this approach could also be used to assess the health benefits of fuel efficiency in the transportation sector. There is new and ongoing research in the epidemiology field indicating a significant disease burden for populations living near major roadways (Jerrett, 2005). The framework used in this study provides methods for allocating disease burden in different geographic regions. This approach would likely be informative in transportation energy use planning. The framework used here could be adapted to transportation through a one-year study that focuses on populations living near roadways. The estimated cost for this type of study is $\$ 100 \mathrm{~K}$ to $\$ 200 \mathrm{~K}$.

The successful application of LCIA methods reveals the value of exploring whether and how this approach could be applied to life-cycle studies of other energy production and energy efficiency technologies. Because the models and data for this report were developed for generic applications in life-cycle impact assessment, there is a need for research to expand, test, and support extensions of this exploratory study to other comparative energy assessments in California. This would be an ongoing support activity that could last for multiple years and would require financial support at a level of $\$ 100 \mathrm{~K}$ per year.

Estimates of PM2.5 emissions and disease burden resulting from the manufacture of fiberglass insulation are so limited by uncertainty that a formal uncertainty analysis is needed to confirm conclusions about net health benefits of using fiberglass insulation. Also there is a need to consider a broader range of pollutant emissions to assure that the PM2.5 is indeed the dominant contributor to disease burden. A formal treatment of uncertainty and variability using Monte Carlo methods could be used to establish confidence bounds around any comparative assessment. A probabilistic analysis using the existing framework would take from 1 to 2 years and cost from $\$ 100 \mathrm{~K}$ to $\$ 200 \mathrm{~K}$.

Because PM2.5 (primary fine particulate matter) dominates the potential health savings from the reduction in power plant emissions, the researchers suggest that, in addition to the uncertainty analysis recommended, priority should be given to investigating the health benefits resulting from reductions associated with secondary particulate matter, such as secondary aerosols and ozone. Research along these lines would provide much needed supplementary information to this exploratory study.

To summarize, the researchers provide the following list of potential future comparative assessment opportunities using an LCIA framework, including:

- Extending the use of the LCIA framework in this report to evaluate the health benefits due to increased end-use efficiencies and corresponding reductions of additional pollutants, such as additional PAHs, metals, ambient mercury, secondary air pollutants (NOx-ozone and $\mathrm{NOx}$-nitrate and $\mathrm{SO}_{2}$-sulfate), and greenhouse gases;

- Extending this work to the health benefits associated with decreased residential combustion heating in addition to electrical end-use efficiency associated with additional fiberglass 
insulation;

- Including morbidity in the calculation of disease burden for the general population and also to susceptible populations due to PM2.5 exposures;

- Extending this work to include health benefits to various sensitive subpopulations (in-utero, infants, elderly, asthmatics) due to reduced pollutant emissions;

- Consideration of how marginal energy use in California influences emissions reductions from end-use energy efficient technologies;

- Consideration of the economic and social costs associated with increasing end-use electricity efficient technologies;

- Consideration of the temporal potency of chemical exposure and finer spatial differences in exposure and associated health benefits;

- Comparison between traditional health risk assessment methods, such as using the RfD to assess non-cancer health effects, with estimates of the effect factor based on an ED10;

- Exploring the sources of variability and uncertainty in the input parameters for an LCIA and a systematic analysis of uncertainty in the CalTOX model structure and application. Differentiate and characterize between Type A (true variability or randomness) or B uncertainty (true variability or randomness versus lack of knowledge);

- Incorporating the LCIA methods demonstrated in this report into a full life-cycle analysis of electricity production and fiberglass manufacturing.

\subsection{Benefits to California}

By including energy efficiency in comparative assessments for the current mix of energy technologies, the results and, in particular, the methods and data of this study provide benefits to energy planning for California. Among the key benefits are

- A potential tool for more informed decision making, based on the ability to aggregate and systematically evaluate information on potential environmental implications of alternative energy systems in the context of energy efficiency choices;

- An example of how this tool could be used to make decisions about improvement options for environmental quality, by identifying optimal areas for reducing emissions/effluents, etc., on the basis of a comparative assessment of population disease burden associated with alternative supply and end-use management options; and

- An example of a more systematic approach for consideration of potential environmental and human health effects within the broader decision making process. 


\subsection{References}

Bare, J.C., Norris, G., Pennington, D.E. and McKone, T.E. (2002) "TRACI - The Tool for the Reduction and Assessment of Chemical and Other Environmental Impacts," Journal of Industrial Ecology 6(3-4):49-78.

Bennett, D., McKone, T.E., Matthies, M., Kastenberg, W. (1998) "General Formulation of Characteristic Travel Distance for Semivolatile Organic Chemicals in a Multimedia Environment,", Environmental Science and Technology 32(24): 4023-30.

Bennett, D.H., McKone, T.E., Evans, J.S., Nazaroff, W.W., Margni, M.D., Jolliet, O. and Smith, K.R. (2002a) "Defining Intake Fraction," Environmental Science E Technology 36:207A-211A.

Bennett, D.H., Margni, M.D., McKone, T.E., and Jolliet, O. (2002b) "Intake Fraction for Multimedia Pollutants: A Tool for Life Cycle Analysis and Comparative Risk Assessment," Risk Analysis 22(5): 905-918.

Burke, T.A., Doull, J., McKone, T., Paustenbach, D. Scheuplein, R., Udo de Haes, H.A., and Young, J.S. (1996) Human health impact assessment. In Life cycle assessment: Analysis by an expert panel. Washington, D.C.: ILSI Health and Environmental Sciences Institute.

CA DoF (2005) "California Statistical Abstract," California Department of Finance. Located at: http://www.dof.ca.gov/html/fs data/stat-abs/sec B.htm. Last accessed January, 2006.

Census of Population and Housing, 2000 [California]: Summary File 3 [California] [on-line data file]/ prepared by the California Digital Library, --Oakland, California: [producer and distributor], 2003. Generated by < Agnes Lobscheid > ; using Counting California; < http:/ / countingcalifornia.cdlib.org:80 >. YEAR STRUCTURE BUILT Table located specifically at: http://countingcalifornia.cdlib.org/sasbin/broker?_program=prd.calcube.sas\&study $=$ sf32000\&varMtx=H034sf32000\&dtbl=H34\&geo= cnty.

Crettaz, P., Pennington, D., Rhomberg, L., Brand, K., and Jolliet, O. (2002) "Assessing Human Health Response in Life Cycle Assessment Using ED10s and DALYs: Part 1- Cancer Effects," Risk Analysis 22(5): 931-946.

Dincer, I. (1999) "Environmental Impacts of Energy," Energy Policy 27:845-854.

Dominici, F., Peng RD, Bell M.L., Pham L., McDermott A., Zeger S.L., Samet J.M. (2006) "Fine Particulate Air Pollution and Hospital Admission for Cardiovascular and Respiratory Diseases," Journal of American Medical Association 295(10):1127-34.

DOE (2002) "Insulation Fact Sheet," Department of Energy, Assistant Secretary Energy Efficiency and Renewable Energy, DOE/CE-0180/ with Addendum 1. Prepared by the Oak Ridge National Laboratory, Oak Ridge, Tennessee 37831-6385. 19 pps.

DOE (2006). Insulation and Air Sealing information sheet. Located at: http://www.energy.gov/insulationairsealing.htm. Las accessed January, 2006.

EIA (2000) "The Market and technical potential for combined heat and power in the industrial sector". Prepared by ONSITE SYCOM Energy Corporation. 1010 Wisconsin Ave, NW Suite 340, Washington, D.C. Located at: http://www.aceee.org/industry/Resources/techpoten.pdf. Last accessed January, 2006. 
EIA (2002) "Energy Information Administration, State Electricity Profiles, 2002". Located at: http://www.eia.doe.gov/cneaf/electricity/st profiles/california.pdf. Last accessed January, 2006.

EIA (2005) "Buildings Energy Data Book" (2.1 Residential Sector Characteristics). Located at: http://buildingsdatabook.eren.doe.gov/. Last accessed January, 2006.

Energy Commission (2001) "2001 Database for Energy Efficiency Resources (DEER) Update Study" (Final Report). Prepared for The California Energy Commission (Contract Number 30099-008). Prepared by XENERGY Inc. Oakland, California. Located at:

http://www.calmac.org/publications/2001\%20DEER\%20UPDATE\%20Study.pdf . Last accessed January, 2006.

Energy Commission (2004) "2004 Database of California Power Plants," Located at: http://www.energy.ca.gov/database/index.html\#powerplants. Last accessed May, 2005.

Environmental Defense (2005) "Clearing California's Coal Shadow from the American West." Written in cooperation with the Center for Energy Efficiency and Renewable Technologies and Western Resource Advocates. Located at: http://www.ceert.org/Reports/coalreport.pdf. Last accessed January, 2006.

Environmental Defense (2006a) NOx RELs

Environmental Defense (2006b) $\mathrm{SO}_{2}$ RELs

EPA (1985) "AP 42, Fifth Edition," Volume I, Chapter 11: Mineral Products Industry, Section 11.13 Glass Fiber Manufacturing, September 1985. Located at: www.epa.gov/ttn/chief/ap42/ch11/final/c11s13.pdf. Last accessed January, 2006.

EPA (1995-2000) "AP 42, Fifth Edition, Compilation of Air Pollutant Emission Factors," Volume 1: Stationary Point and Area Sources. Located at: http://www.epa.gov/ttn/chief/ap42/. Last accessed January, 2006.

EPA (2001) "Review of Potential Efficiency Improvements at Coal-Fired Power Plants." Located at: www.epa.gov/airmarkets/fednox/126noda/heatrate_rpt_april17.pdf. Last accessed January, 2006.

EPA (2003) Emissions and Generating Resource Integrated Database (eGRID v 2.01). US EPA Office of Atmospheric Programs. Prepared by E.H. Pechan and Associates, Inc., May 2003.

ExternE (2004) Externalities of Energy, A research project of the European Commission. Reports on methods and findings are available at: http://externe.jrc.es/index.html. Last accessed January, 2006.

Franklin Associates Ltd. (1991) " Comparative Energy Evaluation of Plastic Products and their Alternatives for the Building and Construction and Transportation Industries." Prepared for the Society of the Plastics Industry.

Gold, L.S., Slone, T.H., Manley, N.B., Garfinkel, G.B. and Ames, B.N. (2005) “The Carcinogenic Potency Database (CPDB)." Located at: http://potency.berkeley.edu/cpdb.html . Last accessed January, 2006.

Guinée J, and Heijungs R. (1993) "A Proposal for The Classification of Toxic Substances Within the Framework of Life Cycle Assessment of Products," Chemosphere 26:1925-1944. 
Guinée B.J., Heijungs R., van Oers L.F.C.M, Sleeswijk A., van de Meent D., Vermeire T., Rikken M. (1996) "Inclusion of Fate in LCA Characterization of Toxic Releases Applying USES 1.0" Int. J. LCA 1:133-118.

Gulf Coast (2005) Gulf Coast Combined Heating and Power (CHP) Application Center Information. Located at http://www.gulfcoastchp.org/chp/Markets/TechPower.aspx. Last accessed June,2005.

Hertwich E.G., Pease W.S., McKone T.E. (1998) "Evaluating Toxic Impact Assessment Methods: What Works Best?" Environ. Sci. Technol. 32:A138-A144.

Hertwich, E.G., S.F. Mateles, W.S. Pease, T.E. McKone (2001) "Human Toxicity Potentials for Life Cycle Analysis and Toxics Release Inventory Risk Screening," Environmental Toxicology and Chemistry 20:928-939.

Hofstetter P. (1998) Perspectives in Life Cycle Impact Assessment: A Structured Approach to Combine Models of the Technosphere, Ecosphere and Valuesphere, Kluwer, Boston.

Huijbregts M.A.J., Thissen U., Guinee J.B., Jager T., Kalf D., van de Meent D., Ragas A.M.J., Wegener Sleeswijk A, Reijnders L. (2000) Priority Assessment of Toxic Substances in LCA I: Calculation of Toxicity Potentials for 181 Substances," Chemosphere 41:575-588.

Huijbregts, M.A.J., Rombouts, L.J.A., Ragas, M.J., van de Meent, D. (2005) "HumanToxicological Effect and Damage Factors of Carcinogenic and Noncarcinogenic Chemicals for Life Cycle Impact Assessment," Integrated Environmental Assessment and Management 1(3): 181244.

IAEA (1999) International Atomic Energy Agency, "Health and Environmental Impacts of Electricity Generation Systems: Procedures for Comparative Assessment," the International Atomic Energy Agency, Vienna, Austria.

ISO 14040 (1997). Environmental management- life cycle assessment- principles and framework. Geneva, Switzerland: International Standards Organisation (ISO).

Jerrett, M., Burnett, R.T., Ma, R., Pope, C.A., Krewski, D., Newbold, K.B., Thurston, G., Shi, Y., Finkelstein, N., Calle, E.E., and Thun, M.J. (2005) "Spatial Analysis of Air Pollution and Mortality in Los Angeles," Epidemiology 16(6): 727-736.

Khrushch, M., Worrell, E., Price, L., Martin, N., Einstein, D (1999) "Carbon Emissions Reduction Potential in the US Chemicals and Pulp and Paper Industries by Applying CHP Technologies," Energy Analysis Program, Lawrence Berkeley National Laboratory, June 1999. Located at: http://www.aceee.org/industry/Resources/khrushch.pdf. Last accessed January, 2006.

Levy, J.I., Nishioka, Y., and Spengler, J.D. (2003) "The Public Health Benefits of Insulation Retrofits in Existing Housing in the United States," Environmental Health: A Global Access Science Source 2(4): 16 pps. Located at: http://www.ehjournal.net/content/2/1/4. Last accessed January, 2006.

Lobscheid, A.B. and McKone, T.E. (2004) "Constraining Uncertainties about the Sources and Magnitude of Polycyclic Aromatic Hydrocarbon (PAH) Levels in Ambient Air: The State of Minnesota as a Case Study," Atmospheric Environment 38: 5501-5515.

Lvovsky, K (2001) "Environment Strategy Papers No. 1: Health and Environment," World Bank, October 2001. 
McKone, T.E. and MacLeod, M. (2004) "Tracking Multiple Pathways of Human Exposure to Persistent Multimedia Pollutants: Regional, Continental, and Global Scale Models," Annual Reviews of Environment and Resources 28:463-492.

Morgan, G. M.; Henrion, M. (1990) Uncertainty: A Guide to Dealing with Uncertainty in Quantitative Risk and Policy Analysis, Cambridge University Press, New York .

Nishioka, Y., Levy, J.I., Norris, G.A., Wilson, A., Hofstetter, P., and Spengler, J.D. (2002) "Integrating Risk Assessment and Life Cycle Assessment: A case Study of Insulation," Risk Analysis 22(5): 1003-1017.

Nishioka, Y., Levy, J., Norris, G.A., Bennett, D., and Spengler, J. (2005) "A Risk Based Approach to Health Impact Assessment for Input-Output Analysis, Part 2: Case Study of Insulation," The International Journal of Life Cycle Assessment 10(4): 255-262.

Ontario Hydro (1993) "Full-Cost Accounting for Decision Making," report available from Ontario Hydro, Toronto, Ontario.

ORNL (1992) Oak Ridge National Laboratory and Resources for Future, "U.S.-EC Fuel Cycle Study: Background Document to the Approach and Issues," Rep. No. 1, Oak Ridge National Lab., TN.

Pennington, D., Crettaz, P., Tauxe, A., Rhomberg, L., Brand, K., and Jolliet, O. (2002) "Assessing Human Health Response in Life Cycle Assessment Using ED10s and DALYS: Part 2- Noncancer Effects," Risk Analysis 22(5): 947-963.

Pennington, D.W., Potting, J., Finnveden, G., Lindeijer, E., Jolliet, O., Rydberg, T., and Rebitzer, G. (2004). Life cycle assessment Part 2: Current impact assessment practices. Environment International 30: 721-739.

Pope, C.A., Burnett R.T., Thun, M.J., Calle E.E., Krewski D., Ito K. and Thurston G.D. (2002). "Lung Cancer, Cardiopulmonary Mortality, and Long-Term Exposure to Fine Particulate Air Pollution." Journal of American Medical Association 287 (9): 1132-1141.

Rothman, et al., (1996). As given in the Toxicological Review of benzene (Noncancer effects). CAS No. 71-43-2. In support of Summary information on the IRIS. October 2002, US EPA EPA/635/R-02/001F. Data from p 119.

US Census Bureau (1990). Population, Housing Units, Area Measurements, and Density: 1790 to 1990. Population and Housing Unit Counts.

US Census Bureau (2004) "2004 Characteristics of New Housing," series C25 Annual. Types of Heating Fuel Used in New one-family Houses completed. Located at: http://www.census.gov/const/C25Ann/c25ann.pdf. Last accessed January, 2006. 


\subsection{Glossary and List of Acronyms}

ALC: absolute lymphocyte count

BaP: benzo(a)pyrene

BMD: benchmark dose

BW: body weight $[\mathrm{kg}]$

BR: breathing rate $[\mathrm{m} 3 / \mathrm{d}]$

CF_oral (rat $\rightarrow$ human): oral ingestion conversion factor from rat to humans

CF_oral (mouse $\rightarrow$ human): oral ingestion conversion factor from mouse to human

$\mathrm{CF}_{\mathrm{Btu} \rightarrow \mathrm{MWe}}$ : conversion factor from Btu to MWe-y $\left(3.345 \times 10^{-11}\right.$ MWe-y per Btu)

CFx: characterization factor

CHP: combined heat and power

Cogen: cogeneration plant

CTD: characteristic travel distance [km]

$\mathrm{D}_{\text {air }}:$ diffusion coefficient in air

$\mathrm{D}_{\text {water }}:$ diffusion coefficient in water

DALY: disability adjusted life year

$D A L Y_{p}$ : the sum of years of life lost due to death and disability from the cancer caused by $\mathrm{x}$ [years lost/incidence]

DEER: database for energy efficiency resources (Energy Commission, 2001)

DOE: US Department of Energy

$E D 50_{x, r}$ : the lifetime dose $[\mathrm{kg}]$ of chemical $x$ from exposure route $r$ affecting $50 \%$ of the exposed human population. $E D 50_{x, r}$ can be estimated using the TD50 from animal experiments

EF: emission factor

$\mathrm{EF}_{\text {fiberglass } \mathrm{i} i}$ emission factor of pollutant, $i$, from the manufacture of fiberglass [ $\mathrm{kg}$ pollutant/Mg insulation, finished product] 
EFx: effect factor [statistical years of life lost per mg intake of chemical $x$ ]

EIA: US Energy Information Agency

EOR: enhanced oil recovery

EPA: US Environmental Protection Agency

ESP: electrostatic precipitator

$\mathrm{FF}_{\mathrm{x}}$ : fate factor, or the population intake of chemical $x$ per unit of emission of chemical $x$ $[\mathrm{kg}$ (intake)/y per $\mathrm{kg}($ emission $) / \mathrm{y}]$

gal: gallon

GW: gigawatt

HDD: annual heating degree days $\left[{ }^{\circ} \mathrm{F}-\mathrm{d}\right]$

HDF: human damage factor

HHV: higher heating value of fuel

HV: heating value of fuel

HVAC: heating, ventilation and air conditioning

IAEA: International Atomic Energy Agency

IECC: International Energy Conservation Code

IC: internal combustion

IECC: International Energy Conservation Code

iFi: individual intake fraction

J: Joule

$\mathrm{K}_{\mathrm{d} \_\mathrm{d} / \mathrm{q} / \mathrm{s} / \mathrm{v} \text { : }}$ soil-water partition coefficient in sediment $(\mathrm{d}) /$ aquifer $(\mathrm{q}) /$ ground-soil $(\mathrm{s}) /$ vadosezone soil (v) layer

kg: kilogram

$\mathrm{K}_{\mathrm{ow}}$ : octanol-water partition coefficient 
LCA: life-cycle assessment or analysis

LCIA: life-cycle impact assessment

LHV: lower heating value of fuel

LOEL: lowest-observed effect level

MDL: method detection limit

MMBtu: million Btu

Mt: million metric tonne

MWe: mega-watt electric

MWt: thermal mega-watt

NOEL: no-observed effect level

NOx: nitrous oxides

NSPS: New Source Performance Standards

PC: pulverized coal

$p(d \mid \Delta T U$ : the probability of occurrence of a disease, $\mathrm{d}$, caused by a marginal change in the ambient toxic unit (TU) [-]

PM2.5: particulate matter with aerodynamic diameter less than $2.5 \mu \mathrm{m}$

$\mathrm{P}_{\text {vap }}$ : vapor pressure $[\mathrm{Pa}]$

$\mathrm{q}^{*}$ : the $95^{\text {th }} \%$ upper confidence bound on the linearized multistage model slope factor $\mathrm{q}_{1}$

$R_{\text {baseline }}$ : the baseline R-vlaues for homes heated with electricity reported in the 2001 DEER study

$\mathrm{R}_{\mathrm{rec}}$ : additional attic insulation needed to reach the latest DOE recommended insulation requirements

RfD: US EPA reference dose [mg/ $\mathrm{kg}-\mathrm{BW} / \mathrm{d}]$

$S_{\text {bituminous }}$ : sulfur content of bituminous coal

scf: standard cubic feet 
$S_{\text {diesel }}:$ sulfur content of diesel fuel

$\mathrm{Sd}_{\text {istillate }}:$ sulfur content of distillate oil

SFBA: San Francisco Bay Area

$\mathrm{SO}_{2}$ : sulfur dioxide

$\mathrm{S}_{\text {subbituminous: }}$ sulfur content of subbituminous coal

$\mathrm{S}_{\text {water }}$ : solubility

TAPs: toxic air pollutants

TD50: daily dose rate $[\mathrm{mg} / \mathrm{kg}(\mathrm{BW})-\mathrm{d}]$ that induces tumors in half of the test animals that would have otherwise been tumor free at no dose

$t_{\text {insulation }}:$ lifetime of the fiberglass insulation [y]

TRACI: Tool for the Reduction and Assessment of Chemicals and other environmental Impacts

$\mathrm{V}_{\text {insulation }}$ : volume of installed insulation

WTE: waste-to-energy

$\alpha$ : parameter (in addition to $\beta$ ) used to define the scaling in the beta distribution

$\beta$ : parameter (in addition to $\alpha$ ) used to define the scaling in the beta distribution

$\beta_{\text {EDIO-x }}$ : the linear low dose response slope factor [individual lifetime risk of cancer per ( $\mathrm{mg} / \mathrm{kg}$ BW-day) intake] for chemical $\mathrm{x}$, inducing a response over background of $10 \%$ for humans

$\eta e:$ electrical efficiency [-]

$\rho_{\text {fiberghass }}:$ density of fiberglass $\left(9 \mathrm{~kg} / \mathrm{m}^{3}\right)$ 
Appendix A: Tables of Data Used to Estimate Pollutant Emissions per MWe-y 
Table A-1: Ranges of electrical efficiencies $\left(\eta_{e}\right)$ of power plants, by fuel and technology type. These ranges were used to define beta distributions (with $\alpha=2 ; \beta=2$ ) to estimate emissions.

\begin{tabular}{|c|c|c|}
\hline Primary fuel & Simple cycle & $\begin{array}{c}\mathrm{CHP} / \text { cogen/ } \\
\text { Combined cycle }\end{array}$ \\
\hline Coal & $0.33-0.39^{\mathrm{a}}$ & $0.4^{\mathrm{b}}$ \\
\hline \multicolumn{3}{|l|}{ Natural gas } \\
\hline Gas turbine & $0.15-0.42^{c}$ & $0.58-0.84^{d}$ \\
\hline Steam turbine or boiler & $\begin{array}{l}0.10-0.35(<250 \mathrm{MW})^{\mathrm{e}} \\
0.25-0.45(>250 \mathrm{MW})^{\mathrm{f}}\end{array}$ & $n / a^{g}$ \\
\hline $\begin{array}{r}\begin{array}{r}\text { IC or reciprocating } \\
\text { engine }\end{array} \\
\end{array}$ & $0.25-0.50^{i}$ & $0.70-0.80^{i}$ \\
\hline \multicolumn{3}{|l|}{$\mathrm{Oil}^{\mathrm{k}}$} \\
\hline gas turbine & $0.15-0.42^{c}$ & $0.58-0.84^{\mathrm{d}}$ \\
\hline Steam turbine or boiler & $\begin{array}{l}0.10-0.35(<250 \mathrm{MW})^{\mathrm{e}} \\
0.25-0.45(>250 \mathrm{MW})^{\mathrm{f}}\end{array}$ & $\mathrm{n} / \mathrm{a}^{\mathrm{g}}$ \\
\hline $\begin{array}{r}\text { IC or reciprocating } \\
\text { engine }\end{array}$ & $0.30-0.50^{\mathrm{m}}$ & $n / a^{n}$ \\
\hline \multicolumn{3}{|l|}{\begin{tabular}{|l|l|} 
WTE $^{\circ}$ \\
\end{tabular}} \\
\hline gas turbine & $0.15-0.42^{c}$ & $0.58-0.84^{d}$ \\
\hline steam turbine or boiler & $\begin{array}{l}0.10-0.35(<250 \mathrm{MW})^{e} \\
0.25-0.45(>250 \mathrm{MW})^{\mathrm{f}}\end{array}$ & $\mathrm{n} / \mathrm{a}^{\mathrm{g}}$ \\
\hline $\begin{array}{r}\text { IC or reciprocating } \\
\text { engine }\end{array}$ & $0.25-0.50^{\mathrm{i}}$ & $0.70-0.80^{\mathrm{j}}$ \\
\hline
\end{tabular}

n/a: not applicable

"Minimum efficiency reported in EPA (2001) as 0.33-0.34 of subcritical systems, with a maximum of $5 \%$ higher efficiency with specific improvements (listed in Table 2 of EPA, 2001).

'Maximum efficiency reported in coal fired power plants (Polk Power Plant) with integrated gasification combined cycle (EPA, 2001).

"Range of simple cycle $\eta_{\mathrm{e}}$ given by AP42 (EPA, 1995-2000). Values from other references for $\eta_{\mathrm{e}}$ are within this range (Khrushch, et al, 1999; EIA, 2000; Gulf Coast, 2005).

${ }^{\mathrm{d}}$ Range of combined cycle, or cogeneration, $\eta_{\mathrm{e}} \mathrm{s}$ reported. Minimum and maximum are reported here (Khrushch, et al., 1999 and AP42, EPA, 1995-2000, respectively). Values from EIA (2000) and Gulf Coast (2005) fall within this range.

"Range of smaller steam turbines used at smaller plants which make electricity as a byproduct of delivering steam to processed or district heating systems, and smaller steam turbines used in industry or 
backpressure (non-condensing) turbines (EIA, 2000 and Gulf Coast, 2005). Assume these are plants with < 250MWe output.

${ }^{f}$ Range of upper end steam (condensing) turbines designed for large electric utility plants(EIA, 2000 and Gulf Coast, 2005). Assume these are plants with > 250MWe output.

${ }^{\mathrm{g}}$ Assumes that $\mathrm{CHP} /$ cogeneration/combined cycle refers primarily to gas turbines with steam turbines, not vice versa. If a steam turbine or boiler was reported as a cogeneration facility, assume it is a gas turbine with CHP/cogen/combined cycle technology and the associated $\eta_{e}$ value.

"Reported as $\eta_{\mathrm{e}}$ for reciprocating engines (spark ignition uses natural gas as preferred fuel and compression ignition uses diesel or other heavy fuel). Assume that these $\eta_{e} s$ apply to the plants, which report internal combustion (IC) engines as technology to generate electricity, because, like rotary engines, reciprocating engines are another class of IC engines.

' Range of natural gas fired spark ignition engine (EIA, 2000 and Gulf Coast, 2005). Low end applies to smaller stoichiometric engines, which require 3-way catalyst after treatment, and high end refers to lean burn natural gas engines.

' Range of natural gas fired reciprocating engine operating in CHP mode (Gulf Coast, 2005).

${ }^{k}$ Applies to both distillate and diesel fueled plants.

${ }^{m}$ Range of diesel fueled compression engine $\eta_{c} s$ (EIA, 2000 and Gulf Coast, 2005).

" $\eta_{e} s$ were not located. No plants in the Energy Commission database (Energy Commission, 2004) list cogeneration together with reciprocating engine technologies fueled by oil (either diesel or distillate oil).

${ }^{\circ}$ Natural gas, methane, digester or landfill gas. For those plants that are reported as having brownfield or greenfield technologies (all happen to be 'peakers' i.e., constructed to supply peak electricity demand), assume the simple cycle gas turbine plant $\eta_{e} s$ apply (the individual web sites of the plants support this assumption). 
Table A-2(a-f): Chemical emission factors used to estimate emissions from electricity generation from California power plants.

A-2a) Emission factors for $\mathrm{SO}_{2}$ emissions

\begin{tabular}{|c|c|c|c|c|}
\hline \multirow[t]{2}{*}{ Primary Fuel } & \multirow[t]{2}{*}{ Technology } & \multicolumn{3}{|c|}{ Emission Factor } \\
\hline & & Value & Units & Rating \\
\hline Coal & \multirow{3}{*}{$\begin{array}{l}\text { Bottoming cycle, topping } \\
\text { cycle, steam turbine, } \\
\text { fluidized boiler, or not } \\
\text { reported }\end{array}$} & & & \\
\hline Bituminous & & $\begin{array}{l}38 \times S_{\text {bituminous }} \\
(=19.0)^{a, b}\end{array}$ & $\mathrm{lb} /$ ton & $A$ or $B$ \\
\hline Subbituminous & & $\begin{array}{l}35 \times \mathrm{S}_{\text {subbituminous }} \\
(=17.5)^{a, c}\end{array}$ & $1 \mathrm{~b} /$ ton & $A$ or $B$ \\
\hline \multicolumn{5}{|l|}{ Oil } \\
\hline \multirow[t]{4}{*}{ Distillate } & Combustion or gas turbine & $28.3^{f}$ & lb/1000 gal oil & $\mathrm{B}$ \\
\hline & Steam turbine & & & \\
\hline & $\mathrm{MW}>30$ & $\begin{array}{l}157 \times S_{\text {distillate }} \\
(=31.4)^{e}\end{array}$ & & $\mathrm{~A}$ \\
\hline & $\mathrm{MW}<30$ & $\begin{array}{l}142 \times S_{\text {distillate }} \\
(=28.4)^{\mathrm{e}}\end{array}$ & & $\mathrm{A}$ \\
\hline Diesel & & $\begin{array}{l}142 \times S_{\text {diesel }} \\
(=56.8)^{d}\end{array}$ & lb/1000 gal oil & $\mathrm{A}$ \\
\hline \multirow[t]{3}{*}{ Natural Gas } & Combustion or gas turbine & $3.5^{\mathrm{h}}$ & $\mathrm{lb} / 10^{6} \mathrm{scf}$ & $\mathrm{B}$ \\
\hline & Steam turbine & $0.6^{\mathrm{g}}$ & $\mathrm{lb} / 10^{6} \mathrm{scf}$ & $\mathrm{A}$ \\
\hline & Reciprocating engine & $0.62^{g j}$ & $\mathrm{lb} / 10^{6} \mathrm{scf}$ & A \\
\hline \multicolumn{5}{|l|}{ WTE } \\
\hline Digester gas & $\begin{array}{l}\text { Gas turbine, combined cycle, } \\
\text { or internal combustion }\end{array}$ & $3.9^{i}$ & $\mathrm{lb} / 10^{6} \mathrm{scf}$ & $\mathrm{D}$ \\
\hline Landfill gas & $\begin{array}{l}\text { Brownfield, greenfield, } \\
\text { active flare/LFGTE, gas } \\
\text { turbine, steam turbine, } \\
\text { methane gas, internal } \\
\text { combustion, or reciprocating } \\
\text { engines. }\end{array}$ & $1.8^{\mathrm{i}}$ & $\mathrm{lb} / 10^{6} \mathrm{scf}$ & $\mathrm{C}$ \\
\hline
\end{tabular}

a It is assumed that the sulfur content of bituminous coal $\left(\mathrm{S}_{\text {bituminous }}\right)$ and subbituminous $\left(\mathrm{S}_{\text {subbituminous }}\right)$ is $0.5 \%$ (EIA, 2002), expressed as 0.5.

${ }^{\mathfrak{b}}$ Expressed as $\mathrm{SO}_{2}, \mathrm{SO}_{3}$ and gaseous sulfates. On average, $95 \%$ of fuel sulfur in bituminous coal is emitted as $\mathrm{SO}_{2}$ and only $0.7 \%$ as $\mathrm{SO}_{3}$ and gaseous sulfate. Value reported is the same for all firing configurations reported, including PC dry-bottom wall-fired firing configurations (pre-NSPS, pre-NSPS with low-NOx burner, and NSPS); PC dry bottom cell burner fired configurations; PC dry bottom tangentially fired (pre- 
NSPS, pre-NSPS with low-NOx burner, and NSPS); PC wet-bottom wall-fired (pre NSPS); PC wet-bottom tangentially fired (NSPS); cyclone furnaces; spreader stokers; and overfeed stokers.

' Expressed as $\mathrm{SO}_{2}, \mathrm{SO}_{3}$ and gaseous sulfates. Similar to bituminous coal emissions, we assume over $95 \%$ of coal is emitted as $\mathrm{SO}_{2}$. Value reported is average from all firing configurations reported, including PC dry-bottom wall-fired firing configurations (pre-NSPS and NSPS); PC dry bottom cell burner fired configurations; PC dry bottom tangentially fired (both pre-NSPS and NSPS); PC wet-bottom wall fired; cyclone furnaces; spreader stokers; and overfeed stokers.

d Because diesel is a distillate fuel, it is assumed that equivalent EFs. This EF applies only if input MW $<30$, which seems to be the case for the power plants burning diesel in the Energy Commission database. Based on sulfur content of diesel of $0.4 \%$ by weight $\left(S_{\text {diesel }}=0.4\right)$

${ }^{e}$ Sulfur weight content of distillate oil is $0.2 \%\left(S_{\text {disillate }}=0.2\right)$.

' Uncontrolled turbines (including simple cycle, regenerative cycle, cogeneration cycles and combined cycle plants) operating at greater than or equal to $80 \%$ load. EFs in the AP- 42 are given on a lb/MMBtu basis and are multiplied by the heating value of distillate fuel (Table 3 ), assuming a sulfur content of $0.2 \%$ by weight $\left(S_{\text {disitllate }}=0.2\right)$.

${ }^{g}$ Based on $100 \%$ conversion of fuel sulfur to $\mathrm{SO}_{2}$ and assuming sulfur content of 2000 grains $/ 10^{6} \mathrm{scf}$.

"Based on plants operating at or above $80 \%$ load. Because the weight content of sulfur in natural gas is not available, AP 42 recommends 3.4 E-03 lb/MMBtu multiplied by the heating value of natural gas, 1035 $\mathrm{Btu} / \mathrm{scf}$.

'Based on plants operating at or above $80 \%$ load.

${ }^{\mathrm{j}}$ Based on the average of the EFs for uncontrolled 2 stroke lean burn, 4-stroke lean and 4-stroke rich burn reciprocating engines (SCC $=2-02-002-52,2-02-002-54$, and 2-02-002-53, respectively) in AP42 (Section 3.2). EFs reported on $\mathrm{lb} / \mathrm{MMBtu}$ basis and converted to $\mathrm{lb} / 10^{6} \mathrm{scf}$ using heating value of natural gas (1020 $\mathrm{Btu} / \mathrm{scf})$. 
A-2b) Emission factors for NOx emissions

\begin{tabular}{|c|c|c|c|c|}
\hline \multirow[t]{2}{*}{ Primary Fuel } & \multirow[t]{2}{*}{ Technology } & \multicolumn{3}{|c|}{ Emission Factors } \\
\hline & & Value & Units & Rating \\
\hline Coal & \multirow{3}{*}{$\begin{array}{l}\text { Bottoming cycle, topping } \\
\text { cycle, steam turbine, } \\
\text { fluidized boiler, or not } \\
\text { reported }\end{array}$} & & & \\
\hline Bituminous & & $16.2^{\mathrm{a}}$ & $\mathrm{lb} /$ ton & $A-E$ \\
\hline Subbituminous & & $11.9^{\mathrm{b}}$ & $\mathrm{lb} /$ ton & $A-E$ \\
\hline \multicolumn{5}{|l|}{ Oil } \\
\hline \multirow[t]{2}{*}{ Distillate } & Combustion or gas turbine & $78.4^{\mathrm{e}}$ & $\mathrm{lb} / 1000 \mathrm{gal}$ & $B \& C$ \\
\hline & Steam turbine & $20^{d}$ & $\mathrm{lb} / 1000 \mathrm{gal}$ & $\mathrm{A}$ \\
\hline Diesel & & $20^{\mathrm{c}, \mathrm{d}}$ & $\mathrm{lb} / 1000 \mathrm{gal}$ & A \\
\hline \multirow[t]{5}{*}{ Natural Gas } & Combustion or gas turbine & $189.4^{\mathrm{h}}$ & $\mathrm{lb} / 10^{6} \mathrm{scf}$ & $A, D$ \\
\hline & Steam turbine & & & \\
\hline & $\mathrm{MW}>30$ & $177.5^{f}$ & $\mathrm{lb} / 10^{6} \mathrm{scf}$ & $A, D$ \\
\hline & $\mathrm{MW}<30$ & $60.7^{\mathrm{g}}$ & $\mathrm{lb} / 10^{6} \mathrm{scf}$ & $\mathrm{B}, \mathrm{C}, \mathrm{D}$ \\
\hline & Reciprocating engine & $2.5 \times 10^{3 j}$ & $\mathrm{lb} / 10^{6} \mathrm{scf}$ & $\mathrm{A}, \mathrm{B}, \mathrm{C}$ \\
\hline \multicolumn{5}{|l|}{ WTE } \\
\hline Digester gas & $\begin{array}{l}\text { Gas turbine, combined } \\
\text { cycle, or internal } \\
\text { combustion }\end{array}$ & $96^{i}$ & $\mathrm{lb} / 10^{6} \mathrm{scf}$ & $\mathrm{D}$ \\
\hline Landfill gas & $\begin{array}{l}\text { Brownfield, greenfield, } \\
\text { active flare/LFGTE, gas } \\
\text { turbine, steam turbine, } \\
\text { methane gas, internal } \\
\text { combustion, or } \\
\text { reciprocating engines. }\end{array}$ & $56^{\mathrm{i}}$ & $\mathrm{lb} / 10^{6} \mathrm{scf}$ & A \\
\hline
\end{tabular}

"Average of all boiler types reported with the exception of overfeed and underfed stokers and hand-fed units. Boiler types included are: PC dry-bottom wall-fired firing configurations (pre-NSPS and NSPS); PC dry bottom cell burner fired configurations; PC dry bottom tangentially fired (both pre-NSPS and NSPS); PC wet-bottom wall fired; cyclone furnaces; spreader stokers; overfeed stokers; and circulating bed and bubbling bed FBC.

${ }^{b}$ Average of all boiler types reported with the exception of overfeed and underfed stokers and hand-fed units. Boiler types included are: PC dry-bottom wall-fired firing configurations (pre-NSPS and NSPS); PC dry bottom cell burner fired configurations; PC dry bottom tangentially fired (both pre-NSPS and NSPS); PC wet-bottom wall fired; cyclone furnaces; spreader stokers; and circulating bed and bubbling bed FBC.

'Because diesel is a distillate oil, the same EF for distillate oil fired steam turbine was used. This is based on $\mathrm{NO}_{2}$.

${ }^{d} \mathrm{EF}$ is expressed as $\mathrm{NO}_{2^{\prime}}$ even though "over $95 \%$ of emitted $\mathrm{NOx}$ is in the form of nitrogen oxide (NO)" Section 1.3, p3 of AP-42. 
'Average of uncontrolled and water-steam injection (including simple cycle, regenerative cycle, cogeneration cycles and combined cycle plants) operating at greater than or equal to $80 \%$ load. EFs in the $\mathrm{AP}-42$ are given on a $\mathrm{bb} / \mathrm{MMBtu}$ basis and are multiplied by the heating value of distillate fuel (Table 3 ).

${ }^{\mathrm{f}}$ Expressed as $\mathrm{NO}_{2}$. EFs are the average of uncontrolled (both pre-NSPS and post-NSPS) and controlled (low-NOx burner and flue gas recirculation units) large wall-fired steam boilers with greater than $30 \mathrm{MW}$ heat input.

${ }^{\mathrm{g}}$ Expressed as $\mathrm{NO}_{2}$. EFs are the average of uncontrolled and controlled (low NOX burner and flue gas recirculation) small boilers burning less than $30 \mathrm{MW}$ heat input.

" Based on plants operating at or above $80 \%$ load. The average of three natural gas fired turbines (uncontrolled, water steam injection and lean-premix). EFs are reported on a lb/MMBtu basis and converted to $1 \mathrm{~b} / 10^{6} \mathrm{scf}$ based on heating value of natural gas.

${ }^{i}$ Based on plants operating at or above $80 \%$ load.

' Based on the average of the EFs of all of the $90-105 \%$ load and $<90 \%$ load EFs for NOx (none reported for unreported load conditions) from reciprocating engines including, 2 stroke lean burn, 4-stroke lean and 4-stroke rich burn reciprocating engines $(\mathrm{SCC}=2-02-002-52,2-02-002-54$, and 2-02-002-53, respectively in AP-42 (Section 3.2). EFs are reported on $1 \mathrm{~b} / \mathrm{MMBtu}$ basis and converted to $\mathrm{lb} / 10^{6}$ scf using heating value of natural gas $(1020 \mathrm{Btu} / \mathrm{scf})$. 
A-2c) Emission factors for PM2.5 emissions

\begin{tabular}{|c|c|c|c|c|}
\hline \multirow[t]{2}{*}{ Primary Fuel } & \multirow[t]{2}{*}{ Technology } & \multicolumn{3}{|c|}{ Emission Factors } \\
\hline & & Value & Units & Rating \\
\hline Coal & \multirow{3}{*}{$\begin{array}{l}\text { Bottoming cycle, topping } \\
\text { cycle, steam turbine, } \\
\text { fluidized boiler, or not } \\
\text { reported }\end{array}$} & & & \\
\hline Bituminous & & $0.91^{\mathrm{a}}$ & $\mathrm{lb} /$ ton & $\mathrm{C}, \mathrm{D}, \mathrm{E}$ \\
\hline Subbituminous & & $0.10^{\mathrm{b}}$ & $\mathrm{lb} /$ ton & $\mathrm{C}, \mathrm{D}, \mathrm{E}$ \\
\hline \multicolumn{5}{|l|}{ Oil } \\
\hline Diesel & & $0.54^{\mathrm{c}, \mathrm{d}}$ & lb/1000 gal & $D \& E$ \\
\hline \multirow[t]{2}{*}{ Distillate } & Steam turbine & $0.54^{d}$ & $\mathrm{lb} / 1000 \mathrm{gal}$ & $\mathrm{D} \& \mathrm{E}$ \\
\hline & Combustion and gas turbine & $1.01^{\mathrm{e}}$ & $\mathrm{lb} / 1000$ gal & $\mathrm{C}$ \\
\hline \multirow[t]{3}{*}{ Natural Gas } & Combustion or gas turbine & $4.9^{f}$ & $\mathrm{lb} / 10^{6} \mathrm{scf}$ & $\mathrm{C}$ \\
\hline & Steam turbine & negligible & & \\
\hline & Reciprocating engines & $12.8^{\mathrm{g}}$ & $\mathrm{lb} / 10^{6} \mathrm{scf}$ & $\mathrm{C}, \mathrm{D}, \mathrm{E}$ \\
\hline \multicolumn{5}{|l|}{ WTE } \\
\hline Digester gas & $\begin{array}{l}\text { Gas turbine, combined cycle, } \\
\text { or internal combustion }\end{array}$ & $\mathrm{n} / \mathrm{a}$ & & \\
\hline Landfill gas & $\begin{array}{l}\text { Brownfield, greenfield, } \\
\text { active flare/LFGTE, gas } \\
\text { turbine, steam turbine, } \\
\text { methane gas, internal } \\
\text { combustion, or reciprocating } \\
\text { engines. }\end{array}$ & $\mathrm{n} / \mathrm{a}$ & & \\
\hline
\end{tabular}

a Average of EFs from technologies reported burning bituminous coal, including PC, dry-bottom, wallfired firing configurations (for uncontrolled plants as well as plants with either multiple cyclone, scrubber, ESP, or baghouse); PC, dry bottom, tangentially fired plants which are either uncontrolled plants as well as plants with either multiple cyclone, scrubber, ESP, or baghouses); PC, wet-bottom, wallfired and tangentially fired plants that are either uncontrolled, with multiple cyclones or with ESP technology; spreader stokers which are either uncontrolled or have multiple cyclone, ESP or baghouse technology; and overfeed stokers which are either uncontrolled or have multiple cyclone technology.

${ }^{b}$ Average of EFs from technologies reported burning subbituminous coal, including PC, dry-bottom, wall-fired firing configurations (for uncontrolled plants as well as plants with either multiple cyclone, scrubber, ESP, or baghouse) and PC, dry bottom, tangentially fired plants which are either uncontrolled plants as well as plants with either multiple cyclone, scrubber, ESP, or baghouses.

'Because diesel is a distillate oil, the same EF as for PM2.5 from distillate oil fired steam turbine was used. This is based on $\mathrm{NO}_{2}$.

"The average of commercial and industrial boilers.

' Uncontrolled turbines including simple cycle, regenerative cycle, cogeneration cycles and combined cycle plants, operating at or above $80 \%$ load. 
${ }^{\mathrm{f}}$ Based on condensable PM emissions from water-steam injection gas-fired turbines. Assumes plants operate at or above $80 \%$ load.

${ }^{\mathrm{g}}$ EFs are the average of the reported filterable $(<1 \mathrm{~mm}$ aerodynamic diameter) and condensable PM2.5 from three types of reciprocating engines, including 2 stroke lean burn, 4-stroke lean and 4-stroke rich burn reciprocating engines ( $\mathrm{SCC}=2-02-002-52,2-02-002-54$, and 2-02-002-53, respectively) from the AP42. However, for the condensable PM2.5, there is no EF data available from 2-stroke lean and 4-stroke rich engines, therefore the EFs reflect emissions from 4SLB engines. Condensable PM2.5 EFs from 4-stroke lean refers to inorganic and organic PM condensable emissions. EFs are reported on $\mathrm{lb} / \mathrm{MMBtu}$ basis and converted to $\mathrm{lb} / 10^{6}$ scf using heating value of natural gas (1020 Btu/scf). 
A-2d) Emission factors for BaP emissions

\begin{tabular}{|c|c|c|c|c|}
\hline \multirow[t]{2}{*}{ Primary Fuel } & \multirow[t]{2}{*}{ Technology } & \multicolumn{3}{|c|}{ Emission Factors } \\
\hline & & Value & Units & Rating \\
\hline Coal & \multirow{3}{*}{$\begin{array}{l}\text { Bottoming cycle, topping } \\
\text { cycle, steam turbine, } \\
\text { fluidized boiler, or not } \\
\text { reported }\end{array}$} & & & \\
\hline Bituminous & & $3.8 \mathrm{E}-08^{\mathrm{a}}$ & $\mathrm{lb} /$ ton & $\mathrm{D}$ \\
\hline Subbituminous & & $3.8 \mathrm{E}-08^{\mathrm{a}}$ & $\mathrm{lb} / \mathrm{ton}$ & $\mathrm{D}$ \\
\hline \multicolumn{5}{|l|}{ Oil } \\
\hline Diesel & & $0.006^{\mathrm{b}}$ & $\mathrm{lb} / 1000 \mathrm{gal}$ & $\mathrm{C}$ \\
\hline \multirow[t]{2}{*}{ Distillate } & Steam turbine & $0.006^{\mathrm{b}}$ & $\mathrm{lb} / 1000 \mathrm{gal}$ & $\mathrm{C}$ \\
\hline & Combustion or gas turbine & $0.006^{\mathrm{c}}$ & $\mathrm{lb} / 1000 \mathrm{gal}$ & $\mathrm{C}$ \\
\hline \multirow[t]{3}{*}{ Natural Gas } & Combustion or gas turbine & $2.28 \mathrm{E}-03^{\mathrm{e}}$ & $\mathrm{lb} / 10^{6} \mathrm{scf}$ & C \\
\hline & Steam turbine & $1.2 \mathrm{E}-06^{\mathrm{d}}$ & $\mathrm{lb} / 10^{6} \mathrm{scf}$ & $\mathrm{E}$ \\
\hline & Reciprocating engine & $5.9 \mathrm{E}-06^{\mathrm{f}}$ & $\mathrm{lb} / 10^{6} \mathrm{scf}$ & $\mathrm{D}$ \\
\hline \multicolumn{5}{|l|}{ WTE } \\
\hline Digester gas & $\begin{array}{l}\text { Gas turbine, combined cycle, } \\
\text { or internal combustion }\end{array}$ & $\mathrm{n} / \mathrm{a}$ & & \\
\hline Landfill gas & $\begin{array}{l}\text { Brownfield, greenfield, active } \\
\text { flare/LFGTE, gas turbine, } \\
\text { steam turbine, methane gas, } \\
\text { internal combustion, or } \\
\text { reciprocating engines. }\end{array}$ & $\mathrm{n} / \mathrm{a}$ & & \\
\hline
\end{tabular}

${ }^{a} \mathrm{EF}$ based on plants that are either PC, dry-bottom, wall-fired and cell-burner firing configurations and Cyclone furnaces. Bituminous and subbituminous distinction not reported.

${ }^{b} \mathrm{EFs}$ are not reported in the AP-42 for diesel nor distillate oil fired steam turbine power plants. Assume that the gas-fired stationary turbines for which there are EFs are applicable. Note however, that in general, EFs from steam turbines tend to be less than half of the EFs from distillate oil gas turbine plants.

"EF reported for "PAH" and we assume that this applies to BaP (Table 3.1.4 in AP 42). Further, EFs estimated from uncontrolled turbines including simple cycle, regenerative cycle, cogeneration cycles and combined cycle plants, operating at or above $80 \%$ load.

${ }^{\mathrm{d}}$ The method detection limit (MDL). The EF is either at or below MDL.

"EFs are given for "PAH" in general (Table 3.1.3 of the AP 42) and it is assumed that this applies to BaP. EFs are based on uncontrolled gas-fired turbines operating at or above $80 \%$ load.

'Only EFs for uncontrolled 2-stroke lean burn engines (SCC 2-02-002-52) are reported in the AP42, Section 3.2. EFs are reported on $\mathrm{lb} / \mathrm{MMBtu}$ basis and converted to $\mathrm{lb} / 10^{6}$ scf using heating value of natural gas $(1020 \mathrm{Btu} / \mathrm{scf})$. 
A-2e) Emission factors for benzene emissions

\begin{tabular}{|c|c|c|c|c|}
\hline \multirow[t]{2}{*}{ Primary Fuel } & \multirow[t]{2}{*}{ Technology } & \multicolumn{3}{|c|}{ Emission Factors } \\
\hline & & Value & Units & Rating \\
\hline Coal & \multirow{3}{*}{$\begin{array}{l}\text { Bottoming cycle, topping } \\
\text { cycle, steam turbine, } \\
\text { fluidized boiler, or not } \\
\text { reported }\end{array}$} & & & \\
\hline Bituminous & & $1.3 \mathrm{E}-03^{\mathrm{a}}$ & $\mathrm{lb} /$ ton & $\mathrm{A}$ \\
\hline Sub-bituminous & & $1.3 \mathrm{E}-03^{\mathrm{a}}$ & $\mathrm{lb} /$ ton & $A$ \\
\hline \multicolumn{5}{|l|}{ Oil } \\
\hline Diesel & & $2.14 \mathrm{E}-04^{\mathrm{b}}$ & $\mathrm{lb} / 1000 \mathrm{gal}$ & C \\
\hline \multirow[t]{2}{*}{ Distillate } & Steam turbine & $2.14 \mathrm{E}-04^{\mathrm{b}}$ & $\mathrm{lb} / 1000 \mathrm{gal}$ & $\mathrm{C}$ \\
\hline & $\begin{array}{l}\text { Combustion and gas } \\
\text { turbine }\end{array}$ & $7.7 \mathrm{E}-03^{\mathrm{c}}$ & lb/1000 gal & $\mathrm{C}$ \\
\hline \multirow[t]{3}{*}{ Natural gas } & Combustion or gas turbine & $1.24 \mathrm{E}-02^{\mathrm{d}}$ & $\mathrm{lb} / 10^{6} \mathrm{scf}$ & $\mathrm{A}$ \\
\hline & Steam turbine & $2.10 \mathrm{E}-03$ & $\mathrm{lb} / 10^{6} \mathrm{scf}$ & $\mathrm{B}$ \\
\hline & Reciprocating engine & $1.4^{\mathrm{f}}$ & $1 \mathrm{~b} / 10^{6} \mathrm{scf}$ & $A \& B$ \\
\hline \multicolumn{5}{|l|}{ WTE } \\
\hline Digester gas & $\begin{array}{l}\text { Gas turbine, combined } \\
\text { cycle, or internal } \\
\text { combustion }\end{array}$ & $\mathrm{n} / \mathrm{a}$ & & \\
\hline Landfill gas & $\begin{array}{l}\text { Brownfield, greenfield, } \\
\text { active flare/LFGTE, gas } \\
\text { turbine, steam turbine, } \\
\text { methane gas, internal } \\
\text { combustion, or } \\
\text { reciprocating engines. }\end{array}$ & $8.4 \mathrm{E}-03^{\mathrm{e}}$ & $\mathrm{lb} / 10^{6} \mathrm{scf}$ & $\mathrm{B}$ \\
\hline
\end{tabular}

${ }^{\mathrm{a}} \mathrm{EF}$ based on plants that are either PC, dry-bottom, wall-fired and cell-burner firing configurations and cyclone furnaces. Bituminous and sub-bituminous distinction not reported.

${ }^{b}$ Reported for residual oil (Table 1.3-9 in AP 42) and we assume this applies for diesel and distillate oil.

' Uncontrolled turbines including simple cycle, regenerative cycle, cogeneration cycles and combined cycle plants, operating at or above $80 \%$ load.

${ }^{d}$ EFs are given for uncontrolled natural gas gas-fired turbines and are converted from $\mathrm{lb} / \mathrm{MMBtu}$. The EF assumes that a plant operates at or above $80 \%$ load.

${ }^{\text {e } F o r ~ p l a n t s ~ o p e r a t i n g ~ a t ~ o r ~ a b o v e ~} 80 \%$ load.

${ }^{f}$ Average EF reported for three types of reciprocating engines, including 2 stroke lean burn, 4-stroke lean and 4-stroke rich burn reciprocating engines ( $\mathrm{SCC}=2-02-002-52,2-02-002-54$, and 2-02-002-53, respectively) from the AP-42. EFs are reported on $\mathrm{lb} / \mathrm{MMBtu}$ basis and converted to $\mathrm{lb} / 10^{6} \mathrm{scf}$ using heating value of natural gas (1020 Btu/scf). 
A-2f) Emission factors for naphthalene emissions

\begin{tabular}{|c|c|c|c|c|}
\hline \multirow[t]{2}{*}{ Primary Fuel } & \multirow[t]{2}{*}{ Technology } & \multicolumn{3}{|c|}{ Emission Factors } \\
\hline & & Value & Units & Rating \\
\hline Coal & \multirow{3}{*}{$\begin{array}{l}\text { Bottoming cycle, topping } \\
\text { cycle, steam turbine, } \\
\text { fluidized boiler, or not } \\
\text { reported }\end{array}$} & & & \\
\hline Bituminous & & $1.3 \mathrm{E}-05^{\mathrm{a}}$ & $\mathrm{lb} /$ ton & C \\
\hline Subbituminous & & $1.3 \mathrm{E}-05^{\mathrm{a}}$ & $\mathrm{lb} /$ ton & $\mathrm{C}$ \\
\hline \multicolumn{5}{|l|}{ Oil } \\
\hline Diesel & & $1.13 \mathrm{E}-03^{\mathrm{b}}$ & $\mathrm{lb} / 1000 \mathrm{gal}$ & $\mathrm{C}$ \\
\hline \multirow[t]{2}{*}{ Distillate } & Steam turbine & $1.13 \mathrm{E}-03^{\mathrm{b}}$ & $\mathrm{lb} / 1000 \mathrm{gal}$ & $\mathrm{C}$ \\
\hline & Combustion or gas turbine & $4.9 \mathrm{E}-03^{\mathrm{c}}$ & $1 \mathrm{~b} / 1000 \mathrm{gal}$ & $\mathrm{C}$ \\
\hline \multirow[t]{3}{*}{ Natural gas } & Combustion or gas turbine & $1.35 \mathrm{E}-03^{\mathrm{d}}$ & $\mathrm{lb} / 10^{6} \mathrm{scf}$ & C \\
\hline & Steam turbine & $6.10 \mathrm{E}-04$ & $\mathrm{lb} / 10^{6} \mathrm{scf}$ & $\mathrm{E}$ \\
\hline & Reciprocating engine & $9.2 \mathrm{E}-02^{\mathrm{e}}$ & $\mathrm{lb} / 10^{6} \mathrm{scf}$ & $\mathrm{C}, \mathrm{E}$ \\
\hline \multicolumn{5}{|l|}{ WTE } \\
\hline Digester gas & $\begin{array}{l}\text { Gas turbine, combined } \\
\text { cycle, or internal } \\
\text { combustion }\end{array}$ & $\mathrm{n} / \mathrm{a}$ & & \\
\hline Landfill gas & $\begin{array}{l}\text { Brownfield, greenfield, } \\
\text { active flare/LFGTE, gas } \\
\text { turbine, steam turbine, } \\
\text { methane gas, internal } \\
\text { combustion, or } \\
\text { reciprocating engines. }\end{array}$ & $\mathrm{n} / \mathrm{a}$ & & \\
\hline
\end{tabular}

${ }^{\mathrm{a}} \mathrm{EF}$ based on plants that are either $\mathrm{PC}$, dry-bottom, wall-fired and cell-burner firing configurations and cyclone furnaces. Bituminous and subbituminous distinction not reported.

${ }^{\mathrm{b}}$ Reported for residual oil (Table 1.3-9 in AP 42) and we assume this applies for diesel and distillate oil.

"Uncontrolled turbines including simple cycle, regenerative cycle, cogeneration cycles and combined cycle plants, operating at or above $80 \%$ load.

"EFs are given for uncontrolled natural gas gas-fired turbines and are converted from $\mathrm{lb} / \mathrm{MMBtu}$. The EF assumes that a plant operates at or above $80 \%$ load.

"Average EF reported for three types of reciprocating engines, including 2 stroke lean burn, 4-stroke lean and 4-stroke rich burn reciprocating engines $(\mathrm{SCC}=2-02-002-52,2-02-002-54$, and 2-02-002-53, respectively) from the $\mathrm{AP}-42$. EFs are reported on $\mathrm{lb} / \mathrm{MMBtu}$ basis and converted to $\mathrm{lb} / 10^{6} \mathrm{scf}$ using heating value of natural gas $(1020 \mathrm{Btu} / \mathrm{scf})$. 
Table A-3: Heating value (HV) of the fuel types

\begin{tabular}{|r|c|l|l|}
\hline Fuel & HV & Units & Reference \\
\hline Coal & & & \\
\hline Bituminous ${ }^{\mathrm{a}}$ & 13,000 & $\mathrm{Btu} / \mathrm{lb}$ & App A, AP 42 \\
\hline Subbituminous & 11,900 & $\mathrm{Btu} / \mathrm{lb}$ & EIA, 2002 \\
\hline Lignite & 7200 & $\mathrm{Btu} / \mathrm{lb}$ & App A, AP 42 \\
\hline Diesel & 137,000 & Btu/gal & App A, AP 42 \\
\hline Distillate & 140,000 & Btu/gal & App A, AP 42 \\
\hline Natural gas & 1035 & Btu/scf & AP 42 \\
\hline WTE Digester gas & 600 & Btu/scf at $60^{\circ} \mathrm{F}$ & AP 42, Section 3.1 \\
\hline Landfill gas & 400 & Btu/scf at 60 ${ }^{\circ} \mathrm{F}$ & AP 42, Section 3.1 \\
\hline Crude Oil & $19,000^{\circ}$ & Btu/lb & $\begin{array}{l}\text { http:/ www.eppo.go. } \\
\text { th/ref/UNI- } \\
\text { OIL.html }\end{array}$ \\
\hline Petroleum coke & $13,300^{\mathrm{d}}$ & Btu/lb & App A, AP 42 \\
\hline
\end{tabular}

a Assumes bituminous coal burned in California

${ }^{b}$ Average of two values reported in Appendix A (p 5) and Chapter 1.4 of AP 42

${ }^{\mathrm{c}}$ Approximately $15 \%$ greater heating value than coal

'Assumes 'coke, byproduct' heating value. 
Appendix B: Intermediate Results for the Individual Intake Fraction and Effect Factors Used to Calculate Human Damage Functions (HDFs) 

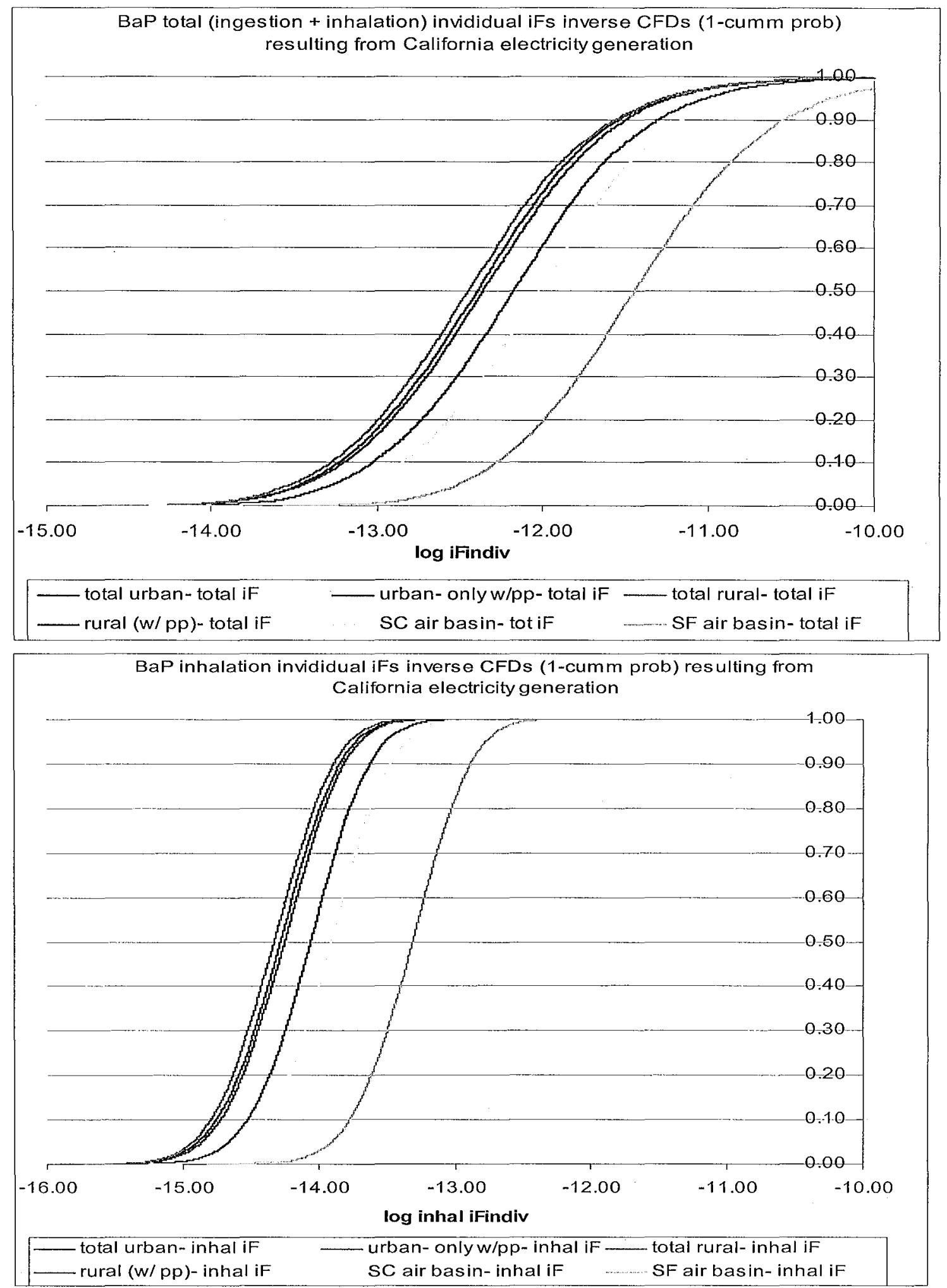

Figure B-1. Distribution of individual intake fraction (iFi) for BaP based on total (ingestion and inhalation) intake (upper chart) and intake and only inhalation intake (lower chart) 


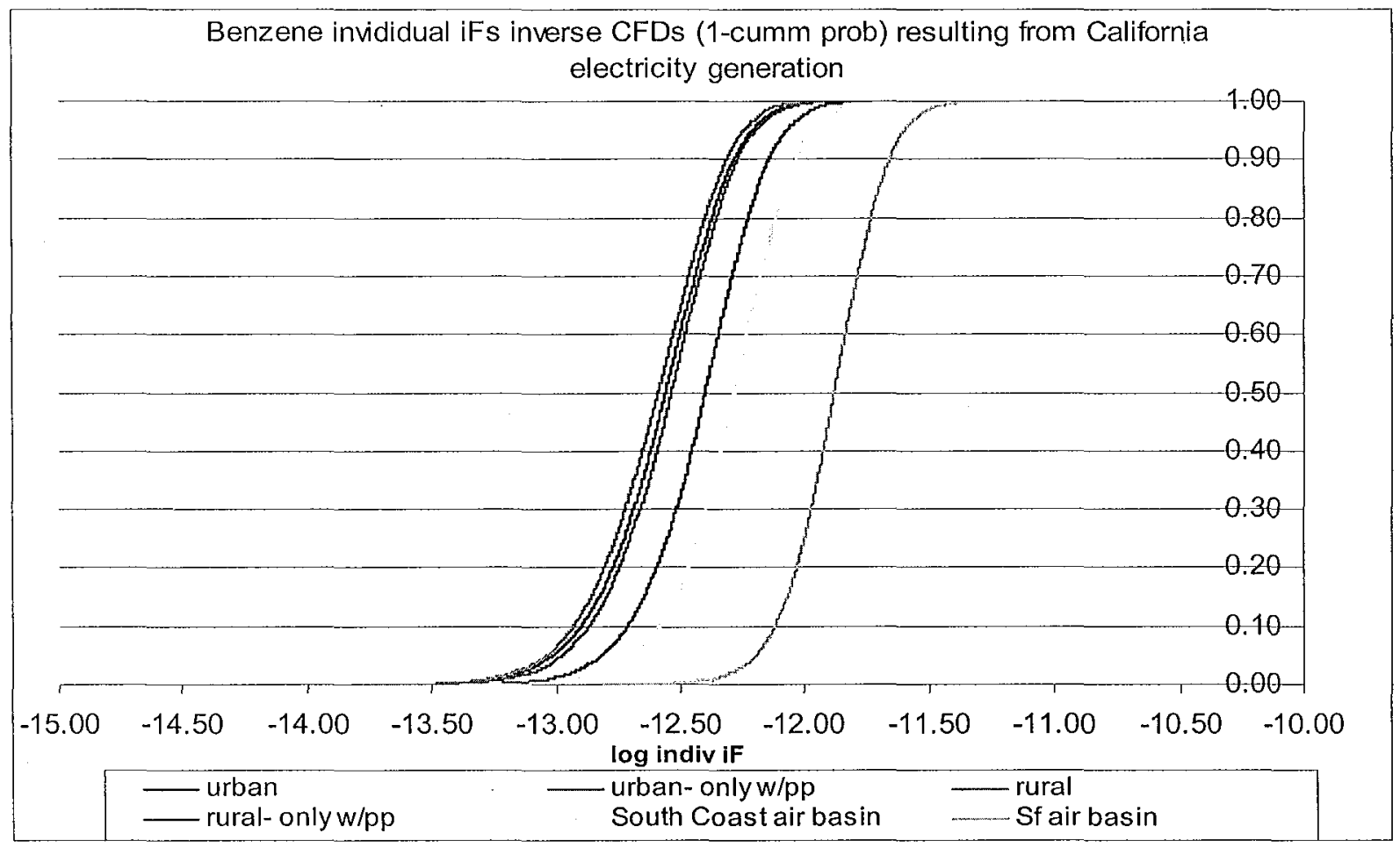

Figure B-2. Benzene iFi distributions.

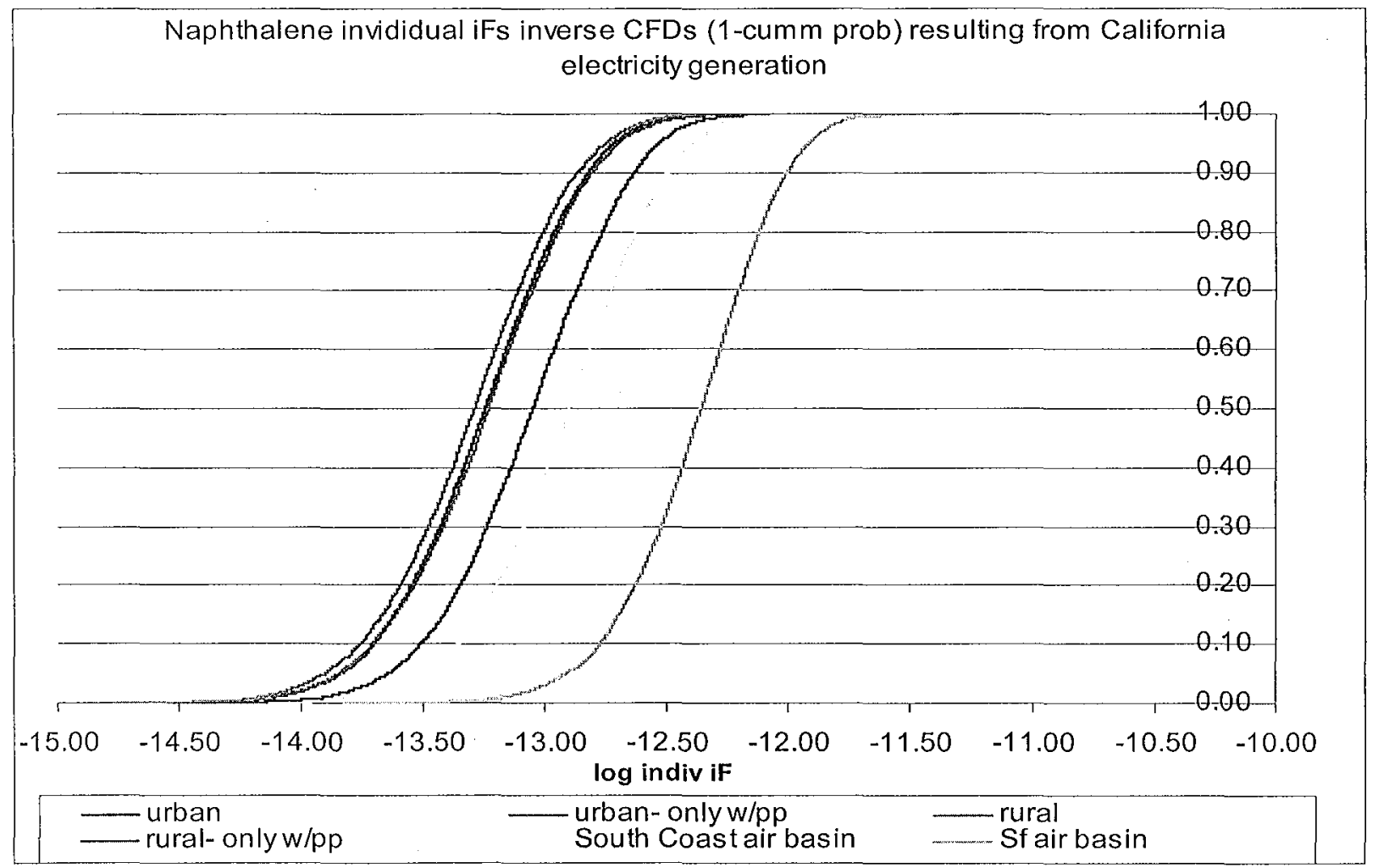

Figure B-3. Naphthalene iFi distributions 


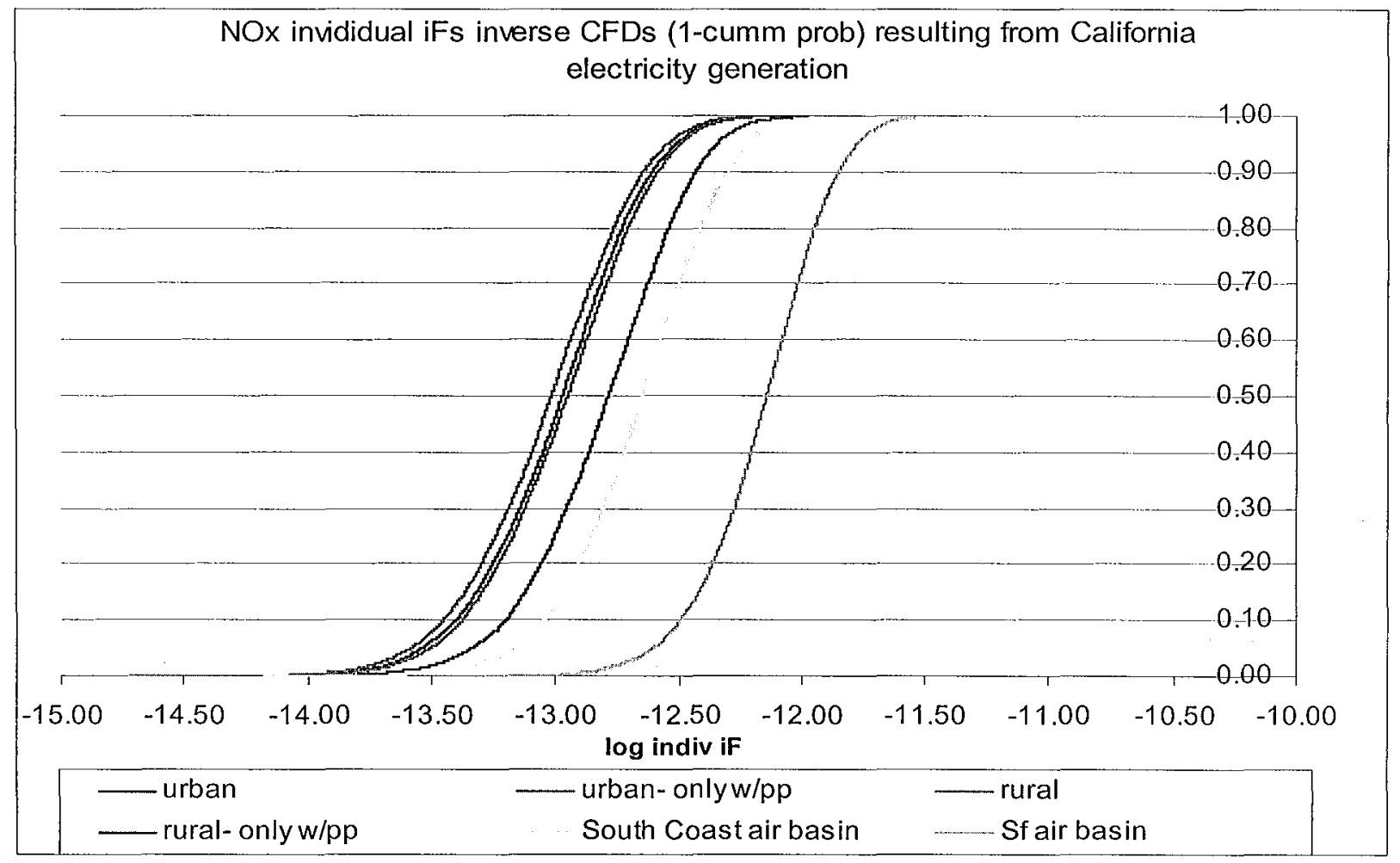

Figure B-4. NOx iFi distributions

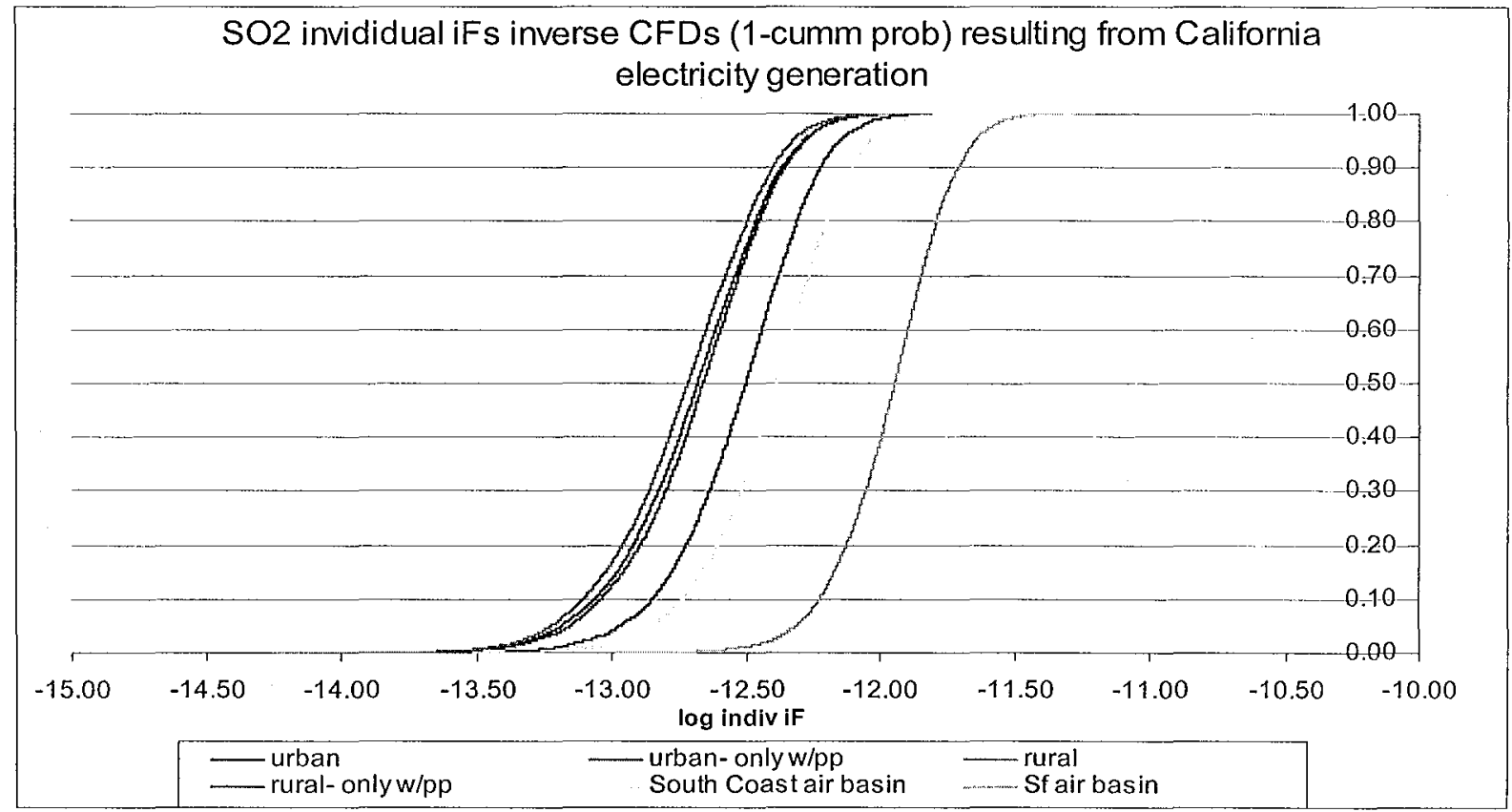

Figure $\mathrm{B}-5 . \mathrm{SO}_{2}$ iFi distributions 


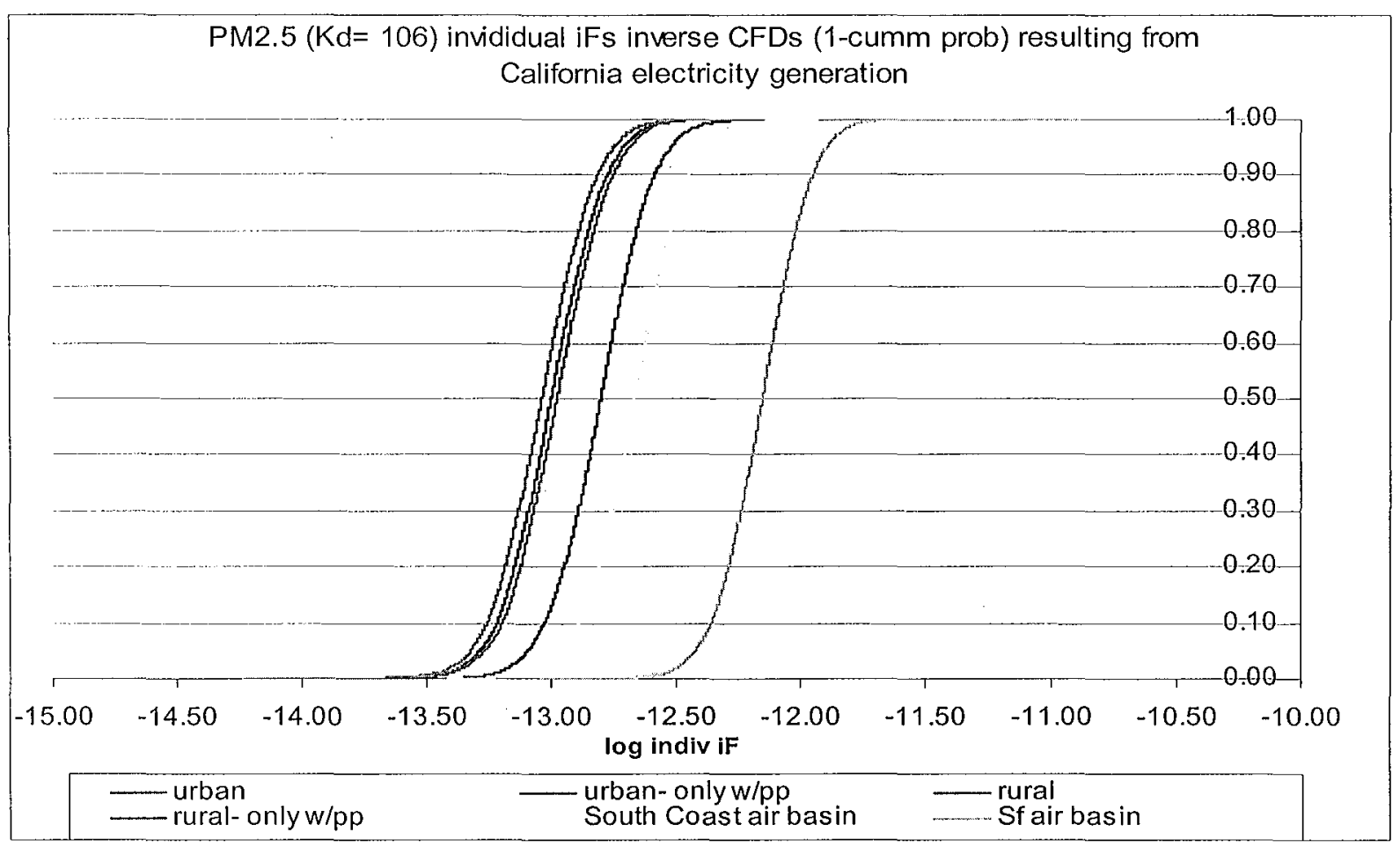

Figure B-6a. PM2.5 iFi distributions, assuming $\mathrm{Kd}=10^{6}$

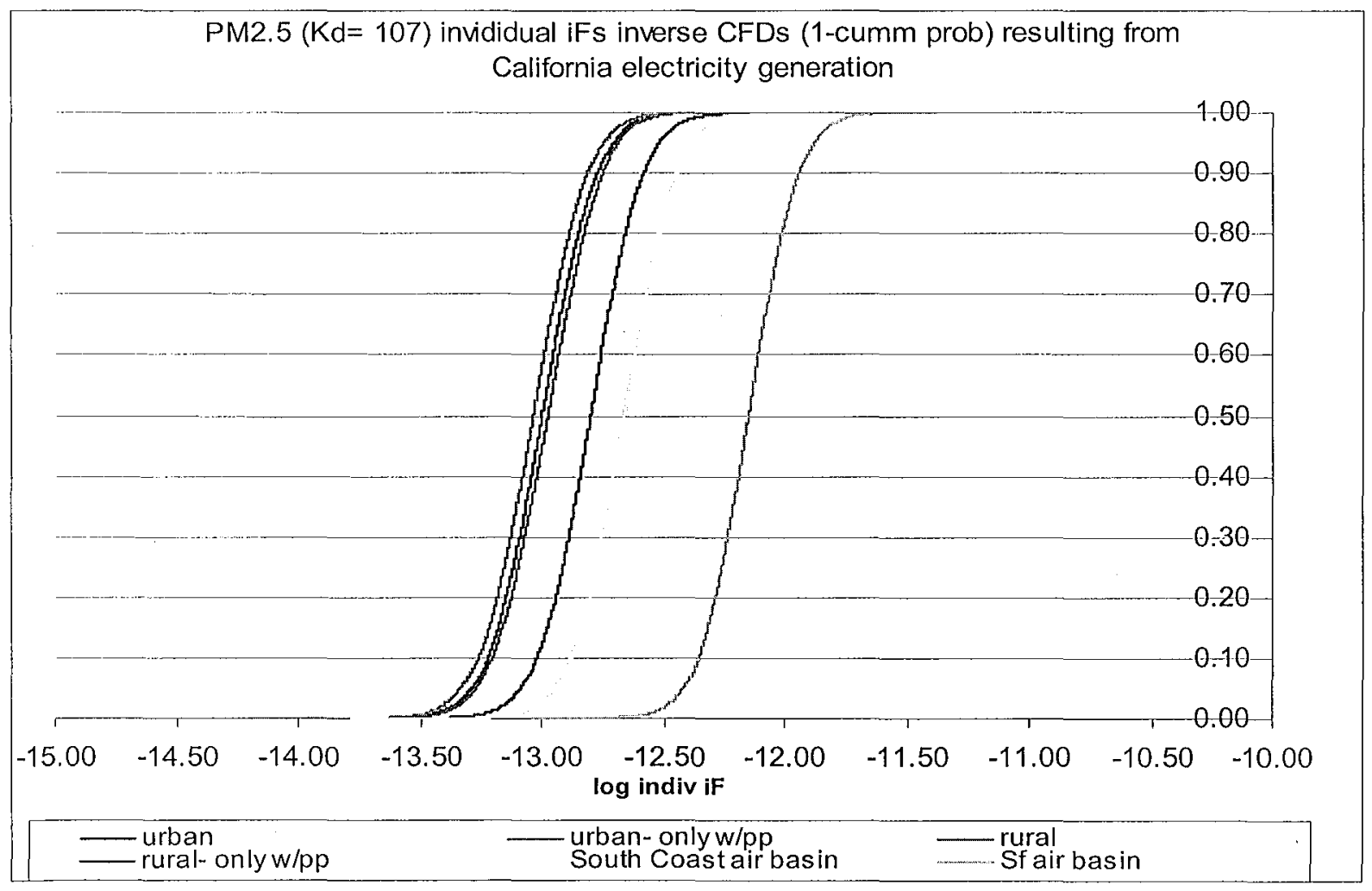

Figure B-6b: PM2.5 iFi distributions, assuming $\mathrm{Kd}=10^{7}$ 
Table B-1 (a\&b): The carcinogenic effect factor, EFx, for each chemical $x$, derived based on the methodology of a) Crettaz et al. (2002) and b) Huijbregts et al. (2005).

Table B-1a. EFx estimates based on Crettaz et al. (2002) methods using default DALYp of 6.7 y. The EFx based on specific cancer endpoint is given in parentheses (i.e., DALYp $=13.0$ for lung cancer associated with BaP exposure, and 14.6 for leukemia associated with benzene exposure)

\begin{tabular}{|c|c|c|c|}
\hline & $\begin{array}{c}\beta_{\mathrm{ED} 10 \mathrm{~h}} \\
\mathrm{risk} /(\mathrm{mg} / \mathrm{kg} \\
\mathrm{BW} / \mathrm{d})\end{array}$ & $\beta_{\mathrm{ED} 10 \mathrm{~h}}$ derivation comment & $\begin{array}{c}\text { EFx } \\
{[\text { DALY/mg }} \\
\text { intake] }\end{array}$ \\
\hline \multirow[t]{4}{*}{ benzene } & $3.9 \times 10^{-3}$ & Lower bound of range on $\mathrm{q}^{*}$ (inhalation $\rightarrow$ oral) & $\begin{array}{c}1.4 \times 10^{-8} \\
\left(3.1 \times 10^{-8}\right)\end{array}$ \\
\hline & $1.4 \times 10^{-2}$ & Upper bound of range on $\mathrm{q}^{*}$ (inhalation $\rightarrow$ oral) & $\begin{array}{c}5.1 \times 10^{-8} \\
\left(1.1 \times 10^{-7}\right)\end{array}$ \\
\hline & $2.4 \times 10^{-2}$ & ED10h from TD50a (rat); theoretical estimation & $\begin{array}{l}8.9 \times 10^{-8} \\
\left(1.9 \times 10^{-7}\right)\end{array}$ \\
\hline & $1.5 \times 10^{-2}$ & ED10h from TD50a (rat) empirical regression & $\begin{array}{c}5.5 \times 10^{-8} \\
\left(1.2 \times 10^{-7}\right)\end{array}$ \\
\hline \multirow[t]{4}{*}{$\mathrm{B}(\mathrm{a}) \mathrm{P}$} & 2.3 & Lower bound of range on $\mathrm{q} 1^{*}$ (oral) & $\begin{array}{l}8.4 \times 10^{6} \\
\left(1.6 \times 10^{.5}\right)\end{array}$ \\
\hline & 5.9 & Upper bound of range on $\mathrm{q}^{*}$ (oral) & $\begin{array}{l}2.2 \times 10^{-5} \\
\left(4.3 \times 10^{-5}\right)\end{array}$ \\
\hline & 4.2 & ED10h from TD50a (rat); theoretical estimation & $\begin{array}{c}1.6 \times 10^{-5} \\
\left(3.0 \times 10^{-5}\right)\end{array}$ \\
\hline & 2.6 & ED10h from TD50a (Rat); empirical regression & $\begin{array}{c}9.8 \times 10^{-6} \\
\left(1.9 \times 10^{-5}\right)\end{array}$ \\
\hline \multirow[t]{2}{*}{ Naphthalene } & $2.5 \times 10^{-2}$ & ED10h from TD50a (mouse); theoretical estimation & $9.2 \times 10^{-8}$ \\
\hline & $1.5 \times 10^{-2}$ & ED10h from TD50a (mouse); empirical regression & $5.7 \times 10^{-8}$ \\
\hline PM2.5 & 8.8 & $\begin{array}{l}\text { based on } 1 \mathrm{ug} / \mathrm{m} 3 \text { increase in annual PM2.5 mean } \\
\text { concentrations leading to a } 0.4 \% \text { increase in } \\
\text { premature deaths (Pope et al., 2002) }\end{array}$ & $3.1 \times 10^{-5}$ \\
\hline
\end{tabular}


Table B-1b. EFx estimates based on the methods of Huijbregts et al. (2005).

\begin{tabular}{|c|c|c|c|}
\hline & $\begin{array}{l}\text { ED50x,r } \\
{[\mathrm{kg}]}\end{array}$ & Effect Factor derivation comment & $\begin{array}{c}\text { EFx } \\
\text { [DALY/mg intake] }\end{array}$ \\
\hline \multirow[t]{4}{*}{ benzene } & 79.2 & $\begin{array}{l}\text { using specific DALYe and } \mathrm{p}(\mathrm{d} \mid \Delta \mathrm{TU}) \text { for } \\
\text { trachea, bronchus, and lung cancer } 0.026,16.5\end{array}$ & $5.4 \times 10^{-9}$ \\
\hline & & using default DALYe and $p(d \mid \Delta T U)$ for cancer & $4.4 \times 10^{-9}$ \\
\hline & 103.9 & using lower bound of $\mathrm{q}^{*}$ (inhal) reported in IRIS & $3.3 \times 10^{-9}$ \\
\hline & 29.3 & $\begin{array}{l}\text { using upper bound of } \mathrm{q}^{*} \text { (inhal) reported in } \\
\text { IRIS }\end{array}$ & $1.2 \times 10^{-8}$ \\
\hline \multirow[t]{4}{*}{$B(a) P$} & 0.4 & $\begin{array}{l}\text { using specific DALYe and } \mathrm{p}(\mathrm{d} \mid \Delta \mathrm{TU}) \text { for } \\
\text { stomach cancer }(0.035, \text { and } 13.6)\end{array}$ & $1.1 \times 10^{-6}$ \\
\hline & & using default DALYe and $\mathrm{p}(\mathrm{d} \mid \Delta \mathrm{TU})$ for cancer & $7.7 \times 10^{-7}$ \\
\hline & 0.2 & using lower bound of $\mathrm{q}^{*}$ (oral) reported in IRIS & $1.9 \times 10^{-6}$ \\
\hline & 0.1 & using upper bound of $\mathrm{q}^{*}$ (oral) reported in IRIS & $5.0 \times 10^{-6}$ \\
\hline \multirow[t]{2}{*}{ Naphthalene } & 44.9 & $\begin{array}{l}\text { using specific DALYe and } \mathrm{p}(\mathrm{d} \mid \Delta \mathrm{TU}) \text { for } \\
\text { stomach cancer }(0.035,13.6)\end{array}$ & $1.1 \times 10^{-8}$ \\
\hline & & using default DALYe and $\mathrm{p}(\mathrm{d} \mid \Delta \mathrm{TU})$ for cancer & $7.7 \times 10^{-9}$ \\
\hline PM2.5 & $4.6 \times 10^{-2}$ & using default DALYe and $\mathrm{p}(\mathrm{d} \mid \Delta \mathrm{TU})$ for cancer & $6.0 \times 10^{-6}$ \\
\hline
\end{tabular}


Attachment I: List of (A) Urban and (B) Rural Power Plants and Their Associated Fuel Type and Technology and Online MWe Sorted By County Of Location 
a) Urban power plants

\begin{tabular}{|c|c|c|c|c|c|}
\hline PLANTNAME & PRIMARY FUEL & TECHNOLOGY & COGEN & COUNTY & $\begin{array}{l}\text { ONLINE } \\
\text { MW }\end{array}$ \\
\hline Oakland & Distillate Oil & Gas Turbine & $\begin{array}{l}\text { Not } \\
\text { Cogen }\end{array}$ & Alameda & 165 \\
\hline Alameda & Natural Gas & Combustion Turbine & $\begin{array}{l}\text { Not } \\
\text { Cogen }\end{array}$ & Alameda & 51.65 \\
\hline $\begin{array}{l}\text { Stanford Energy } \\
\text { Group }\end{array}$ & Natural Gas & & Cogen & Alameda & 0.115 \\
\hline Borden Chemical & Natural Gas & & Cogen & Alameda & 0.2 \\
\hline $\begin{array}{l}\text { Summit Medical } \\
\text { Cogen }\end{array}$ & Natural Gas & & Cogen & Alameda & 2.86 \\
\hline $\begin{array}{l}\text { Continental Can - } \\
\text { White Cap }\end{array}$ & Natural Gas & & $\begin{array}{l}\text { Not } \\
\text { Cogen }\end{array}$ & Alameda & 0.6 \\
\hline PE - Berkeley Inc. & $\begin{array}{l}\text { Natural Gas, } \\
\text { Distill }\end{array}$ & Combined Cycle & Cogen & Alameda & 28.5 \\
\hline \begin{tabular}{|l|} 
Altamont Gas \\
Recovery
\end{tabular} & Landfill Gas & Active -Flare/Lfgte & $\begin{array}{l}\text { Not } \\
\text { Cogen }\end{array}$ & Alameda & 7 \\
\hline $\begin{array}{l}\text { Gas Recovery } \\
\text { Systems - Fremont }\end{array}$ & Msw & Landfill Gas & $\begin{array}{l}\text { Not } \\
\text { Cogen }\end{array}$ & Alameda & 3.75 \\
\hline Oroville Cogen & Natural Gas & Gas Turbine & Cogen & Butte & 8.05 \\
\hline $\begin{array}{l}\text { Pacific Oroville } \\
\text { Power Inc. }\end{array}$ & \begin{tabular}{|l} 
Ag. \& \\
Woodwaste
\end{tabular} & & $\begin{array}{l}\text { Not } \\
\text { Cogen }\end{array}$ & Butte & 18.75 \\
\hline $\begin{array}{l}\text { Nichols Road Power } \\
\text { Plant }\end{array}$ & $\begin{array}{l}\text { Pet Coke, Crude } \\
\text { Oil }\end{array}$ & Fluidized Boiler & $\begin{array}{l}\text { Not } \\
\text { Cogen }\end{array}$ & Contra Costa & 19 \\
\hline $\begin{array}{l}\text { Wilbur West Power } \\
\text { Plant }\end{array}$ & $\begin{array}{l}\text { Pet Coke, Crude } \\
\text { Oil }\end{array}$ & Fluidized Boiler & $\begin{array}{l}\text { Not } \\
\text { Cogen }\end{array}$ & Contra Costa & 19 \\
\hline $\begin{array}{l}\text { Loveridge Road } \\
\text { Power Plant }\end{array}$ & $\begin{array}{l}\text { Pet Coke, Crude } \\
\text { Oil }\end{array}$ & Fluidized Boiler & $\begin{array}{l}\text { Not } \\
\text { Cogen }\end{array}$ & Contra Costa & 19 \\
\hline \begin{tabular}{|l} 
East Third Street \\
Power Plant
\end{tabular} & $\begin{array}{l}\text { Pet Coke, Crude } \\
\text { Oil }\end{array}$ & Fluidized Boiler & $\begin{array}{l}\text { Not } \\
\text { Cogen }\end{array}$ & Contra Costa & 19 \\
\hline $\begin{array}{l}\text { Wilbur East Power } \\
\text { Plant }\end{array}$ & $\begin{array}{l}\text { Pet Coke, Crude } \\
\text { Oil }\end{array}$ & Steam Turbine & $\begin{array}{l}\text { Not } \\
\text { Cogen }\end{array}$ & Contra Costa & 19 \\
\hline
\end{tabular}


a) Urban power plants (continued)

\begin{tabular}{|c|c|c|c|c|c|}
\hline PLANTNAME & PRIMARY FUEL & TECHNOLOGY & COGEN & COUNTY & $\begin{array}{l}\text { ONLINE } \\
\text { MW }\end{array}$ \\
\hline $\begin{array}{l}\text { Los Medanos Energy } \\
\text { Center }\end{array}$ & Natural Gas & $\begin{array}{l}\text { Cogeneration, Steam To } \\
\text { Uss-Posco }\end{array}$ & $\begin{array}{l}\text { Not } \\
\text { Cogen }\end{array}$ & Contra Costa & 555 \\
\hline Delta Energy Center & Natural Gas & $\begin{array}{l}\text { Combined Cycle } \\
\text { Cogeneration Steam To } \\
\text { Dow }\end{array}$ & Cogen & Contra Costa & 861 \\
\hline Mobile Gt & Natural Gas & $\begin{array}{l}\text { Gas Combustion } \\
\text { Turbine }\end{array}$ & $\begin{array}{l}\text { Not } \\
\text { Cogen }\end{array}$ & Contra Costa & 45 \\
\hline Chevron - Concord & Natural Gas & Gas Turbine & Cogen & Contra Costa & 3 \\
\hline $\begin{array}{l}\text { Foster-Wheeler } \\
\text { Martinez Cogen L.P. }\end{array}$ & Natural Gas & Gas Turbine & Cogen & Contra Costa & 113.5 \\
\hline Crockett Cogen & Natural Gas & Gas Turbine & Cogen & Contra Costa & 247.4 \\
\hline $\begin{array}{l}\text { Riverview Energy } \\
\text { Center }\end{array}$ & Natural Gas & Gas Turbine & & Contra Costa & 47.3 \\
\hline Richmond Cogen & Natural Gas & Gas Turbine Turbine & Cogen & Contra Costa & 125.28 \\
\hline $\begin{array}{l}\text { Martinez Refining } \\
\text { Co. }\end{array}$ & Natural Gas & $\begin{array}{l}\text { Gas Turbine, Steam } \\
\text { Turbine }\end{array}$ & Cogen & Contra Costa & 99 \\
\hline $\begin{array}{l}\text { Rhone-Poulenc - } \\
\text { Stauffer Chemical }\end{array}$ & Natural Gas & $\begin{array}{l}\text { Gas Turbine/Heat } \\
\text { Recovery Steam } \\
\text { Generatr }\end{array}$ & Cogen & Contra Costa & 4 \\
\hline Brookside Hospital & Natural Gas & Internal Combustion & Cogen & Contra Costa & 0.949 \\
\hline C \& H Sugar & Natural Gas & $\begin{array}{l}\text { Steam Turbine, Waste } \\
\text { Heat }\end{array}$ & Cogen & Contra Costa & 9.5 \\
\hline Contra Costa & Natural Gas & Steam Turbine & $\begin{array}{l}\text { Not } \\
\text { Cogen }\end{array}$ & Contra Costa & 672 \\
\hline Pittsburg & Natural Gas & Steam Turbine & $\begin{array}{l}\text { Not } \\
\text { Cogen }\end{array}$ & Contra Costa & 1332 \\
\hline City Of Concord & Natural Gas & & Cogen & Contra Costa & 0.105 \\
\hline Tosco Sfar Carbon & Natural Gas & & Cogen & Contra Costa & 27.38 \\
\hline $\begin{array}{l}\text { San Francisco } \\
\text { Refinery }\end{array}$ & Natural Gas & & Cogen & Contra Costa & 49.9 \\
\hline
\end{tabular}


a) Urban power plants (continued)

\begin{tabular}{|c|c|c|c|c|c|}
\hline PLANTNAME & PRIMARY FUEL & TECHNOLOGY & COGEN & COUNTY & $\begin{array}{c}\text { ONLINE } \\
\text { MW }\end{array}$ \\
\hline Calpine Pittsburg & $\begin{array}{l}\text { Natural Gas, } \\
\text { Hydro }\end{array}$ & Gas Turbine & Cogen & Contra Costa & 74 \\
\hline Nove Power Plant & Landfill Gas & Internal Combustion & $\begin{array}{l}\text { Not } \\
\text { Cogen }\end{array}$ & Contra Costa & 3 \\
\hline Fresno Cogen & Natural Gas & Combined Cycle & Cogen & Fresno & 25 \\
\hline Saint Agnes Hospital & Natural Gas & Gas Turbine & Cogen & Fresno & 2.325 \\
\hline Al Resources & Natural Gas & $\begin{array}{l}\text { Gas Turbine/Heat } \\
\text { Recovery Steam } \\
\text { Generatr }\end{array}$ & Cogen & Fresno & 8.5 \\
\hline Coalinga & Natural Gas & $\begin{array}{l}\text { Gas Turbine/Heat } \\
\text { Recovery Steam } \\
\text { Generatr }\end{array}$ & Cogen & Fresno & 20.7 \\
\hline $\begin{array}{l}\text { Fresno Cogen } \\
\text { Partners Lp Pkr }\end{array}$ & Natural Gas & & Cogen & Fresno & 21.3 \\
\hline Sanger Power \& Feed & Natural Gas & & Cogen & Fresno & 39.8 \\
\hline Roy Sharp Jr. & Natural Gas & & $\begin{array}{l}\text { Not } \\
\text { Cogen }\end{array}$ & Fresno & 0.1 \\
\hline $\begin{array}{l}\text { Wellhead Power } \\
\text { Gates, Llc }\end{array}$ & Natural Gas & & $\begin{array}{l}\text { Not } \\
\text { Cogen }\end{array}$ & Fresno & 46.5 \\
\hline $\begin{array}{l}\text { Wellhead Power } \\
\text { Panoche, Llc }\end{array}$ & Natural Gas & & $\mid \begin{array}{l}\text { Not } \\
\text { Cogen }\end{array}$ & Fresno & 49.9 \\
\hline $\begin{array}{l}\text { Calpeak Power } \\
\text { Panoche, Llc }\end{array}$ & Natural Gas & & & Fresno & 49.615 \\
\hline $\begin{array}{l}\text { Pe - Kes Kingsburg } \\
\text { Llc }\end{array}$ & $\begin{array}{l}\text { Natural Gas, } \\
\text { Distill }\end{array}$ & & Cogen & Fresno & 34.5 \\
\hline Coalinga Cogen Co. & Natural Gas/Eor & Gas Turbine & Cogen & Fresno & 38 \\
\hline Rio Bravo Fresno & Woodwaste & Steam Turbine & $\begin{array}{l}\text { Not } \\
\text { Cogen }\end{array}$ & Fresno & 24.3 \\
\hline $\begin{array}{l}\text { Mendota Biomass } \\
\text { Power Ltd }\end{array}$ & Woodwaste & Steam Turbine, $\mathrm{Cfb}$ & Cogen & Fresno & 25 \\
\hline Hanford & Petroleum Coke, & Fluidized Boiler & Cogen & Kings & 24 \\
\hline
\end{tabular}


a) Urban power plants (continued)

\begin{tabular}{|c|c|c|c|c|c|}
\hline PLANTNAME & PRIMARY FUEL & TECHNOLOGY & COGEN & COUNTY & $\begin{array}{l}\text { ONLINE } \\
\text { MW }\end{array}$ \\
\hline & Crud & & & & \\
\hline $\begin{array}{l}\text { Kings County State } \\
\text { Prison }\end{array}$ & Natural Gas & & Cogen & Kings & 5.2 \\
\hline Gwf Henrietta & Natural Gas & & $\begin{array}{l}\text { Not } \\
\text { Cogen }\end{array}$ & Kings & 96 \\
\hline Gwf Hanford Peaker & Natural Gas & Brown Field & $\mid \begin{array}{l}\text { Not } \\
\text { Cogen }\end{array}$ & Kings & 95 \\
\hline Dinuba Energy Inc. & \begin{tabular}{|l} 
Ag. \& \\
Woodwaste
\end{tabular} & & Cogen & Kings & 12 \\
\hline $\begin{array}{l}\text { Arco Wilmington } \\
\text { Calciner }\end{array}$ & Petroleum Coke & $\begin{array}{l}\text { Coal Fired Bottoming } \\
\text { Cycle }\end{array}$ & Cogen & Los Angeles & 35.8 \\
\hline Pebbly Beach & Diesel & Internal Combustion & $\begin{array}{l}\text { Not } \\
\text { Cogen }\end{array}$ & Los Angeles & 9.4 \\
\hline Diesels & Diesel & & $\begin{array}{l}\text { Not } \\
\text { Cogen }\end{array}$ & Los Angeles & 26 \\
\hline $\begin{array}{l}\text { Alamitos Generating } \\
\text { Station }\end{array}$ & Distillate Oil & $\begin{array}{l}\text { Steam Turbine, Gas } \\
\text { Turbine }\end{array}$ & $\begin{array}{l}\text { Not } \\
\text { Cogen }\end{array}$ & Los Angeles & 2087 \\
\hline Cotija Cheese & Natural Gas & Xeration & Cogen & Los Angeles & 0.12 \\
\hline Linde Wilmington & Natural Gas & Combined Cycle & Cogen & Los Angeles & 28 \\
\hline Harbor & Natural Gas & $\begin{array}{l}\text { Combined Cycle, Gas } \\
\text { Turbine }\end{array}$ & Cogen & Los Angeles & 472 \\
\hline Lundy - Thagard Oil & Natural Gas & $\begin{array}{l}\text { Combined } \\
\text { Cycle/Topping Cycle }\end{array}$ & Cogen & Los Angeles & 1.4 \\
\hline N.P. Cogen Inc. & Natural Gas & $\begin{array}{l}\text { Combined } \\
\text { Cycle/Topping Cycle }\end{array}$ & Cogen & Los Angeles & 24.7 \\
\hline San Gabriel Cogen & Natural Gas & $\begin{array}{l}\text { Combined } \\
\text { Cycle/Topping Cycle }\end{array}$ & Cogen & Los Angeles & 36 \\
\hline Glenarm & Natural Gas & Combustion Turbine & $\begin{array}{l}\text { Not } \\
\text { Cogen }\end{array}$ & Los Angeles & 60.8 \\
\hline Long Beach & Natural Gas & $\begin{array}{l}\text { Combustion Turbine, } \\
\text { Steam Turbine }\end{array}$ & $\begin{array}{l}\text { Not } \\
\text { Cogen }\end{array}$ & Los Angeles & 577 \\
\hline
\end{tabular}


a) Urban power plants (continued)

\begin{tabular}{|c|c|c|c|c|c|}
\hline PLANTNAME & PRIMARY FUEL & TECHNOLOGY & COGEN & COUNTY & $\begin{array}{l}\text { ONLINE } \\
\text { MW }\end{array}$ \\
\hline $\begin{array}{l}\text { St. John's Hospital } \\
\text { And Health Center }\end{array}$ & Natural Gas & $\begin{array}{l}\text { Combustion } \\
\text { Turbine/Topping Cycle }\end{array}$ & Cogen & Los Angeles & 1.08 \\
\hline $\begin{array}{l}\text { Pomona Power } \\
\text { Facility }\end{array}$ & Natural Gas & $\begin{array}{l}\text { Combustion } \\
\text { Turbine/Topping Cycle }\end{array}$ & Cogen & Los Angeles & 3.3 \\
\hline $\begin{array}{l}\text { Jefferson Smurfit } \\
\text { Corp. }\end{array}$ & Natural Gas & $\begin{array}{l}\text { Combustion } \\
\text { Turbine/Topping Cycle }\end{array}$ & Cogen & Los Angeles & 40 \\
\hline $\begin{array}{l}\text { Coldgen - Sunlaw } \\
\text { Cogen \#1 }\end{array}$ & Natural Gas & $\begin{array}{l}\text { Combustion } \\
\text { Turbine/Topping Cycle }\end{array}$ & Cogen & Los Angeles & 56 \\
\hline $\begin{array}{l}\text { Coldgen - Sunlaw } \\
\text { Cogen \#2 }\end{array}$ & Natural Gas & $\begin{array}{l}\text { Combustion } \\
\text { Turbine/Topping Cycle }\end{array}$ & Cogen & Los Angeles & 56 \\
\hline $\begin{array}{l}\text { Santa Monica Bay } \\
\text { Hotel }\end{array}$ & Natural Gas & $\begin{array}{l}\mathrm{Ct} / \text { Industrial Topping } \\
\text { Cycle }\end{array}$ & Cogen & Los Angeles & 0.95 \\
\hline $\begin{array}{l}\text { Vanguard - Electronic } \\
\text { Plating }\end{array}$ & Natural Gas & $\begin{array}{l}\text { Gas Fueled } \\
\text { Reciprocating Engine }\end{array}$ & Cogen & Los Angeles & 0.1 \\
\hline $\begin{array}{l}\text { Whittier Uhsd - La } \\
\text { Serna Hs }\end{array}$ & Natural Gas & $\begin{array}{l}\text { Gas Fueled } \\
\text { Reciprocating Engine }\end{array}$ & Cogen & Los Angeles & 0.1 \\
\hline The Forum \#1 & Natural Gas & $\begin{array}{l}\text { Gas Fueled } \\
\text { Reciprocating Engine }\end{array}$ & Cogen & Los Angeles & 0.115 \\
\hline The Episcopal Home & Natural Gas & $\begin{array}{l}\text { Gas Fueled } \\
\text { Reciprocating Engine }\end{array}$ & Cogen & Los Angeles & 0.2 \\
\hline $\begin{array}{l}\text { Southern California } \\
\text { Gas }\end{array}$ & Natural Gas & $\begin{array}{l}\text { Gas Fueled } \\
\text { Reciprocating Engine }\end{array}$ & Cogen & Los Angeles & 0.55 \\
\hline $\begin{array}{l}\text { Great Western } \\
\text { Malting Co. }\end{array}$ & Natural Gas & $\begin{array}{l}\text { Gas Fueled } \\
\text { Reciprocating Engine }\end{array}$ & Cogen & Los Angeles & 0.75 \\
\hline Biola University & Natural Gas & Gas Turbine & Cogen & Los Angeles & 1.2 \\
\hline Smurfit Pomona Mill & Natural Gas & Gas Turbine & Cogen & Los Angeles & 16.3 \\
\hline Pitchess Cogen & Natural Gas & Gas Turbine & Cogen & Los Angeles & 28.3 \\
\hline Norwalk Energy & Natural Gas & Gas Turbine & Cogen & Los Angeles & 30.75 \\
\hline UCLA Cogen & Natural Gas & Gas Turbine & Cogen & Los Angeles & 43 \\
\hline
\end{tabular}


a) Urban power plants (continued)

\begin{tabular}{|c|c|c|c|c|c|}
\hline PLANTNAME & PRIMARY FUEL & TECHNOLOGY & COGEN & COUNTY & $\begin{array}{l}\text { ONLINE } \\
\text { MW }\end{array}$ \\
\hline Los Angeles Refinery & Natural Gas & Gas Turbine & Cogen & Los Angeles & 68.5 \\
\hline Harbor Cogen & Natural Gas & Gas Turbine & Cogen & Los Angeles & 81.7 \\
\hline $\begin{array}{l}\text { Texaco Los Angeles } \\
\text { Refinery }\end{array}$ & Natural Gas & Gas Turbine & $\begin{array}{l}\text { Not } \\
\text { Cogen }\end{array}$ & Los Angeles & 60 \\
\hline $\begin{array}{l}\text { Anderson Litograph } \\
\text { Co. }\end{array}$ & Natural Gas & $\begin{array}{l}\text { Gas Turbine Combined } \\
\text { Cycle }\end{array}$ & Cogen & Los Angeles & 5 \\
\hline Civic Center Cogen & Natural Gas & $\begin{array}{l}\text { Gas Turbine, Steam } \\
\text { Turbine }\end{array}$ & Cogen & Los Angeles & 34.5 \\
\hline $\begin{array}{l}\text { O'brien California } \\
\text { Cogen }\end{array}$ & Natural Gas & $\begin{array}{l}\text { Gas Turbine, Steam } \\
\text { Turbine }\end{array}$ & Cogen & Los Angeles & 34.5 \\
\hline Carson Cogen Co. & Natural Gas & $\begin{array}{l}\text { Gas Turbine, Steam } \\
\text { Turbine }\end{array}$ & Cogen & Los Angeles & 49.5 \\
\hline Torrance Refinery & Natural Gas & $\begin{array}{l}\text { Gas Turbine, Steam } \\
\text { Turbine }\end{array}$ & Cogen & Los Angeles & 222.7 \\
\hline Watson Cogen & Natural Gas & $\begin{array}{l}\text { Gas Turbine, Steam } \\
\text { Turbine }\end{array}$ & Cogen & Los Angeles & 398 \\
\hline Aes Placerita & Natural Gas & $\begin{array}{l}\text { Gas Turbine/Steam } \\
\text { Turbine }\end{array}$ & Cogen & Los Angeles & 150 \\
\hline $\begin{array}{l}\text { Micro Utility - Safe } \\
\text { Planting }\end{array}$ & Natural Gas & $\begin{array}{l}\text { Gas-Fueled } \\
\text { Reciprocating Engine }\end{array}$ & Cogen & Los Angeles & 0.1 \\
\hline $\begin{array}{l}\text { Micro Utility - Foss } \\
\text { Planting }\end{array}$ & Natural Gas & $\begin{array}{l}\text { Gas-Fueled } \\
\text { Reciprocating Engine }\end{array}$ & Cogen & Los Angeles & 0.1 \\
\hline Xic - Erne Sanitarium & Natural Gas & $\begin{array}{l}\text { Gas-Fueled } \\
\text { Reciprocating Engine }\end{array}$ & Cogen & Los Angeles & 0.1 \\
\hline $\begin{array}{l}\text { Micro Utility - } \\
\text { Quaker }\end{array}$ & Natural Gas & $\begin{array}{l}\text { Gas-Fueled } \\
\text { Reciprocating Engine }\end{array}$ & Cogen & Los Angeles & 0.1 \\
\hline $\begin{array}{l}\text { Cal Poly University - } \\
\text { Pomona }\end{array}$ & Natural Gas & $\begin{array}{l}\text { Gas-Fueled } \\
\text { Reciprocating Engine }\end{array}$ & Cogen & Los Angeles & 0.115 \\
\hline $\begin{array}{l}\text { La Canada Usd - La } \\
\text { Canada School }\end{array}$ & Natural Gas & $\begin{array}{l}\text { Gas-Fueled } \\
\text { Reciprocating Engine }\end{array}$ & Cogen & Los Angeles & 0.12 \\
\hline
\end{tabular}


a) Urban power plants (continued)

\begin{tabular}{|c|c|c|c|c|c|}
\hline PLANTNAME & PRIMARY FUEL & TECHNOLOGY & COGEN & COUNTY & $\begin{array}{l}\text { ONLINE } \\
\text { MW }\end{array}$ \\
\hline $\begin{array}{l}\text { Mt. San Antonio } \\
\text { Gardens }\end{array}$ & Natural Gas & $\begin{array}{l}\text { Gas-Fueled } \\
\text { Reciprocating Engine }\end{array}$ & Cogen & Los Angeles & 0.12 \\
\hline $\begin{array}{l}\text { City Of Long Beach - } \\
\text { Belmont Plaza Pool }\end{array}$ & Natural Gas & $\begin{array}{l}\text { Gas-Fueled } \\
\text { Reciprocating Engine }\end{array}$ & Cogen & Los Angeles & 0.12 \\
\hline Bixby Knolls Towers & Natural Gas & $\begin{array}{l}\text { Gas-Fueled } \\
\text { Reciprocating Engine }\end{array}$ & Cogen & Los Angeles & 0.124 \\
\hline Cerritos College & Natural Gas & $\begin{array}{l}\text { Gas-Fueled } \\
\text { Reciprocating Engine }\end{array}$ & Cogen & Los Angeles & 0.15 \\
\hline $\begin{array}{l}\text { Csu Long Beach - } \\
\text { Dorm }\end{array}$ & Natural Gas & $\begin{array}{l}\text { Gas-Fueled } \\
\text { Reciprocating Engine }\end{array}$ & Cogen & Los Angeles & 0.15 \\
\hline $\begin{array}{l}\text { Csu Long Beach - } \\
\text { Pool }\end{array}$ & Natural Gas & $\begin{array}{l}\text { Gas-Fueled } \\
\text { Reciprocating Engine }\end{array}$ & Cogen & Los Angeles & 0.2 \\
\hline $\begin{array}{l}\text { Claremont Tennis } \\
\text { Club }\end{array}$ & Natural Gas & $\begin{array}{l}\text { Gas-Fueled } \\
\text { Reciprocating Engine }\end{array}$ & Cogen & Los Angeles & 0.2 \\
\hline Metal Surfaces & Natural Gas & $\begin{array}{l}\text { Gas-Fueled } \\
\text { Reciprocating Engine }\end{array}$ & Cogen & Los Angeles & 0.35 \\
\hline $\begin{array}{l}\text { Henry Mayo Newhall } \\
\text { Memorial Hospital }\end{array}$ & Natural Gas & $\begin{array}{l}\text { Gas-Fueled } \\
\text { Reciprocating Engine }\end{array}$ & Cogen & Los Angeles & 0.45 \\
\hline $\begin{array}{l}\text { Presbyterian } \\
\text { Intercommunity } \\
\text { Hospital }\end{array}$ & Natural Gas & $\begin{array}{l}\text { Gas-Fueled } \\
\text { Reciprocating Engine }\end{array}$ & Cogen & Los Angeles & 0.48 \\
\hline Petrominerals Corp. & Natural Gas & $\begin{array}{l}\text { Gas-Fueled } \\
\text { Reciprocating Engine }\end{array}$ & Cogen & Los Angeles & 0.5 \\
\hline \begin{tabular}{|l|} 
Pomona Valley \\
Community Hospital
\end{tabular} & Natural Gas & $\begin{array}{l}\text { Gas-Fueled } \\
\text { Reciprocating Engine }\end{array}$ & Cogen & Los Angeles & 0.8 \\
\hline Queen Mary & Natural Gas & $\begin{array}{l}\text { Gas-Fueled } \\
\text { Reciprocating Engine }\end{array}$ & Cogen & Los Angeles & 1 \\
\hline Paper Pak Products & Natural Gas & $\begin{array}{l}\text { Gas-Fueled } \\
\text { Reciprocating Engine }\end{array}$ & Cogen & Los Angeles & 1.4 \\
\hline Placerita Unit I & Natural Gas & I.C. Topping Cycle & Cogen & Los Angeles & 21.76 \\
\hline
\end{tabular}


a) Urban power plants (continued)

\begin{tabular}{|c|c|c|c|c|c|}
\hline PLANTNAME & PRIMARY FUEL & TECHNOLOGY & COGEN & COUNTY & $\begin{array}{l}\text { ONLINE } \\
\text { MW }\end{array}$ \\
\hline Placerita Unit Ii & Natural Gas & I.C. Topping Cycle & Cogen & Los Angeles & 21.76 \\
\hline $\begin{array}{l}\text { Los Angeles Cold } \\
\text { Storage }\end{array}$ & Natural Gas & Internal Combustion & Cogen & Los Angeles & 1.35 \\
\hline Vernon & Natural Gas & Internal Combustion & $\begin{array}{l}\text { Not } \\
\text { Cogen }\end{array}$ & Los Angeles & 30.6 \\
\hline Dex & Natural Gas & Natural Gas & Cogen & Los Angeles & 0.5 \\
\hline Bentley Mills & Natural Gas & Photovoltaic Engine & Cogen & Los Angeles & 0.8 \\
\hline $\begin{array}{l}\text { Rhone-Poulenc - } \\
\text { Dominguez Plant }\end{array}$ & Natural Gas & $\begin{array}{l}\text { Process Steam } \\
\text { Plant/Bottoming Cycle }\end{array}$ & Cogen & Los Angeles & 4.9 \\
\hline Lake One & Natural Gas & Reclaimed Water & $\begin{array}{l}\text { Not } \\
\text { Cogen }\end{array}$ & Los Angeles & 47 \\
\hline Grayson & Natural Gas & $\begin{array}{l}\text { Steam \& Combustion } \\
\text { Turbine, Comb. Cycle }\end{array}$ & $\begin{array}{l}\text { Not } \\
\text { Cogen }\end{array}$ & Los Angeles & 272.5 \\
\hline $\begin{array}{l}\text { Arco Petroleum } \\
\text { Products Co. }\end{array}$ & Natural Gas & Steam Turbine & Cogen & Los Angeles & 13.5 \\
\hline Broadway & Natural Gas & Steam Turbine & $\begin{array}{l}\text { Not } \\
\text { Cogen }\end{array}$ & Los Angeles & 162 \\
\hline El Segundo & Natural Gas & Steam Turbine & $\begin{array}{l}\text { Not } \\
\text { Cogen }\end{array}$ & Los Angeles & 708 \\
\hline Magnolia & Natural Gas & $\begin{array}{l}\text { Steam Turbine, } \\
\text { Combined Cycle }\end{array}$ & $\begin{array}{l}\text { Not } \\
\text { Cogen }\end{array}$ & Los Angeles & 81.7 \\
\hline $\begin{array}{l}\text { California Institute } \\
\text { Of Technology }\end{array}$ & Natural Gas & $\begin{array}{l}\text { Steam Turbine, Gas } \\
\text { Turbine }\end{array}$ & Cogen & Los Angeles & 5.3 \\
\hline Olive & Natural Gas & $\begin{array}{l}\text { Steam Turbine, Gas } \\
\text { Turbine }\end{array}$ & $\begin{array}{l}\text { Not } \\
\text { Cogen }\end{array}$ & Los Angeles & 152.5 \\
\hline Valley & Natural Gas & $\begin{array}{l}\text { Steam Turbine, Natural } \\
\text { Gas }\end{array}$ & $\begin{array}{l}\text { Not } \\
\text { Cogen }\end{array}$ & Los Angeles & 517 \\
\hline Scattergood & Natural Gas & $\begin{array}{l}\text { Steam Turbine, Natural } \\
\text { Gas }\end{array}$ & $\begin{array}{l}\text { Not } \\
\text { Cogen }\end{array}$ & Los Angeles & 803 \\
\hline Haynes & Natural Gas & Steam Turbine, Natural & Not & Los Angeles & 1570 \\
\hline
\end{tabular}


a) Urban power plants (continued)

\begin{tabular}{|c|c|c|c|c|c|}
\hline PLANTNAME & PRIMARY FUEL & TECHNOLOGY & COGEN & COUNTY & $\begin{array}{l}\text { ONLINE } \\
\text { MW }\end{array}$ \\
\hline & & Gas & Cogen & & \\
\hline $\begin{array}{l}\text { St. Luke Medical } \\
\text { Center }\end{array}$ & Natural Gas & & Cogen & Los Angeles & 1 \\
\hline Techni-Cast Corp. & Natural Gas & & Cogen & Los Angeles & 1.063 \\
\hline Cbs Studios & Natural Gas & & Cogen & Los Angeles & 1.4 \\
\hline Ucla Cogen & Natural Gas & & Cogen & Los Angeles & 43 \\
\hline $\begin{array}{l}\text { Redondo Beach } \\
\text { Generating Stat }\end{array}$ & Natural Gas & & $\begin{array}{l}\text { Not } \\
\text { Cogen }\end{array}$ & Los Angeles & 1317 \\
\hline $\begin{array}{l}\text { Southern California } \\
\text { Gas - Scaqmd }\end{array}$ & Oil/Gas & $\begin{array}{l}\text { Fuel Cell/Wasteheat } \\
\text { Recovery }\end{array}$ & Cogen & Los Angeles & 0.2 \\
\hline Wilmington & Waste Heat & Steam Turbine & $\begin{array}{l}\text { Not } \\
\text { Cogen }\end{array}$ & Los Angeles & 31.9 \\
\hline Total Energy Facility & Digester Gas & $\begin{array}{l}\text { Gas Turbine Combined } \\
\text { Cycle }\end{array}$ & Cogen & Los Angeles & 25 \\
\hline $\begin{array}{l}\text { Puente Hills } \\
\text { Recovery }\end{array}$ & Landfill Gas & Gas Turbine & $\begin{array}{l}\text { Not } \\
\text { Cogen }\end{array}$ & Los Angeles & 7.8 \\
\hline $\begin{array}{l}\text { Palos Verdes Gas To } \\
\text { Energy Facility }\end{array}$ & Landfill Gas & Reciprocating Engine & $\begin{array}{l}\text { Not } \\
\text { Cogen }\end{array}$ & Los Angeles & 13 \\
\hline $\begin{array}{l}\text { Spadra Landfill Gas } \\
\text { To Energy }\end{array}$ & Landfill Gas & Steam Turbine & $\begin{array}{l}\text { Not } \\
\text { Cogen }\end{array}$ & Los Angeles & 9.9 \\
\hline Mm West Corvina Llc & Msw & $\begin{array}{l}\text { Landfill Gas Recovery, } \\
\text { Steam Turbine }\end{array}$ & $\begin{array}{l}\text { Not } \\
\text { Cogen }\end{array}$ & Los Angeles & 3.25 \\
\hline $\begin{array}{l}\text { Southeast Resource } \\
\text { Recovery }\end{array}$ & Msw & Municipal Solid Waste & $\mid \begin{array}{l}\text { Not } \\
\text { Cogen }\end{array}$ & Los Angeles & 34.6 \\
\hline Penrose & Msw & Reciprocating Engine & $\begin{array}{l}\text { Not } \\
\text { Cogen }\end{array}$ & Los Angeles & 9.25 \\
\hline Toyon & Msw & Reciprocating Engine & $\begin{array}{l}\text { Not } \\
\text { Cogen }\end{array}$ & Los Angeles & 9.3 \\
\hline $\begin{array}{l}\text { Mm Lopez Energy } \\
\text { Llc }\end{array}$ & Msw & Reciprocating Engine & $\begin{array}{l}\text { Not } \\
\text { Cogen }\end{array}$ & Los Angeles & 6.6 \\
\hline
\end{tabular}


a) Urban power plants (continued)

\begin{tabular}{|c|c|c|c|c|c|}
\hline PLANTNAME & PRIMARY FUEL & TECHNOLOGY & COGEN & COUNTY & $\begin{array}{l}\text { ONLINE } \\
\text { MW }\end{array}$ \\
\hline $\begin{array}{l}\text { Commerce Refuse To } \\
\text { Energy }\end{array}$ & Msw & Steam Turbine & $\begin{array}{l}\text { Not } \\
\text { Cogen }\end{array}$ & Los Angeles & 11.5 \\
\hline $\begin{array}{l}\text { San Joaquin Power } \\
\text { Co. }\end{array}$ & Natural Gas & & Cogen & Merced & 10.75 \\
\hline J.R. Woods Inc. & Msw & Landfill Gas & Cogen & Merced & 1.05 \\
\hline $\begin{array}{l}\text { Calpine King City } \\
\text { Cogen }\end{array}$ & Natural Gas & Combined Cycle & Cogen & Monterey & 130 \\
\hline $\begin{array}{l}\text { Sargent Canyon } \\
\text { Cogen }\end{array}$ & Natural Gas & Gas Turbine & Cogen & Monterey & 38 \\
\hline Salinas River Cogen & Natural Gas & Gas Turbine & Cogen & Monterey & 49.6 \\
\hline Moss Landing & Natural Gas & Steam Turbine & $\begin{array}{l}\text { Not } \\
\text { Cogen }\end{array}$ & Monterey & 2545 \\
\hline Asilomar & Natural Gas & & Cogen & Monterey & 0.55 \\
\hline Soledad State Prison & Natural Gas & & Cogen & Monterey & 2.2 \\
\hline Monterey Power Co. & Natural Gas & & Cogen & Monterey & 6 \\
\hline $\begin{array}{l}\text { Calpine King Energy } \\
\text { Center }\end{array}$ & Natural Gas & Brown Field & $\mid \begin{array}{l}\text { Not } \\
\text { Cogen }\end{array}$ & Monterey & 50 \\
\hline $\begin{array}{l}\text { Monterey Regional } \\
\text { Water Pollution } \\
\text { Control Cogen }\end{array}$ & Msw & Digester Gas & Cogen & Monterey & 1.74 \\
\hline Salinas & Msw & Internal Combustion & $\begin{array}{l}\text { Not } \\
\text { Cogen }\end{array}$ & Monterey & 1.4 \\
\hline Marina Landfill Gas & Msw & Landfill Gas & $\begin{array}{l}\text { Not } \\
\text { Cogen }\end{array}$ & Monterey & 5.4 \\
\hline Napa State Hospital & Natural Gas & Gas Turbine & Cogen & Napa & 1.6 \\
\hline Yountville Cogen & Natural Gas & Gas Turbine & Cogen & Napa & 3 \\
\hline $\begin{array}{l}\text { American Canyon } \\
\text { Power Plant }\end{array}$ & Landfill Gas & Reciprocating Engine & $\begin{array}{l}\text { Not } \\
\text { Cogen }\end{array}$ & Napa & 1.76 \\
\hline Huntington Beach & Distillate Oil & $\begin{array}{l}\text { Steam Turbine, Gas } \\
\text { Turbine }\end{array}$ & $\begin{array}{l}\text { Not } \\
\text { Cogen }\end{array}$ & Orange & 880 \\
\hline
\end{tabular}


a) Urban power plants (continued)

\begin{tabular}{|c|c|c|c|c|c|}
\hline PLANTNAME & PRIMARY FUEL & TECHNOLOGY & COGEN & COUNTY & $\begin{array}{l}\text { ONLINE } \\
\text { MW }\end{array}$ \\
\hline $\begin{array}{l}\text { Chiquita Water } \\
\text { Reclamation }\end{array}$ & Methane & Recipocating Engine & $\begin{array}{l}\text { Not } \\
\text { Cogen }\end{array}$ & Orange & 0.27 \\
\hline Unocal Research & Natural Gas & $\begin{array}{l}\text { Combustion } \\
\text { Turbine/Topping Cycle }\end{array}$ & Cogen & Orange & 3.623 \\
\hline $\begin{array}{l}\text { Southern California } \\
\text { Gas - Hyatt Regency }\end{array}$ & Natural Gas & $\begin{array}{l}\text { Fuel Cell/Wasteheat } \\
\text { Recovery }\end{array}$ & Cogen & Orange & 0.2 \\
\hline Turbine Tech & Natural Gas & $\begin{array}{l}\text { Gas Fueled } \\
\text { Reciprocating Engine }\end{array}$ & Cogen & Orange & 0.15 \\
\hline American Mcgaw \#2 & Natural Gas & Gas-Turbine & Cogen & Orange & 6.1 \\
\hline $\begin{array}{l}\text { Anaheim Gas } \\
\text { Turbine }\end{array}$ & Natural Gas & $\begin{array}{l}\text { Gas Turbine, Natural } \\
\text { Gas }\end{array}$ & $\begin{array}{l}\text { Not } \\
\text { Cogen }\end{array}$ & Orange & 45.55 \\
\hline Pca Metal Finishing & Natural Gas & $\begin{array}{l}\text { Gas-Fueled } \\
\text { Reciprocating Engine }\end{array}$ & Cogen & Orange & 0.1 \\
\hline $\begin{array}{l}\text { American } \\
\text { Cornerstone - } \\
\text { Holiday Inn }\end{array}$ & Natural Gas & $\begin{array}{l}\text { Gas-Fueled } \\
\text { Reciprocating Engine }\end{array}$ & Cogen & Orange & 0.15 \\
\hline All Metals Processing & Natural Gas & $\begin{array}{l}\text { Gas-Fueled } \\
\text { Reciprocating Engine }\end{array}$ & Cogen & Orange & 0.175 \\
\hline Royalty Carpet Mills & Natural Gas & $\begin{array}{l}\text { Gas-Fueled } \\
\text { Reciprocating Engine }\end{array}$ & Cogen & Orange & 0.425 \\
\hline Red Lion Inn & Natural Gas & $\begin{array}{l}\text { Gas-Fueled } \\
\text { Reciprocating Engine }\end{array}$ & Cogen & Orange & 0.46 \\
\hline $\begin{array}{l}\text { Orange County } \\
\text { Sanitation District } \\
\text { Plant } 1\end{array}$ & Natural Gas & $\begin{array}{l}\text { Gas-Fueled } \\
\text { reciprocating Engine }\end{array}$ & Cogen & Orange & 4.5 \\
\hline American Mcgaw & Natural Gas & $\begin{array}{l}\text { Steam Turbine \& Gas } \\
\text { Turbine }\end{array}$ & Cogen & Orange & 8.6 \\
\hline $\begin{array}{l}\text { Aliso Water } \\
\text { Management Agency }\end{array}$ & Digester Gas & Digester Gas/Municipal & $\begin{array}{l}\text { Not } \\
\text { Cogen }\end{array}$ & Orange & 1.2 \\
\hline Plant No. 2 & Digester Gas & Digester Gas/Other & $\begin{array}{l}\text { Not } \\
\text { Cogen }\end{array}$ & Orange & 18 \\
\hline
\end{tabular}


a) Urban power plants (continued)

\begin{tabular}{|c|c|c|c|c|c|}
\hline PLANTNAME & PRIMARY FUEL & TECHNOLOGY & COGEN & COUNTY & $\begin{array}{l}\text { ONLINE } \\
\text { MW }\end{array}$ \\
\hline $\begin{array}{l}\text { Mm Prima Deschecha } \\
\text { Energy Lic }\end{array}$ & Landfill Gas & Reciprocating Engine & $\begin{array}{l}\text { Not } \\
\text { Cogen }\end{array}$ & Orange & 6.1 \\
\hline Coyote Canyon & Landfill Gas & Steam Turbine & $\begin{array}{l}\text { Not } \\
\text { Cogen }\end{array}$ & Orange & 20 \\
\hline $\begin{array}{l}\text { Brea Power Partners } \\
\text { Lp }\end{array}$ & Msw & Reciprocating Engine & $\begin{array}{l}\text { Not } \\
\text { Cogen }\end{array}$ & Orange & 5.4 \\
\hline Kings Beach & Diesel & Internal Combustion & $\begin{array}{l}\text { Not } \\
\text { Cogen }\end{array}$ & Placer & 16.2 \\
\hline Roseville & Natural Gas & Combustion Turbine & $\begin{array}{l}\text { Not } \\
\text { Cogen }\end{array}$ & Placer & 53.75 \\
\hline Spi- Lincoln & Woodwaste & Steam Turbine & Cogen & Placer & 13 \\
\hline Rio Bravo Rocklin & Woodwaste & Steam Turbine & $\begin{array}{l}\text { Not } \\
\text { Cogen }\end{array}$ & Placer & 24.4 \\
\hline Coachella & Natural Gas & $\begin{array}{l}\text { Combustion Turbine, } \\
\text { Natural Gas }\end{array}$ & $\begin{array}{l}\text { Not } \\
\text { Cogen }\end{array}$ & Riverside & 80 \\
\hline Municipal Cogen & Natural Gas & Gas Turbine & Cogen & Riverside & 1.3 \\
\hline Corona Cogen & Natural Gas & Gas Turbine & Cogen & Riverside & 47 \\
\hline $\begin{array}{l}\text { Springs Generation } \\
\text { Project }\end{array}$ & Natural Gas & Gas Turbine & $\begin{array}{l}\text { Not } \\
\text { Cogen }\end{array}$ & Riverside & 40 \\
\hline $\begin{array}{l}\text { Eua/Frcii - Monterey } \\
\text { Country Club }\end{array}$ & Natural Gas & $\begin{array}{l}\text { Gas-Fueled } \\
\text { Reciprocating Engine }\end{array}$ & Cogen & Riverside & 0.115 \\
\hline $\begin{array}{l}\text { Eua/Frcii - Palm } \\
\text { Valley Country Club }\end{array}$ & Natural Gas & $\begin{array}{l}\text { Gas-Fueled } \\
\text { Reciprocating Engine }\end{array}$ & Cogen & Riverside & 0.41 \\
\hline Ces Energy Alberhill & Natural Gas & $\begin{array}{l}\text { Gas-Fueled } \\
\text { Reciprocating Engine }\end{array}$ & Cogen & Riverside & 0.56 \\
\hline $\begin{array}{l}\text { Ces Energy Corona - } \\
\text { Pacific Clay }\end{array}$ & Natural Gas & $\begin{array}{l}\text { Gas-Fueled } \\
\text { Reciprocating Engine }\end{array}$ & Cogen & Riverside & 0.6 \\
\hline $\begin{array}{l}\text { Eua/Frcii - Vintage } \\
\text { Country Club }\end{array}$ & Natural Gas & $\begin{array}{l}\text { Gas-Fueled } \\
\text { Reciprocating Engine }\end{array}$ & Cogen & Riverside & 0.6 \\
\hline $\begin{array}{l}\text { City Of Palm Springs } \\
\text { - Sunrise Plaza }\end{array}$ & Natural Gas & $\begin{array}{l}\text { Gas-Fueled } \\
\text { Reciprocating Engine }\end{array}$ & Cogen & Riverside & 0.641 \\
\hline
\end{tabular}


a) Urban power plants (continued)

\begin{tabular}{|c|c|c|c|c|c|}
\hline PLANTNAME & PRIMARY FUEL & TECHNOLOGY & COGEN & COUNTY & $\begin{array}{l}\text { ONLINE } \\
\text { MW }\end{array}$ \\
\hline Wildflower - Indigo & Natural Gas & Green Field & $\begin{array}{l}\text { Not } \\
\text { Cogen }\end{array}$ & Riverside & 135 \\
\hline Mecca Plant & $\begin{array}{l}\text { Ag. \& } \\
\text { Woodwaste }\end{array}$ & Steam Turbine, Cfb & $\begin{array}{l}\text { Not } \\
\text { Cogen }\end{array}$ & Riverside & 47 \\
\hline Corona Landfill & MSW & Landfill Gas Recovery & $\begin{array}{l}\text { Not } \\
\text { Cogen }\end{array}$ & Riverside & 0.6 \\
\hline Carson Cogen & Natural Gas & $\begin{array}{l}\text { Combustion Turbine } \\
\text { With Waste Heat }\end{array}$ & Cogen & Sacramento & 97 \\
\hline Spac & Natural Gas & $\begin{array}{l}\text { Combustion Turbine } \\
\text { With Waste Heat }\end{array}$ & Cogen & Sacramento & 146 \\
\hline $\begin{array}{l}\text { Proctor \& Gamble - } \\
\text { Smud }\end{array}$ & Natural Gas & $\begin{array}{l}\text { Combustion Turbine } \\
\text { With Waste Heat }\end{array}$ & Cogen & Sacramento & 193.4 \\
\hline Mcclellan & Natural Gas & $\begin{array}{l}\text { Combustion Turbine, } \\
\text { Natural Gas }\end{array}$ & $\begin{array}{l}\text { Not } \\
\text { Cogen }\end{array}$ & Sacramento & 49 \\
\hline $\begin{array}{l}\text { Kiefer Landfill Gas } \\
\text { To Energy Facility }\end{array}$ & Landfill Gas & Methane Gas & & Sacramento & 8.3 \\
\hline Century & Natural Gas & & $\begin{array}{l}\text { Not } \\
\text { Cogen }\end{array}$ & San Bernadino & 40 \\
\hline $\begin{array}{l}\text { Txi Riverside Cement } \\
\text { Power House }\end{array}$ & Coal & $\begin{array}{l}\text { Coal Fired Bottoming } \\
\text { Cycle }\end{array}$ & Cogen & San Bernardino & 17 \\
\hline Argus Cogen Plant & Coal & $\begin{array}{l}\text { Coal-Fired Topping } \\
\text { Cycle }\end{array}$ & Cogen & San Bernardino & 55 \\
\hline Ace Xeration & Coal & $\begin{array}{l}\text { Coal-Fired Topping } \\
\text { Cycle }\end{array}$ & $\begin{array}{l}\text { Not } \\
\text { Cogen }\end{array}$ & San Bernardino & 108 \\
\hline Etiwanda & Distillate Oil & $\begin{array}{l}\text { Steam Turbine, Gas } \\
\text { Turbine }\end{array}$ & $\begin{array}{l}\text { Not } \\
\text { Cogen }\end{array}$ & San Bernardino & 770 \\
\hline $\begin{array}{l}\text { High Desert Power } \\
\text { Plant Project }\end{array}$ & Natural Gas & Combined Cycle & $\begin{array}{l}\text { Not } \\
\text { Cogen }\end{array}$ & San Bernardino & 750 \\
\hline Westend & Natural Gas & $\begin{array}{l}\text { Combustion } \\
\text { Turbine/Topping Cycle }\end{array}$ & Cogen & San Bernardino & 15 \\
\hline
\end{tabular}


a) Urban power plants (continued)

\begin{tabular}{|c|c|c|c|c|c|}
\hline PLANTNAME & PRIMARY FUEL & TECHNOLOGY & COGEN & COUNTY & $\begin{array}{l}\text { ONLINE } \\
\text { MW }\end{array}$ \\
\hline $\begin{array}{l}\text { Victor Valley } \\
\text { Community Hospital }\end{array}$ & Natural Gas & $\begin{array}{l}\text { Gas Fueled } \\
\text { Reciprocating Engine }\end{array}$ & Cogen & San Bernardino & 0.135 \\
\hline $\begin{array}{l}\text { Transamerican } \\
\text { Plastics }\end{array}$ & Natural Gas & $\begin{array}{l}\text { Gas Fueled } \\
\text { Reciprocating Engine }\end{array}$ & Cogen & San Bernardino & 0.34 \\
\hline Indeck Ontario & Natural Gas & Gas Turbine & Cogen & San Bernardino & 12 \\
\hline Ontario Mill & Natural Gas & Gas Turbine & Cogen & San Bernardino & 34 \\
\hline $\begin{array}{l}\text { Loma Linda } \\
\text { University }\end{array}$ & Natural Gas & $\begin{array}{l}\text { Gas Turbine, Steam } \\
\text { Turbine, Internal Com }\end{array}$ & Cogen & San Bernardino & 13.4 \\
\hline Rialto Usd & Natural Gas & $\begin{array}{l}\text { Gas-Fueled } \\
\text { Reciprocating Engine }\end{array}$ & Cogen & San Bernardino & 0.1 \\
\hline $\begin{array}{l}\text { Rimrock Village } \\
\text { Partership }\end{array}$ & Natural Gas & $\begin{array}{l}\text { Gas-Fueled } \\
\text { Reciprocating Engine }\end{array}$ & Cogen & San Bernardino & 0.12 \\
\hline $\begin{array}{l}\text { Micro Utility - Lake } \\
\text { Arrowhead Hilton }\end{array}$ & Natural Gas & $\begin{array}{l}\text { Gas-Fueled } \\
\text { Reciprocating Engine }\end{array}$ & Cogen & San Bernardino & 0.28 \\
\hline San Antonio Hospital & Natural Gas & $\begin{array}{l}\text { Gas-Fueled } \\
\text { Reciprocating Engine }\end{array}$ & Cogen & San Bernardino & 1.8 \\
\hline Mcanally Egg Ranch & Natural Gas & Natural Gas & Cogen & San Bernardino & 0.12 \\
\hline $\begin{array}{l}\text { Riverside Canal } \\
\text { Power }\end{array}$ & Natural Gas & Steam Turbine & $\begin{array}{l}\text { Not } \\
\text { Cogen }\end{array}$ & San Bernardino & 160 \\
\hline $\begin{array}{l}\text { Mountainview Power } \\
\text { Co. - San Bernardino }\end{array}$ & Natural Gas & Stream Turbine & $\begin{array}{l}\text { Not } \\
\text { Cogen }\end{array}$ & San Bernardino & 126 \\
\hline Coolwater & Natural Gas & $\begin{array}{l}\text { Steam Turbine, } \\
\text { Combined Cycle }\end{array}$ & $\begin{array}{l}\text { Not } \\
\text { Cogen }\end{array}$ & San Bernardino & 726.3 \\
\hline Chino Nug & $\begin{array}{l}\text { Natural Gas, } \\
\text { Distill }\end{array}$ & $\begin{array}{l}\text { Combined } \\
\text { Cycle/Topping Cycle }\end{array}$ & Cogen & San Bernardino & 27.6 \\
\hline Drews & Natural Gas & Brown Field & $\begin{array}{l}\text { Not } \\
\text { Cogen }\end{array}$ & San Bernardino & 40 \\
\hline Division & Distillate Oil & Gas Turbine & $\begin{array}{l}\text { Not } \\
\text { Cogen }\end{array}$ & San Diego & 13 \\
\hline El Cajon & Distillate Oil & Gas Turbine & Not & San Diego & 13 \\
\hline
\end{tabular}


a) Urban power plants (continued)

\begin{tabular}{|c|c|c|c|c|c|}
\hline PLANTNAME & PRIMARY FUEL & TECHNOLOGY & COGEN & COUNTY & $\begin{array}{l}\text { ONLINE } \\
\text { MW }\end{array}$ \\
\hline & & & Cogen & & \\
\hline Chula Vista Cogen & Natural Gas & Combined Cycle & Cogen & San Diego & 9 \\
\hline Miramar & Natural Gas & Combustion Turbine & $\begin{array}{l}\text { Not } \\
\text { Cogen }\end{array}$ & San Diego & 33 \\
\hline Ntc Central & Natural Gas & $\begin{array}{l}\text { Combustion Turbine } \\
\text { With Waste Heat }\end{array}$ & Cogen & San Diego & 16 \\
\hline Naval Station & Natural Gas & $\begin{array}{l}\text { Combustion Turbine } \\
\text { With Waste Heat }\end{array}$ & Cogen & San Diego & 26 \\
\hline Va Hospital & Natural Gas & Gas Trubine & Cogen & San Diego & 0.85 \\
\hline Hotel Del Coronado & Natural Gas & Gas Turbine & Cogen & San Diego & 0.8 \\
\hline Palomar Hospital & Natural Gas & Gas Turbine & Cogen & San Diego & 1.3 \\
\hline Children's Hospital & Natural Gas & Gas Turbine & Cogen & San Diego & 1.5 \\
\hline Grossmont Hospital & Natural Gas & Gas Turbine & Cogen & San Diego & 1.6 \\
\hline $\begin{array}{l}\text { Medical Center } \\
\text { Hospital }\end{array}$ & Natural Gas & Gas Turbine & Cogen & San Diego & 2.4 \\
\hline Qualcomm & Natural Gas & Gas Turbine & Cogen & San Diego & 2.4 \\
\hline Sdsu Main & Natural Gas & Gas Turbine & Cogen & San Diego & 3 \\
\hline $\begin{array}{l}\text { Union-Tribune } \\
\text { Publishing Co. }\end{array}$ & Natural Gas & Gas Turbine & Cogen & San Diego & 3 \\
\hline $\begin{array}{l}\text { R.J. Donovan } \\
\text { Correctional Facility }\end{array}$ & Natural Gas & Gas Turbine & Cogen & San Diego & 3.13 \\
\hline Sea World & Natural Gas & Gas Turbine & Cogen & San Diego & 3.5 \\
\hline Nutra Sweet Kelco. & Natural Gas & Gas Turbine & Cogen & San Diego & 24 \\
\hline $\begin{array}{l}\text { North Island Energy } \\
\text { Facility }\end{array}$ & Natural Gas & Gas Turbine & Cogen & San Diego & 38.55 \\
\hline Goal Line & Natural Gas & Gas Turbine & Cogen & San Diego & 51.4 \\
\hline Solar Turbines Inc. & Natural Gas & Gas Turbine & $\begin{array}{l}\text { Not } \\
\text { Cogen }\end{array}$ & San Diego & 8.9 \\
\hline
\end{tabular}


a) Urban power plants (continued)

\begin{tabular}{|c|c|c|c|c|c|}
\hline PLANTNAME & PRIMARY FUEL & TECHNOLOGY & COGEN & COUNTY & $\begin{array}{c}\text { ONLINE } \\
\text { MW }\end{array}$ \\
\hline North Island & Natural Gas & Gas Turbine & $\begin{array}{l}\text { Not } \\
\text { Cogen }\end{array}$ & San Diego & 34 \\
\hline Kearny & Natural Gas & Gas Turbine & $\begin{array}{l}\text { Not } \\
\text { Cogen }\end{array}$ & San Diego & 207 \\
\hline $\begin{array}{l}\text { Naval Station/ } \\
\text { Navaltraining Center }\end{array}$ & Natural Gas & $\begin{array}{l}\text { Gas Turbine, Steam } \\
\text { Turbine }\end{array}$ & Cogen & San Diego & 49.9 \\
\hline Trw & Natural Gas & $\begin{array}{l}\text { Gas Turbine/Internal } \\
\text { Combustion }\end{array}$ & Cogen & San Diego & 1.3 \\
\hline $\begin{array}{l}\text { Bf Goodrich Xeration } \\
\text { Plant }\end{array}$ & Natural Gas & Internal Combustion & Cogen & San Diego & 9.495 \\
\hline El Conquistador & Natural Gas & Reciprocating Engine & Cogen & San Diego & 0.1 \\
\hline The Wave & Natural Gas & Reciprocating Engine & Cogen & San Diego & 0.12 \\
\hline $\begin{array}{l}\text { Grossmont } \\
\text { Community College }\end{array}$ & Natural Gas & Reciprocating Engine & Cogen & San Diego & 0.2 \\
\hline $\begin{array}{l}939 \text { Coast } \\
\text { Management }\end{array}$ & Natural Gas & Reciprocating Engine & Cogen & San Diego & 0.23 \\
\hline $\begin{array}{l}\text { Alliant Food Service } \\
\text { Inc. }\end{array}$ & Natural Gas & Reciprocating Engine & Cogen & San Diego & 0.29 \\
\hline Pomerado Hospital & Natural Gas & Reciprocating Engine & Cogen & San Diego & 0.35 \\
\hline Le Meridien Hotel I & Natural Gas & Reciprocating Engine & Cogen & San Diego & 0.6 \\
\hline Hunter Industries & Natural Gas & Reciprocating Engine & Cogen & San Diego & 0.69 \\
\hline Mercy Hospital Ii & Natural Gas & Reciprocating Engine & Cogen & San Diego & 0.8 \\
\hline $\begin{array}{l}\text { Mariott Hotel \& } \\
\text { Marina Ii - South }\end{array}$ & Natural Gas & Reciprocating Engine & Cogen & San Diego & 0.8 \\
\hline $\begin{array}{l}\text { Mariott Hotel \& } \\
\text { Marina I - North }\end{array}$ & Natural Gas & Reciprocating Engine & Cogen & San Diego & 0.8 \\
\hline Southwest Marine & Natural Gas & Reciprocating Engine & Cogen & San Diego & 1.3 \\
\hline Salk Institute & Natural Gas & Reciprocating Engine & Cogen & San Diego & 1.3 \\
\hline
\end{tabular}


a) Urban power plants (continued)

\begin{tabular}{|c|c|c|c|c|c|}
\hline PLANTNAME & PRIMARY FUEL & TECHNOLOGY & COGEN & COUNTY & $\begin{array}{l}\text { ONLINE } \\
\text { MW }\end{array}$ \\
\hline $\begin{array}{l}\text { Encina Water } \\
\text { Pollution Control }\end{array}$ & Natural Gas & Reciprocating Engine & Cogen & San Diego & 1.425 \\
\hline Ucsd & Natural Gas & Reciprocating Engine & Cogen & San Diego & 1.5 \\
\hline $\begin{array}{l}\text { San Diego Power \& } \\
\text { Cooling Co. }\end{array}$ & Natural Gas & Reciprocating Engine & Cogen & San Diego & 1.6 \\
\hline $\begin{array}{l}\text { Navy Reg. Data } \\
\text { Automation Center }\end{array}$ & Natural Gas & Reciprocating Engine & Cogen & San Diego & 2.6 \\
\hline Kyoceraproject & Natural Gas & Reciprocating Engine & Cogen & San Diego & 3.2 \\
\hline $\begin{array}{l}\text { South Bay Regional } \\
\text { Center }\end{array}$ & Natural Gas & Steam Turbne & Cogen & San Diego & 0.6 \\
\hline South Bay & Natural Gas & $\begin{array}{l}\text { Steam Turbine, Gas } \\
\text { Turbine }\end{array}$ & $\begin{array}{l}\text { Not } \\
\text { Cogen }\end{array}$ & San Diego & 706 \\
\hline Encina & Natural Gas & $\begin{array}{l}\text { Steam Turbines \& Gas } \\
\text { Turbine }\end{array}$ & $\begin{array}{l}\text { Not } \\
\text { Cogen }\end{array}$ & San Diego & 971 \\
\hline $\begin{array}{l}\text { Csc Western Center } \\
\text { Cogen }\end{array}$ & Natural Gas & Turbine & Cogen & San Diego & 3.5 \\
\hline $\begin{array}{l}\text { Holiday Inn } \\
\text { Embarcadero }\end{array}$ & Natural Gas & & Cogen & San Diego & 0.297 \\
\hline Pacific Bell & Natural Gas & & $\begin{array}{l}\text { Not } \\
\text { Cogen }\end{array}$ & San Diego & 6.42 \\
\hline $\begin{array}{l}\text { Calpeak Border, Llc } \\
\text { Phase I }\end{array}$ & Natural Gas & & $\begin{array}{l}\text { Not } \\
\text { Cogen }\end{array}$ & San Diego & 49.5 \\
\hline Calpeak Escondido & Natural Gas & & $\begin{array}{l}\text { Not } \\
\text { Cogen }\end{array}$ & San Diego & 49.5 \\
\hline $\begin{array}{l}\text { Calpeak Power E1 } \\
\text { Cajon, Llc }\end{array}$ & Natural Gas & & & San Diego & 48.68 \\
\hline $\begin{array}{l}\text { Ntc/Mcrd Energy } \\
\text { Facility }\end{array}$ & $\begin{array}{l}\text { Steam \& Natural } \\
\text { Gas }\end{array}$ & Combined Cycle & Cogen & San Diego & 25.6 \\
\hline Wildflower -Larkspur & Natural Gas & Green Field & $\begin{array}{l}\text { Not } \\
\text { Cogen }\end{array}$ & San Diego & 90 \\
\hline Gas Utilization & Digester Gas & Internal Combustion & Not & San Diego & 6.8 \\
\hline
\end{tabular}


a) Urban power plants (continued)

\begin{tabular}{|c|c|c|c|c|c|}
\hline PLANTNAME & PRIMARY FUEL & TECHNOLOGY & COGEN & COUNTY & $\begin{array}{l}\text { ONLINE } \\
\text { MW }\end{array}$ \\
\hline Facility & & & Cogen & & \\
\hline San Marcos & Landfill Gas & Gas Turbine & $\begin{array}{l}\text { Not } \\
\text { Cogen }\end{array}$ & San Diego & 1.8 \\
\hline Sycamore San Diego & Landfill Gas & Gas Turbine & $\begin{array}{l}\text { Not } \\
\text { Cogen }\end{array}$ & San Diego & 1.8 \\
\hline $\begin{array}{l}\text { Mm San Diego Lic - } \\
\text { Miramar }\end{array}$ & Landfill Gas & Internal Combustion & $\begin{array}{l}\text { Not } \\
\text { Cogen }\end{array}$ & San Diego & 6.5 \\
\hline $\begin{array}{l}\text { Mm San Diego Llc - } \\
\text { North City }\end{array}$ & Landfill Gas & Landfill Gas & $\begin{array}{l}\text { Not } \\
\text { Cogen }\end{array}$ & San Diego & 3.8 \\
\hline Otay & Landfill Gas & Reciprocating Engine & $\begin{array}{l}\text { Not } \\
\text { Cogen }\end{array}$ & San Diego & 3.87 \\
\hline $\begin{array}{l}\text { Southeast Digester } \\
\text { Gas Cogen }\end{array}$ & Digester Gas & Internal Combustion & Cogen & San Fracisco & 2.1 \\
\hline Hunters Point & Distillate Oil & $\begin{array}{l}\text { Gas Combustion } \\
\text { Turbine,Steam Turbine }\end{array}$ & $\begin{array}{l}\text { Not } \\
\text { Cogen }\end{array}$ & San Francisco & 215 \\
\hline Usf & Natural Gas & Gas Turbine & Cogen & San Francisco & 1.5 \\
\hline Potrero & Natural Gas & Gas Turbine & Cogen & San Francisco & 362 \\
\hline $\begin{array}{l}\text { J.R. Simplot } \\
\text { Company }\end{array}$ & Waste Heat & $\begin{array}{l}\text { Steam Turbine, Waste } \\
\text { Heat/Sulfuric Acid }\end{array}$ & $\begin{array}{l}\text { Not } \\
\text { Cogen }\end{array}$ & San Joaqiun & 4 \\
\hline $\begin{array}{l}\text { Port Of Stockton } \\
\text { District Energy } \\
\text { Facility }\end{array}$ & Distillate Oil & Steam Turbine & Cogen & San Joaquin & 49.9 \\
\hline Stockton Cogen Co. & Natural Gas & $\begin{array}{l}\text { Steam Turbine, } \\
\text { W/Steam }\end{array}$ & Cogen & San Joaquin & 55.1 \\
\hline Lodi & Natural Gas & Combustion Turbine & $\begin{array}{l}\text { Not } \\
\text { Cogen }\end{array}$ & San Joaquin & 26.45 \\
\hline Gianera & Natural Gas & Combustion Turbine & $\begin{array}{l}\text { Not } \\
\text { Cogen }\end{array}$ & San Joaquin & 32.31 \\
\hline Ncpa Stig & Natural Gas & Combustion Turbine & $\begin{array}{l}\text { Not } \\
\text { Cogen }\end{array}$ & San Joaquin & 49 \\
\hline Corn Products & Natural Gas & Gas Turbine & Cogen & San Joaquin & 2.812 \\
\hline
\end{tabular}


a) Urban power plants (continued)

\begin{tabular}{|c|c|c|c|c|c|}
\hline PLANTNAME & PRIMARY FUEL & TECHNOLOGY & COGEN & COUNTY & $\begin{array}{l}\text { ONLINE } \\
\text { MW }\end{array}$ \\
\hline Byron Power Co. & Natural Gas & Gas Turbine & Cogen & San Joaquin & 6.5 \\
\hline Ripon Mill & Natural Gas & Gas Turbine & Cogen & San Joaquin & 49.5 \\
\hline Fisher Nursery & Natural Gas & & Cogen & San Joaquin & 0.1 \\
\hline Stockton Wwtp & Natural Gas & & Cogen & San Joaquin & 1.35 \\
\hline San Joaquin Cogen & Natural Gas & & Cogen & San Joaquin & 49.9 \\
\hline Gwf Tracy Peaker & Natural Gas & Brown Field & $\begin{array}{l}\text { Not } \\
\text { Cogen }\end{array}$ & San Joaquin & 169 \\
\hline Diamond Walnut & Ag. Waste & Steam Turbine, Grate & Cogen & San Joaquin & 4.5 \\
\hline Tracy Biomass Plant & Woodwaste & Steam Turbine, Grate & $\begin{array}{l}\text { Not } \\
\text { Cogen }\end{array}$ & San Joaquin & 23 \\
\hline Sri International & Natural Gas & Gas Turbine & Cogen & San Mateo & 6 \\
\hline United Cogen Inc. & Natural Gas & $\begin{array}{l}\text { Gas Turbine, Steam } \\
\text { Turbine }\end{array}$ & Cogen & San Mateo & 31 \\
\hline $\begin{array}{l}\text { Marsh Road Power } \\
\text { Plant }\end{array}$ & Landfill Gas & Reciprocating Engine & $\begin{array}{l}\text { Not } \\
\text { Cogen }\end{array}$ & San Mateo & 2 \\
\hline Ellwood & Distillate Oil & Combustion Turbine & $\begin{array}{l}\text { Not } \\
\text { Cogen }\end{array}$ & Santa Barbara & 54 \\
\hline Santa Ynez & Natural Gas & $\begin{array}{l}\text { Combustion } \\
\text { Turbine/Topping Cycle }\end{array}$ & Cogen & Santa Barbara & 49.3 \\
\hline $\begin{array}{l}\text { Santa Barbara County } \\
\text { Jail }\end{array}$ & Natural Gas & $\begin{array}{l}\text { Fuel Cell/Wasteheat } \\
\text { Recovery }\end{array}$ & Cogen & Santa Barbara & 0.2 \\
\hline Santa Maria Cogen & Natural Gas & Gas Turbine & Cogen & Santa Barbara & 9.5 \\
\hline Gaviota & Natural Gas & Gas Turbine & Cogen & Santa Barbara & 14 \\
\hline $\begin{array}{l}\text { Santa Barbara } \\
\text { Cottage Hospital }\end{array}$ & Natural Gas & & Cogen & Santa Barbara & 6.4 \\
\hline $\begin{array}{l}\text { O'brien Energy } \\
\text { Systems - Santa } \\
\text { Maria }\end{array}$ & Natural Gas & & Cogen & Santa Barbara & 43 \\
\hline
\end{tabular}


a) Urban power plants (continued)

\begin{tabular}{|c|c|c|c|c|c|}
\hline PLANTNAME & PRIMARY FUEL & TECHNOLOGY & COGEN & COUNTY & $\begin{array}{l}\text { ONLINE } \\
\text { MW }\end{array}$ \\
\hline $\begin{array}{l}\text { Southern California } \\
\text { Gas - Ucsb }\end{array}$ & Oil/Gas & $\begin{array}{l}\text { Fuel Cell/Wasteheat } \\
\text { Recovery }\end{array}$ & Cogen & Santa Barbara & 0.2 \\
\hline $\begin{array}{l}\text { Mm Tajiguas Energy } \\
\text { Llc }\end{array}$ & Landfill Gas & Reciprocating Engine & $\begin{array}{l}\text { Not } \\
\text { Cogen }\end{array}$ & Santa Barbara & 3.1 \\
\hline Gilroy Cogen & Natural Gas & Combined Cycle & Cogen & Santa Clara & 123.4 \\
\hline City Of Santa Clara & Natural Gas & $\begin{array}{l}\text { Combustion Turbine } \\
\text { With Waste Heat }\end{array}$ & Cogen & Santa Clara & 5.8 \\
\hline $\begin{array}{l}\text { San Jose Convention } \\
\text { Center }\end{array}$ & Natural Gas & Gas Turbine & Cogen & Santa Clara & 1.5 \\
\hline San Jose Cogen & Natural Gas & Gas Turbine & Cogen & Santa Clara & 6 \\
\hline Cardinal Cogen & Natural Gas & $\begin{array}{l}\text { Gas Turbine, Steam } \\
\text { Tubine }\end{array}$ & Cogen & Santa Clara & 52.9 \\
\hline Jefferson Smurfit & Natural Gas & $\begin{array}{l}\text { Gas Turbine, Steam } \\
\text { Turbine }\end{array}$ & Cogen & Santa Clara & 26.8 \\
\hline $\begin{array}{l}\text { Los Esteros Energy } \\
\text { Center }\end{array}$ & Natural Gas & Steam Turbine & $\begin{array}{l}\text { Not } \\
\text { Cogen }\end{array}$ & Santa Clara & 180 \\
\hline Agnews & Natural Gas & & Cogen & Santa Clara & 36.1 \\
\hline Gilroy Energy Center & Natural Gas & Brown Field & $\begin{array}{l}\text { Not } \\
\text { Cogen }\end{array}$ & Santa Clara & 135 \\
\hline Santa Clara & Landfill Gas & Internal Combustion & $\begin{array}{l}\text { Not } \\
\text { Cogen }\end{array}$ & Santa Clara & 1.5 \\
\hline Newby Island 2 & Landfill Gas & Recipocating Engine & $\begin{array}{l}\text { Not } \\
\text { Cogen }\end{array}$ & Santa Clara & 3.3 \\
\hline Newby Land 1 & Landfill Gas & Reciprocating Engine & $\begin{array}{l}\text { Not } \\
\text { Cogen }\end{array}$ & Santa Clara & 2 \\
\hline $\begin{array}{l}\text { Byxbee Park Sanitary } \\
\text { Landfill }\end{array}$ & Landfill Gas & Reciprocating Engine & $\begin{array}{l}\text { Not } \\
\text { Cogen }\end{array}$ & Santa Clara & 2 \\
\hline $\begin{array}{l}\text { Guadalupe Power } \\
\text { Plant }\end{array}$ & Landfill Gas & Reciprocating Engine & $\begin{array}{l}\text { Not } \\
\text { Cogen }\end{array}$ & Santa Clara & 2.6 \\
\hline Watsonville Cogen & Natural Gas & $\begin{array}{l}\text { Steam Turbine, Gas } \\
\text { Turbine }\end{array}$ & Cogen & Santa Cruz & 31 \\
\hline
\end{tabular}


a) Urban power plants (continued)

\begin{tabular}{|c|c|c|c|c|c|}
\hline PLANTNAME & PRIMARY FUEL & TECHNOLOGY & COGEN & COUNTY & $\begin{array}{l}\text { ONLINE } \\
\text { MW }\end{array}$ \\
\hline Water Street Jail & Natural Gas & & Cogen & Santa Cruz & 0.18 \\
\hline $\begin{array}{l}\text { Uc Santa Cruz Sports } \\
\text { Facility }\end{array}$ & Natural Gas & & Cogen & Santa Cruz & 0.29 \\
\hline Owl Companies & Natural Gas & & Cogen & Santa Cruz & 0.6 \\
\hline Santa Cruz Wwtp & Natural Gas & & Cogen & Santa Cruz & 0.65 \\
\hline Santa Cruz Cogen & Natural Gas & & Cogen & Santa Cruz & 2.635 \\
\hline Solano Cogen & Natural Gas & Gas Turbine & Cogen & Solano & 1.45 \\
\hline $\begin{array}{l}\text { Lambie Energy } \\
\text { Center }\end{array}$ & Natural Gas & Gas Turbine & & Solano & 48.1 \\
\hline $\begin{array}{l}\text { Wolfskill Energy } \\
\text { Center }\end{array}$ & Natural Gas & Gas Turbine & & Solano & 48.1 \\
\hline Creed Energy Center & Natural Gas & Gas Turbine & & Solano & 48.1 \\
\hline $\begin{array}{l}\text { Goose Haven Energy } \\
\text { Center }\end{array}$ & Natural Gas & Gas Turbine & & Solano & 48.1 \\
\hline $\begin{array}{l}\text { City Of Vacaville - } \\
\text { Community Center }\end{array}$ & Natural Gas & & Cogen & Solano & 0.45 \\
\hline City Of Fairfield & Natural Gas & & Cogen & Solano & 0.775 \\
\hline $\begin{array}{l}\text { California Medical } \\
\text { Facility }\end{array}$ & Natural Gas & & Cogen & Solano & 1.5 \\
\hline $\begin{array}{l}\text { Calpeak Power Vaca } \\
\text { Dixon, Llc }\end{array}$ & Natural Gas & & & Solano & 49.95 \\
\hline Valero Unit 1 \& 2 & Natural Gas & $\begin{array}{l}\text { Combustion Turbine, } \\
\text { Brown Field }\end{array}$ & $\begin{array}{l}\text { Not } \\
\text { Cogen }\end{array}$ & Solano & 47.7 \\
\hline $\begin{array}{l}\text { Laguna Plant Co-Gen } \\
\text { Facility }\end{array}$ & Natural Gas & Internal Combustion & $\begin{array}{l}\text { Not } \\
\text { Cogen }\end{array}$ & Sonoma & 2.7 \\
\hline $\begin{array}{l}\text { Central Lf (Sonoma) } \\
\text { Phase I }\end{array}$ & Landfill Gas & $\begin{array}{l}\text { Internal Combustion } \\
\text { Engine }\end{array}$ & $\begin{array}{l}\text { Not } \\
\text { Cogen }\end{array}$ & Sonoma & 3.2 \\
\hline $\begin{array}{l}\text { Central Lf (Sonoma) } \\
\text { Phase Ii }\end{array}$ & Landfill Gas & $\begin{array}{l}\text { Internal Combustion } \\
\text { Engine }\end{array}$ & $\begin{array}{l}\text { Not } \\
\text { Cogen }\end{array}$ & Sonoma & 3.2 \\
\hline
\end{tabular}


a) Urban power plants (continued)

\begin{tabular}{|c|c|c|c|c|c|}
\hline PLANTNAME & PRIMARY FUEL & TECHNOLOGY & COGEN & COUNTY & $\begin{array}{l}\text { ONLINE } \\
\text { MW }\end{array}$ \\
\hline Mcclure & Distillate Oil & Combustion Turbine & $\begin{array}{l}\text { Not } \\
\text { Cogen }\end{array}$ & Stanislaus & 117 \\
\hline Almond & Natural Gas & Combined Cycle & $\begin{array}{l}\text { Not } \\
\text { Cogen }\end{array}$ & Stanislaus & 49.5 \\
\hline Woodland I \& Ii & Natural Gas & $\begin{array}{l}\text { Combustion Turbine } \\
\text { With Waste Heat, Cc }\end{array}$ & Cogen & Stanislaus & 129.4 \\
\hline Walnut & Natural Gas & Gas-Fueled Turbine & $\begin{array}{l}\text { Not } \\
\text { Cogen }\end{array}$ & Stanislaus & 48.5 \\
\hline Hershey Chocolate & Natural Gas & Internal Combustion & Cogen & Stanislaus & 6.2 \\
\hline Modesto Energy & Msw & Steam Turbine & $\begin{array}{l}\text { Not } \\
\text { Cogen }\end{array}$ & Stanislaus & 14 \\
\hline $\begin{array}{l}\text { Stanislaus Resource } \\
\text { Recovery Facility }\end{array}$ & Msw & Steam Turbine & $\mid \begin{array}{l}\text { Not } \\
\text { Cogen }\end{array}$ & Stanislaus & 22.5 \\
\hline Sutter Power Project & Natural Gas & $\begin{array}{l}\text { Xeration, Steam To Uss- } \\
\text { Posco }\end{array}$ & $\mid \begin{array}{l}\text { Not } \\
\text { Cogen }\end{array}$ & Sutter & 540 \\
\hline $\begin{array}{l}\text { Yuba City Energy } \\
\text { Center }\end{array}$ & Natural Gas & Gas Turbine & Cogen & Sutter & 48.1 \\
\hline Yuba City Cogen & Natural Gas & Gas Turbine & Cogen & Sutter & 49 \\
\hline Greenleaf Unit Two & Natural Gas & Gas Turbine & Cogen & Sutter & 49.5 \\
\hline $\begin{array}{l}\text { Feather River Energy } \\
\text { Center }\end{array}$ & Natural Gas & Gas Turbine & & Sutter & 48.1 \\
\hline Greenleaf Unit One & Natural Gas & $\begin{array}{l}\text { Gas Turbine, Steam } \\
\text { Tubine }\end{array}$ & Cogen & Sutter & 61.4 \\
\hline Yuba City Wwtp & Natural Gas & & Cogen & Sutter & 0.14 \\
\hline Mandalay & Distillate Oil & $\begin{array}{l}\text { Steam Turbine, Gas } \\
\text { Turbine }\end{array}$ & $\begin{array}{l}\text { Not } \\
\text { Cogen }\end{array}$ & Ventura & 560 \\
\hline Camarillo Nug & Natural Gas & $\begin{array}{l}\text { Combined } \\
\text { Cycle/Topping Cycle }\end{array}$ & Cogen & Ventura & 28.04 \\
\hline Sithe Energies & Natural Gas & $\begin{array}{l}\text { Combined } \\
\text { Cycle/Topping Cycle }\end{array}$ & Cogen & Ventura & 48.5 \\
\hline
\end{tabular}


a) Urban power plants (continued)

\begin{tabular}{|c|c|c|c|c|c|}
\hline PLANTNAME & PRIMARY FUEL & TECHNOLOGY & COGEN & COUNTY & $\begin{array}{l}\text { ONLINE } \\
\text { MW }\end{array}$ \\
\hline $\begin{array}{l}\text { Us Government, } \\
\text { Naval Engineering } \\
\text { Command }\end{array}$ & Natural Gas & $\begin{array}{l}\text { Combustion } \\
\text { Turbine/Topping Cycle }\end{array}$ & Cogen & Ventura & 0.8 \\
\hline Vintage Petroleum & Natural Gas & $\begin{array}{l}\text { Combustion } \\
\text { Turbine/Topping Cycle }\end{array}$ & Cogen & Ventura & 3.3 \\
\hline Oxnard I & Natural Gas & Gas Turbine & Cogen & Ventura & 19.295 \\
\hline Hueneme Paper Mill & Natural Gas & Gas Turbine & Cogen & Ventura & 25 \\
\hline Oxnard Ii & Natural Gas & Gas Turbine & Cogen & Ventura & 49.5 \\
\hline Oxnard Wwtp & Natural Gas & $\begin{array}{l}\text { Gas Turbine Combined } \\
\text { Cycle }\end{array}$ & Cogen & Ventura & 1.5 \\
\hline Oxnard Hs & Natural Gas & $\begin{array}{l}\text { Gas-Fueled } \\
\text { Reciprocating Engine }\end{array}$ & Cogen & Ventura & 0.12 \\
\hline Doubletree Hotel & Natural Gas & $\begin{array}{l}\text { Gas-Fueled } \\
\text { Reciprocating Engine }\end{array}$ & Cogen & Ventura & 0.2 \\
\hline $\begin{array}{l}\text { City Of Ventura - } \\
\text { Eastside Wtr } \\
\text { Renovation }\end{array}$ & Natural Gas & $\begin{array}{l}\text { Gas-Fueled } \\
\text { Reciprocating Engine }\end{array}$ & Cogen & Ventura & 0.548 \\
\hline $\begin{array}{l}\text { Rockwell Intl. - } \\
\text { Kalina }\end{array}$ & Natural Gas & $\begin{array}{l}\text { Miscellaneous/Bottomin } \\
\text { g Cycle }\end{array}$ & Cogen & Ventura & 3.5 \\
\hline Rockwell Intl. & Natural Gas & $\begin{array}{l}\text { Miscellaneous/Bottomin } \\
\text { g Cycle }\end{array}$ & Cogen & Ventura & 28 \\
\hline Ormond Beach & Natural Gas & Steam Turbine & $\begin{array}{l}\text { Not } \\
\text { Cogen }\end{array}$ & Ventura & 1492 \\
\hline Unocal Rincon Cogen & Natural Gas & $\begin{array}{l}\text { Steam } \\
\text { Turbine/Enhanced Oil } \\
\text { Recovery }\end{array}$ & Cogen & Ventura & 3.5 \\
\hline Oxnard & Landfill Gas & Internal Combustion & $\begin{array}{l}\text { Not } \\
\text { Cogen }\end{array}$ & Ventura & 5.55 \\
\hline UCDavis & Natural Gas & Gas Turbine & Cogen & Yolo & 3 \\
\hline $\begin{array}{l}\text { Woodland Biomass } \\
\text { Power Ltd }\end{array}$ & $\begin{array}{l}\text { Ag. \& } \\
\text { Woodwaste }\end{array}$ & Steam Turbine & $\begin{array}{l}\text { Not } \\
\text { Cogen }\end{array}$ & Yolo & 28 \\
\hline
\end{tabular}


a) Urban power plants (continued)

\begin{tabular}{|l|l|l|l|l|c|}
\hline PLANTNAME & PRIMARY FUEL & TECHNOLOGY & COGEN & COUNTY & $\begin{array}{c}\text { ONLINE } \\
\text { MW }\end{array}$ \\
\hline \hline $\begin{array}{l}\text { Mm Yolo Power LLC } \\
\text { Facility }\end{array}$ & Landfill Gas & Reciprocating Engine & $\begin{array}{l}\text { Not } \\
\text { Cogen }\end{array}$ & Yolo & 2.85 \\
\hline
\end{tabular}


b) Rural power plants

\begin{tabular}{|c|c|c|c|c|c|}
\hline PLANTNAME & $\begin{array}{l}\text { PRIMARY } \\
\text { FUEL }\end{array}$ & TECHNOLOGY & COGEN & COUNTY & $\begin{array}{c}\text { ONLINE } \\
\text { MW }\end{array}$ \\
\hline $\begin{array}{l}\text { Jackson Valley } \\
\text { Energy Lp }\end{array}$ & Lignite Coal & Steam Turbine & Cogen & Amador & 17.99 \\
\hline $\begin{array}{l}\text { Mule Creek State } \\
\text { Prison }\end{array}$ & Natural Gas & Internal Combustion & Cogen & Amador & 3 \\
\hline $\begin{array}{l}\text { Wheelabrator Martell } \\
\text { Inc. }\end{array}$ & Woodwaste & Steam Turbine & Cogen & Amador & 18 \\
\hline Wadham & Rice By Products & Steam Turbine & $\begin{array}{l}\text { Not } \\
\text { Cogen }\end{array}$ & Colusa & 29.5 \\
\hline Csu Humboldt & Natural Gas & & 0 Cogen & Humboldt & 0.35 \\
\hline $\begin{array}{l}\text { Samoa Pacific } \\
\text { Cellulose, Llc }\end{array}$ & Natural Gas & Steam Turbine & Cogen & Humboldt & 20 \\
\hline Pacific Lumber Co. & Woodwaste & Steam Turbine & Cogen & Humboldt & 32.5 \\
\hline $\begin{array}{l}\text { Ultrapower } 3 \text { Blue } \\
\text { Lake }\end{array}$ & Woodwaste & Steam Turbine & $\begin{array}{l}\text { Not } \\
\text { Cogen }\end{array}$ & Humboldt & 13.806 \\
\hline Farihaven Power Co. & Woodwaste & Steam Turbine & $\begin{array}{l}\text { Not } \\
\text { Cogen }\end{array}$ & Humboldt & 15 \\
\hline Brawley & Distillate Oil & Combustion Turbine & $\begin{array}{l}\text { Not } \\
\text { Cogen }\end{array}$ & Imperial & 20 \\
\hline Rockwood & Natural Gas & Combustion Turbine & $\begin{array}{l}\text { Not } \\
\text { Cogen }\end{array}$ & Imperial & 46 \\
\hline El Centro & Natural Gas & $\begin{array}{l}\text { Steam Turbine, } \\
\text { Combined Cycle }\end{array}$ & $\begin{array}{l}\text { Not } \\
\text { Cogen }\end{array}$ & Imperial & 80 \\
\hline $\begin{array}{l}\text { Mesquite Resource } \\
\text { Recovery Project }\end{array}$ & $\begin{array}{l}\text { Ag. \& Animal } \\
\text { Waste }\end{array}$ & Steam Turbine, Grate & $\begin{array}{l}\text { Not } \\
\text { Cogen }\end{array}$ & Imperial & 17.89 \\
\hline Rio Bravo Poso & Coal & Steam Turbine & Cogen & Kern & 33 \\
\hline Rio Bravo Jasmin & Petroleum Coke & Steam Turbine & Cogen & Kern & 33 \\
\hline $\begin{array}{l}\text { Mt. Poso } \\
\text { Cogeneration }\end{array}$ & Natural Gas/Eor & Steam Turbine & Cogen & Kern & 63.64 \\
\hline
\end{tabular}


b) rural power plants (continued)

\begin{tabular}{|c|c|c|c|c|c|}
\hline PLANTNAME & PRIMARY FÜEL & TECHNOLOGY & COGEN & COUNTY & $\begin{array}{l}\text { ONLINE } \\
\text { MW }\end{array}$ \\
\hline $\begin{array}{l}\text { La Paloma } \\
\text { Generating Project }\end{array}$ & Natural Gas & Combined Cycle & $\begin{array}{l}\text { Not } \\
\text { Cogen }\end{array}$ & Kern & 968 \\
\hline Sunrise Power Project & Natural Gas & $\begin{array}{l}\text { Fired Cogeneration (For } \\
\text { Teor) }\end{array}$ & Cogen & Kern & 320 \\
\hline Arco-Fee "B" & Natural Gas & Gas Turbine & Cogen & Kern & 3.725 \\
\hline Welport Project & Natural Gas & Gas Turbine & Cogen & Kern & 3.8 \\
\hline Frito-Lay & Natural Gas & Gas Turbine & Cogen & Kern & 6 \\
\hline Dome Project & Natural Gas & Gas Turbine & Cogen & Kern & 6.6 \\
\hline Arco - Fee "C" & Natural Gas & Gas Turbine & Cogen & Kern & 7.45 \\
\hline Arco - Fee "A" & Natural Gas & Gas Turbine & Cogen & Kern & 7.925 \\
\hline Texaco - Mckittrick & Natural Gas & Gas Turbine & Cogen & Kern & 10.969 \\
\hline North Midway & Natural Gas & Gas Turbine & Cogen & Kern & 10.97 \\
\hline Chevron - Taft & Natural Gas & Gas Turbine & Cogen & Kern & 12.5 \\
\hline Chevron Cymric & Natural Gas & Gas Turbine & Cogen & Kern & 26.3 \\
\hline Dai/Oildale Cogen & Natural Gas & Gas Turbine & Cogen & Kern & 31 \\
\hline $\begin{array}{l}\text { Berry Cogen - } \\
\text { Midway Sunset }\end{array}$ & Natural Gas & Gas Turbine & Cogen & Kern & 38.7 \\
\hline Midset Cogen & Natural Gas & Gas Turbine & Cogen & Kern & 39 \\
\hline Oildale Cogen & Natural Gas & Gas Turbine & Cogen & Kern & 40 \\
\hline Boron & Natural Gas & Gas Turbine & Cogen & Kern & 45 \\
\hline Chalk Cliff Cogen & Natural Gas & Gas Turbine & Cogen & Kern & 47 \\
\hline Badger Creek Ltd. & Natural Gas & Gas Turbine & Cogen & Kern & 47 \\
\hline South Belridge Cogen & Natural Gas & Gas Turbine & Cogen & Kern & 48 \\
\hline Double "C" Ltd. & Natural Gas & Gas Turbine & Cogen & Kern & 53.6 \\
\hline High Sierra Ltd. & Natural Gas & Gas Turbine & Cogen & Kern & 53.6 \\
\hline Kern Front Ltd. & Natural Gas & Gas Turbine & Cogen & Kern & 53.6 \\
\hline
\end{tabular}


b) rural power plants (continued)

\begin{tabular}{|c|c|c|c|c|c|}
\hline PLANTNAME & PRIMARY FUEL & TECHNOLOGY & COGEN & COUNTY & $\begin{array}{l}\text { ONLINE } \\
\text { MW }\end{array}$ \\
\hline Bear Mountain Ltd. & Natural Gas & Gas Turbine & Cogen & Kern & 68.82 \\
\hline Live Oak Cogen & Natural Gas & Gas Turbine & Cogen & Kern & 68.82 \\
\hline Mckittrick Cogen & Natural Gas & Gas Turbine & Cogen & Kern & 72 \\
\hline Kern River Cogen & Natural Gas & Gas Turbine & Cogen & Kern & 300 \\
\hline Sycamore Cogen & Natural Gas & Gas Turbne & Cogen & Kern & 300 \\
\hline Elk Hills & Natural Gas & Gas Turbine & $\begin{array}{l}\text { Not } \\
\text { Cogen }\end{array}$ & Kern & 500 \\
\hline Mohave Cogen & Natural Gas & $\begin{array}{l}\text { Gas Turbine, Stesm } \\
\text { Turbine }\end{array}$ & Cogen & Kern & 56.4 \\
\hline M.H. Whittier Cal & Natural Gas & 0 & Cogen & Kern & 0.5 \\
\hline $\begin{array}{l}\text { Cal Resources - N. } \\
\text { Midway Sunset }\end{array}$ & Natural Gas & 0 & olCogen & Kern & 4.25 \\
\hline Arco Oxford & Natural Gas & 0 & olCogen & Kern & 5.2 \\
\hline $\begin{array}{l}\text { Occidental Of Elk } \\
\text { Hills Inc. }\end{array}$ & Natural Gas & 0 & Cogen & Kern & 10 \\
\hline Lost Hills & Natural Gas & 0 & 0 Cogen & Kern & 10.969 \\
\hline Berry Petroleum Co. & Natural Gas & 0 & ologen & Kern & 17 \\
\hline Midsun Partners & Natural Gas & 0 & Cogen & Kern & 27.35 \\
\hline Sekr Cogen & Natural Gas & 0 & OCogen & Kern & 34.468 \\
\hline $\begin{array}{l}\text { Chevron - Kern River } \\
\text { Eastridge }\end{array}$ & Natural Gas & 0 & Cogen & Kern & 44 \\
\hline $\begin{array}{l}\text { Sunrise Ii Combined } \\
\text { Cycle Expansion }\end{array}$ & Natural Gas & & $0 \mid \begin{array}{l}\text { Not } \\
\text { Cogen }\end{array}$ & Kern & 265 \\
\hline $\begin{array}{l}\text { Midway-Sunset } \\
\text { Cogen }\end{array}$ & Natural Gas/Eor & Gas Turbine & Cogen & Kern & 242 \\
\hline $\begin{array}{l}\text { Delano Energy Co. } \\
\text { Inc. }\end{array}$ & $\begin{array}{l}\text { Ag. \& } \\
\text { Woodwaste }\end{array}$ & Agricultural Waste & $\begin{array}{l}\text { Not } \\
\text { Cogen }\end{array}$ & Kern & 56.5 \\
\hline Spi-Susanville & Woodwaste & Steam Turbine & Cogen & Lassen & 14.34 \\
\hline Mt. Lassen Power & Woodwaste & Steam Turbne & Cogen & Lassen & 11.4 \\
\hline
\end{tabular}


b) rural power plants (continued)

\begin{tabular}{|c|c|c|c|c|c|}
\hline PLANTNAME & PRIMARY FUEL & TECHNOLOGY & COGEN & COUNTY & $\begin{array}{l}\text { ONLINE } \\
\text { MW }\end{array}$ \\
\hline $\begin{array}{l}\text { Big Valley Lumber } \\
\text { Co. }\end{array}$ & Woodwaste & Steam Turbine, $\mathrm{W} /$ Steam & Cogen & Lassen & 7.5 \\
\hline Hi Power Co. & Woodwaste & 0 & Cogen & Lassen & 35.5 \\
\hline Heublein Wines & Natural Gas & 0 & Cogen & Madera & 0.325 \\
\hline $\begin{array}{l}\text { Fort Bragg Western } \\
\text { Wood Products }\end{array}$ & Woodwaste & & $\begin{array}{l}\text { Not } \\
\text { Cogen }\end{array}$ & Mendocino & 15 \\
\hline Portola & Diesel & Internal Combustion & $\begin{array}{l}\text { Not } \\
\text { Cogen }\end{array}$ & Plumas & 5.7 \\
\hline $\begin{array}{l}\text { Collins Pine Co. } \\
\text { Project }\end{array}$ & Woodwaste & Steam Turbine & Cogen & Plumas & 12 \\
\hline Spi-Quincy & Woodwaste & Steam Turbine & Cogen & Plumas & 27.5 \\
\hline Morro Bay & Natural Gas & Steam Turbine & \begin{tabular}{|l|} 
Not \\
Cogen
\end{tabular} & $\begin{array}{l}\text { San Luis } \\
\text { Obispo }\end{array}$ & 1021 \\
\hline Koch California Ltd. & Natural Gas & & Cogen & $\begin{array}{l}\text { San Luis } \\
\text { Obispo }\end{array}$ & 0.3 \\
\hline Lassen Energy & Natural Gas & Gas Turbine & Cogen & Shasta & 38.8 \\
\hline Redding Power & Natural Gas & $\begin{array}{l}\text { Steam Turbine \& } \\
\text { Combustion Turbines }\end{array}$ & $\begin{array}{l}\text { Not } \\
\text { Cogen }\end{array}$ & Shasta & 97.2 \\
\hline City Of Redding & Natural Gas & & Cogen & Shasta & 28 \\
\hline Spi- Anderson & Woodwaste & Fuel Cell Gasification & Cogen & Shasta & 4 \\
\hline $\begin{array}{l}\text { Wheelabator Hudson } \\
\text { Energy }\end{array}$ & Woodwaste & Steam Turbine & Cogen & Shasta & 6.8 \\
\hline $\begin{array}{l}\text { Burney Mountain } \\
\text { Power }\end{array}$ & Woodwaste & Steam Turbine & Cogen & Shasta & 11.4 \\
\hline Spi-Burney & Woodwaste & Steam Turbine & Cogen & Shasta & 20 \\
\hline $\begin{array}{l}\text { Burney Forest } \\
\text { Products }\end{array}$ & Woodwaste & Steam Turbine & Cogen & Shasta & 31 \\
\hline Wheelabrator Shasta & Woodwaste & Steam Turbine & Cogen & Shasta & 62.75 \\
\hline Downieville & Diesel & Combustion Turbine & \begin{tabular}{|l|} 
Not \\
Cogen
\end{tabular} & Sierra & 0.7 \\
\hline
\end{tabular}


b) rural power plants (continued)

\begin{tabular}{|c|c|c|c|c|c|}
\hline PLANTNAME & PRIMARY FUEL & TECHNOLOGY & COGEN & COUNTY & $\begin{array}{l}\text { ONLINE } \\
\text { MW }\end{array}$ \\
\hline Spi- Loyalton & Woodwaste & Steam Turbine & Cogen & Sierra & 20 \\
\hline $\begin{array}{l}\text { Tulare Detention } \\
\text { Facility }\end{array}$ & Natural Gas & $\begin{array}{l}\text { Gas Fueled Reciprocating } \\
\text { Engine }\end{array}$ & Cogen & Tulare & 0.55 \\
\hline Kaweah Hospital & Natural Gas & Gas Turbine & Cogen & Tulare & 1 \\
\hline $\begin{array}{l}\text { Mm Tulare Energy } \\
\text { Llc }\end{array}$ & Landfill Gas & $\begin{array}{l}\text { Gas Turbine Combined } \\
\text { Cycle }\end{array}$ & $\begin{array}{l}\text { Not } \\
\text { Cogen }\end{array}$ & Tulare & 1.8 \\
\hline $\begin{array}{l}\text { Pacific Ultrapower } \\
\text { Chinese Station }\end{array}$ & Woodwaste & Steam Turbine & $\begin{array}{l}\text { Not } \\
\text { Cogen }\end{array}$ & Tuolumne & 25 \\
\hline Spi-Sonora & Woodwaste & Traveling Grate & Cogen & Tuolumne & 7.5 \\
\hline
\end{tabular}


